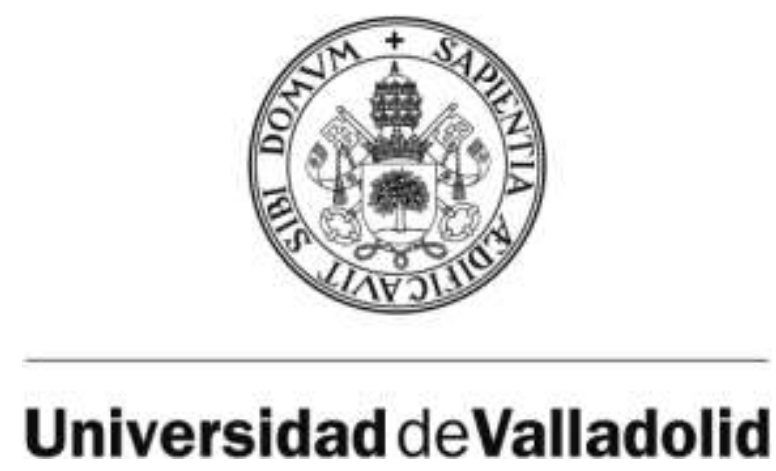

ESCUELA TÉCNICA SUPERIOR DE INGENIERÍAS AGRARIAS

DEPARTAMENTO DE PRODUCCIÓN VEGETAL Y RECURSOS FORESTALES

TESIS DOCTORAL:

\title{
UTILIZACIÓN DE AGENTES DE ABSCISIÓN DE LA UVA PARA OPTIMIZAR LA VENDIMIA MECANIZADA
}

Presentada por Lorena Uzquiza Ollauri para optar al grado de doctora por la Universidad de Valladolid

Dirigida por:

Pedro Martín Peña 
Esta Tesis Doctoral ha sido posible gracias al disfrute por parte de la autora de una Ayuda para la Formación de Personal Investigador de la Universidad de Valladolid (convocatoria de 2010), desde el 30 de Julio de 2010 hasta el 29 de Julio 2014, financiada por la Universidad de Valladolid y el Banco Santander.

EL trabajo se ha realizado en colaboración con la empresa Bodegas José Pariente S.L. y ha sido financiado por el Centro para el Desarrollo Tecnológico Industrial con el Proyecto de investigación: IDI20111241 (Fondos FEDER de la Unión Europea). 



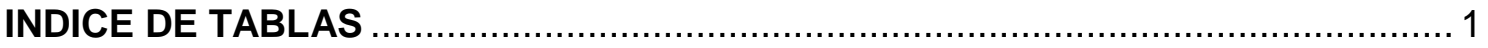

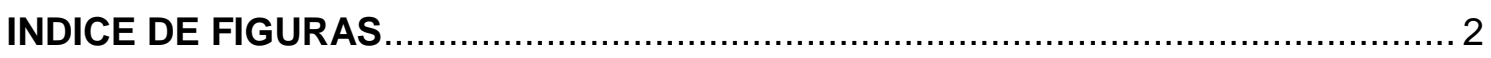

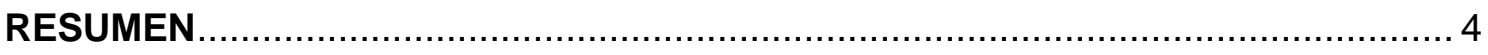

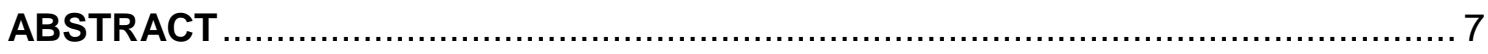

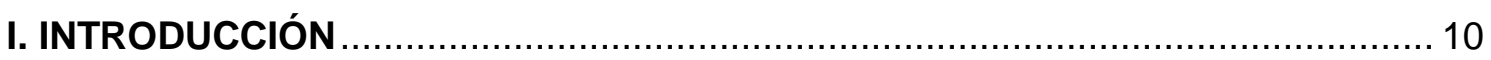

I.1. La vendimia mecanizada...................................................................... 10

I.1.1. Factores de calidad del proceso de vendimia mecanizada........................ 11

I.1.1.1. Pérdidas del producto................................................................. 11

I.1.1.2. Daños provocados a las plantas. .................................................. 12

I.1.1.3. Calidad de la cosecha. ............................................................. 13

I.1.2. Técnicas para optimizar la calidad de uva vendimiada mecánicamente...... 15

I.2. La abscisión de los frutos....................................................................... 17

I.2.1 El proceso fisiológico de la abscisión. ................................................. 17

I.2.2 Regulación hormonal de la abscisión..................................................... 19

I.3. Utilización de fitorreguladores para favorecer el proceso de abscisión de los

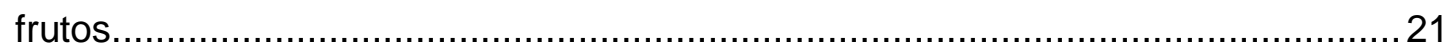

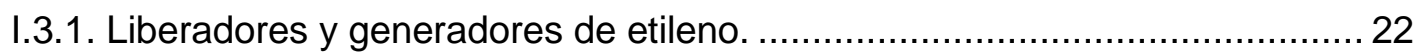

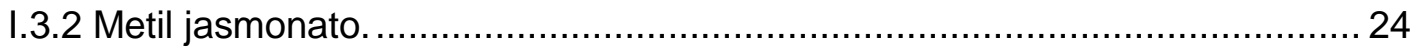

II. OBJETIVOS Y PLANTEAMIENTO EXPERIMENTAL.......................................29

III. ENSAYO 1.Potential of combined ethephon and methyl jasmonate treatments for improving mechanical harvesting of wine grapes.(Potencialidad de los tratamientos combinados de etefón y metil jasmonato para mejorar la vendimia

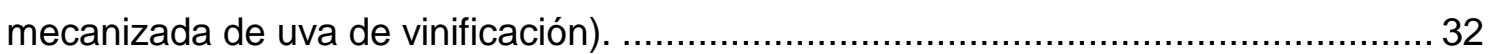

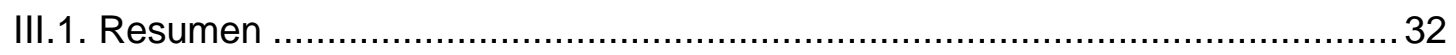

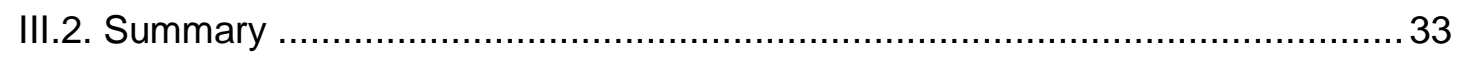

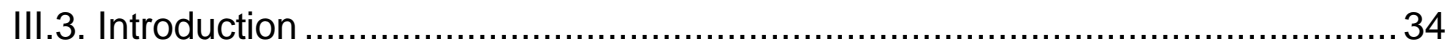

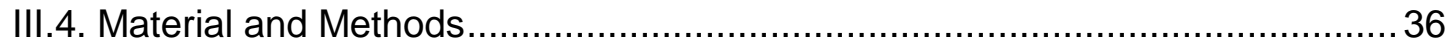

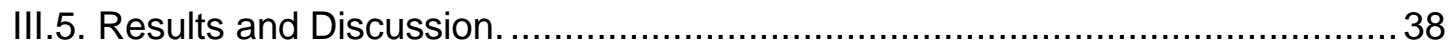

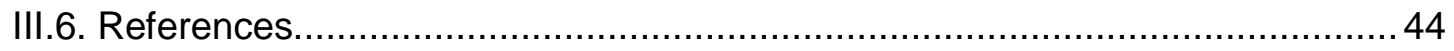

IV. ENSAYO 2.Methyl Jasmonate and 1-Aminocyclopropane-1-Carboxylic Acid Interact to Promote Grape Berry Abscission.(Metil jasmonato y ácido 1aminociclopropano-1-carboxilico interactuan para promover la abscisión de uva)......48

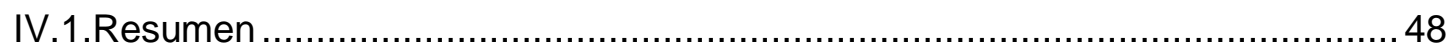

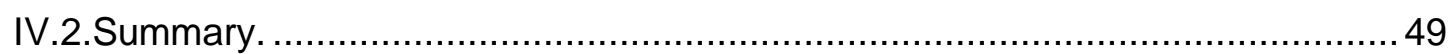

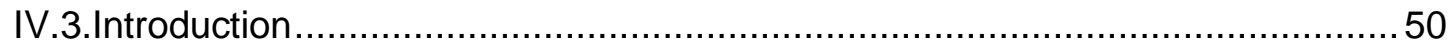

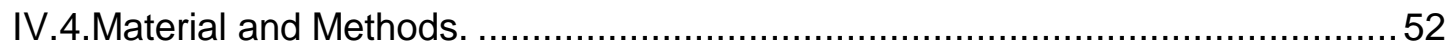

IV.4.1. Location and vineyard characteristics. ............................................. 52 


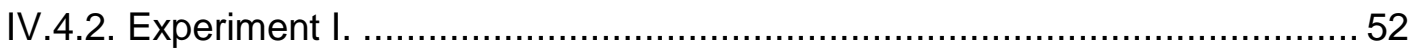

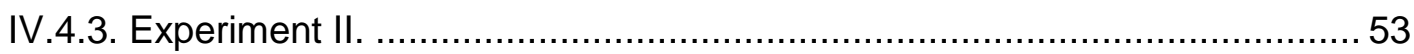

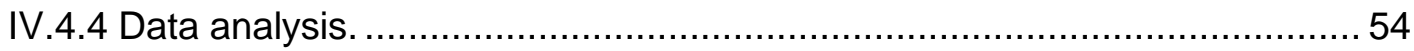

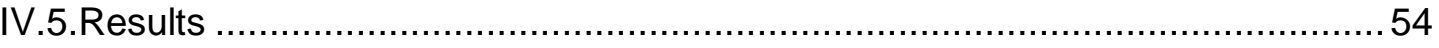

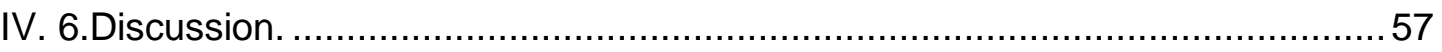

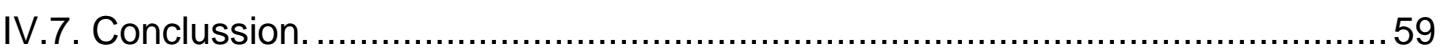

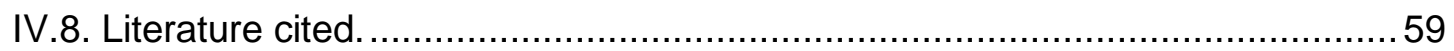

V. ENSAYO 3.A preharvest treatment of ethephon and methyl jasmonate affect mechanical harvesting performance and composition of 'Verdejo' grapes and wines.(Un tratamiento prevendimia de etefón y metil jasmonatos afecta al rendimiento de la vendimia mecanizada y a la composición de uvas y vino 'Verdejo').62

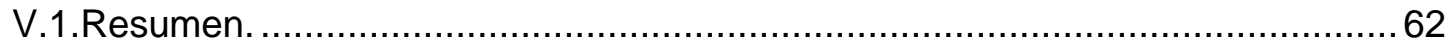

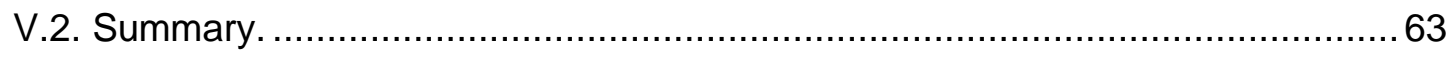

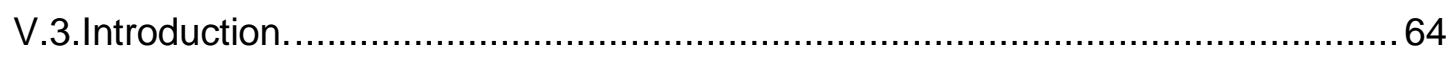

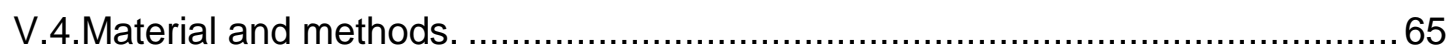

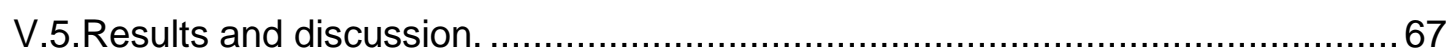

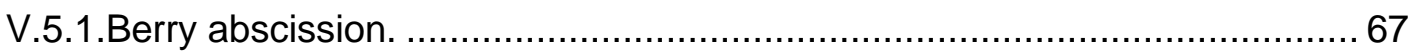

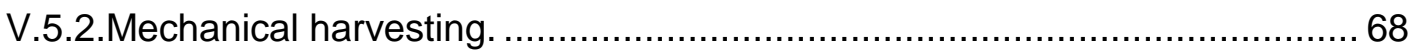

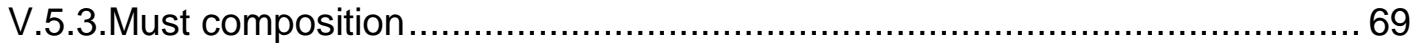

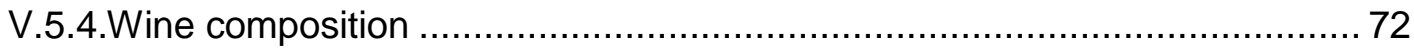

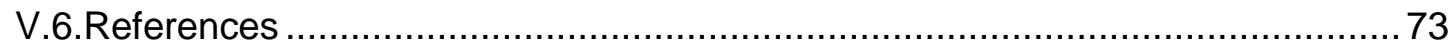

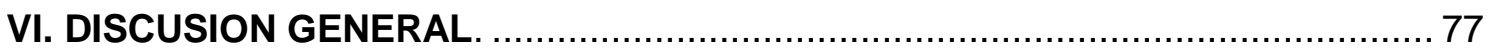

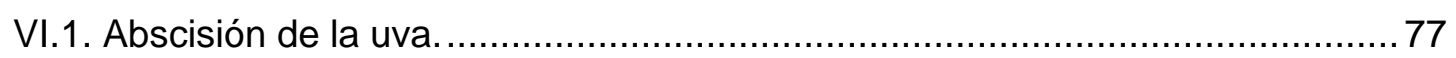

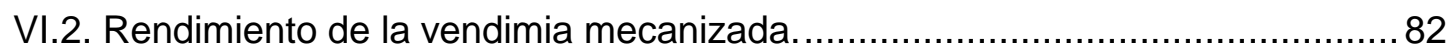

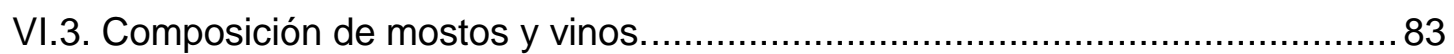

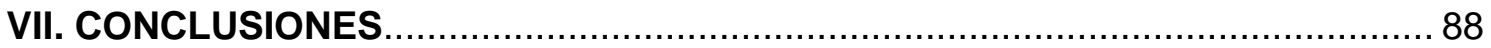

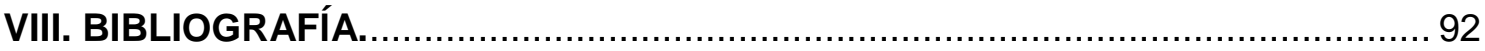




\section{INDICE DE TABLAS}

Table III.1. Mean squares of factorial analysis of variance of data obtained from ethephon (ET) and methyl jasmonate (MJ) sprayings at different days after treatments (DAT) in 2009, 2010 and 2011

Table III.2. Mean values of fruit detachment force and proportion of abscised berries exhibiting a dry stem scar, obtained with ethephon (ET) and methyl jasmonate (MJ) applications in different days after treatments (DAT)

Table IV.1. Effect of 1-aminocyclopropane-1-carboxylate (ACC) and methyl jasmonate (MeJA) on fruit detachment force of Thompson Seedless grapes three days after treatment in 2010

Table IV.2. Effect of 1-aminocyclopropane-1-carboxylate (ACC) and methyl jasmonate (MeJA) on fruit detachment force of Thompson Seedless grapes at different intervals following treatment in 2013.

Table IV.3. Effect of methyl jasmonate (MeJA) and 1-aminocyclopropane-1carboxylate (ACC) on berry abscission of Thompson Seedless grapes in $2013 \ldots$

Table V.1. F values of factorial analysis of variance of grape and wine composition data, obtained with different preharvest treatment (TR: application of ethephon plus methyl jasmonate versus control) and harvest method (HM: hand picking versus mechanical) in 2011 and 2013.

Table V.2. Effect of the preharvest treatment with ethephon plus methyl jasmonate on must and wine composition. 


\section{INDICE DE FIGURAS}

Figura I.1. Modelo del equilibrio de fitorreguladores en abscisión.

Figura I.2. Uva sin cicatriz (izquierda) y uva con cicatriz (derecha) en la zona de abscisión.

Figura I.3. Molécula de metil jasmonato.

Figure III.1. Comparison of means of fruit detachment force (FDF) registered 4 days after applications in plants treated and untreated with ethephon (ET) in 2009, 2010 and 2011.

Figure III.2. Percentage of detached berries presenting scar tissue in the abscission zone, when the clusters were shaken by hand at harvest, in different experimental treatments combining ethephon (ET) and methyl jasmonate (MJ) applications

Figure III.3. Effect of different doses of methyl jasmonate on total acidity of must in the three years studied

Figure IV.1. Effect of treatments of $1,000 \mathrm{mg} / \mathrm{L}$ 1-aminocyclopropane- 1carboxylate (ACC), 1,344 mg/L methyl jasmonate (MeJA), and their combination on ethylene production by Thompson Seedless grapes on several days after treatment in 2013

Figure IV.2. Effect of 1-aminocyclopropane-1-carboxylate (ACC) and methyl jasmonate (MeJA) on the percentage of Thompson Seedless grape berries with dry stem scars after detachment on several days after treatment in 2013. (A) The effect of MeJA on grapes with $0 \mathrm{mg} / \mathrm{L} \mathrm{ACC}$, and $(B)$ the effect of MeJA on grapes with $1000 \mathrm{mg} / \mathrm{L} \mathrm{ACC}$

Figure V.1. Influence of the preharvest treatment with ethephon plus methyl jasmonate $(\mathrm{ET}+\mathrm{MJA})$ and shaking frequencies on weight percentage of product losses registered during mechanical harvesting in 2011 and 2013.

Figure V.2. Effects of the preharvest application with ethephon plus methyl jasmonate and type of harvest on total soluble solid content of the must (TSS) 


\section{RESUMEN}




\section{RESUMEN}

La mecanización de la vendimia constituye una oportunidad de reducir los costes del cultivo de viñedo, a la vez que reduce el tiempo de ejecución, lo cual permite ajustarse mejor al óptimo de madurez de la uva. El proceso de vendimia mecanizada produce daños mecánicos sobre las uvas y libera mosto susceptible de ser oxidado, pudiendo provocar maceraciones o fermentaciones incontroladas, que afectarían negativamente la calidad del vino. La aplicación en prevendimia de agentes de abscisiones sobre los racimos podría facilitar el desprendimiento de la uva, posibilitando la mecanización de la vendimia con unos regímenes de trabajo menos enérgicos, que minimizaran los daños provocados a los frutos y la liberación de mosto. En la presente Tesis Doctoral se ha estudiado el potencial interés de la aplicación en prevendimia de diferentes agentes de abscisión de la uva como técnica para facilitar la recolección mecanizada y obtener mostos y vinos de mayor calidad.

Se plantearon tres ensayos de campo que se desarrollaron entre 2009 y 2013: dos en uva de vinificación cv. Verdejo en la D.O Rueda, España (Ensayos 1 y 3), y uno en uva de pasificación cv. Thompson seedless en Parlier, California (Ensayo 2). Se ha estudiado la influencia de la pulverización de MeJA a distintas dosis (desde 672 a $8960 \mathrm{mg} \cdot \mathrm{L}^{-1}$ ) sobre la fuerza de desprendimiento del fruto, la presencia de tejido cicatricial en la zona de abscisión y la caída prematura de frutos en cv. Verdejo y cv. Thompson seedless (Ensayos 1 y 2 respectivamente), evaluándose también los efectos aditivos y de interacción de MeJA con etefón (Ensayo 1) y con ácido 1 aminociclopropano-1-carboxílico (ACC) (Ensayo 2). Finalmente, en el Ensayo 3 se estudió la influencia de los tratamientos combinados de $1000 \mathrm{mg} \cdot \mathrm{L}^{-1}$ de etefón más $8960 \mathrm{mg} \cdot \mathrm{L}^{-1}$ de MeJA en el rendimiento y calidad de la vendimia manual y mecanizada con diferentes regímenes de sacudido (400 y 425 golpes $\cdot \mathrm{min}^{-1}$ ), determinando el porcentaje de mosteo, las pérdidas de producto, los parámetros de composición de mostos y vinos, y la estabilidad oxidativa del vino.

Las aplicaciones individuales de MeJA, etefón o ACC unos días antes de la recolección redujeron la fuerza de desprendimiento del fruto, observándose que MeJA y ACC promovían la cicatrización de la zona de abscisión de las bayas frente a los testigos sin tratar. La combinación de MeJA con etefón o ACC ha mostrado efectos aditivos y sinérgicos sobre diferentes parámetros relacionados con la abscisión del fruto. La aplicación de MeJA combinado con ACC en cv. Thompson seedless dio lugar a una caída prematura de uva que supuso una pérdida significativa de cosecha frente a los controles. Sin embargo, en uva cv. Verdejo, la aplicación de agentes de abscisión 
no supuso problema alguno de caída de frutos, defoliación, ni retrasos en la brotación de las yemas en el ciclo siguiente.

La producción endógena de etileno en los tejidos del fruto cv. Thompson seedless se incrementó significativamente con tratamientos de ACC, observándose una interacción positiva con la aplicación de MeJA.

En el Ensayo 3 se ha observado que la aplicación combinada de MeJA y etefón permitió reducir la liberación de mosto durante la vendimia mecanizada, cuando se trabajaba con una frecuencia de sacudido de 425 golpes $\mathrm{min}^{-1}$, si bien las pérdidas de cosecha debidas a las uvas caídas al suelo durante la operación se incrementaron frente a los controles sin tratar. Los resultados encontrados con frecuencia de 400 golpes $\cdot \min ^{-1}$ no fueron significativamente distintos de los controles.

Los mostos procedentes de racimos tratados con etefón y MeJA no presentaron cambios en el $\mathrm{pH}$ o la acidez total frente a los controles, pero si un menor contenido de potasio y un incremento de la cantidad de ácidos cinamiltartáricos presentes. Los tratamientos incrementaron el contenido de polifenoles totales de mostos y vinos, pero no modificaron significativamente el color ni la estabilidad oxidativa de los vinos.

Los resultados obtenidos confirman el interés del etefón, MeJA y ACC como agentes de abscisión del fruto en la vid, y ponen de manifiesto la utilidad potencial de las aplicaciones combinadas de MeJA y etefón para mejorar la calidad de la uva de vinificación vendimiada mecánicamente. 
ABSTRACT 


\section{ABSTRACT}

Grape harvest mechanization is an opportunity to reduce vineyard costs, and at the same time, it reduces the time spent on it, which allows to adjust better to the optimal grape maturity. Mechanical harvesting process produces mechanical damages to the grapes and releases must which can be oxidized and produce macerations or uncontrolled fermentations, affecting negatively wine quality. The preharvest application of abscission agents over the clusters could ease the detachment of the grapes, enabling harvesting at less energetic shaking frequencies, which minimize the damages to the fruits and the release of must. In this PhD Thesis, it has been studied the potential interest of the preharvest application of different grape abscission agents as a technique to ease the mechanical harvesting and to obtain musts and wines of higher quality.

Three field experiments were designed and performed between 2009 and 2013: two trials with wine grape cv. Verdejo in Appellation d'Origine Rueda, Spain (Trial 1 and Trial 3), and one trial in raising grape cv. Thompson seedless in Parlier, California (Trial 2). It has been studied the effect of methyl jasmonate (MeJA) sprayed at different doses (from 672 to $8960 \mathrm{mg} \cdot \mathrm{L}^{-1}$ ) on the fruit detachment force, the presence of a scar tissue in the abscission zone and the fruits dropping before harvest in cv. Verdejo and cv. Thomposon seedless (Trial 1 and 2, respectively), also evaluating the additive and the interaction effects of MeJA with ethephon (Trial 1) or 1-aminocyclopropane-1carboxylic acid (ACC) (Trial 2). Finally, in Test 3 it was study the influence of combined treatments of $1000 \mathrm{mg} \cdot \mathrm{L}^{-1}$ of ethephon plus $8960 \mathrm{mg} \cdot \mathrm{L}^{-1}$ of MeJA in the performance and quality of manual and mechanical harvesting at different shaking frequencies (400 and 425 shakes $\min ^{-1}$ ), determining the percentage of released must, the composition parameters of musts and wines, and the oxidative stability of the wine.

Single application of MeJA, ethephon or ACC some days before the harvesting reduced the fruit detachment force, observing that MeJA and ACC promoted a scar tissue in the abscission zone of grapes comparing to untreated controls. The combination of MeJA with ethephon or ACC has showed additive and synergistic effects on different parameters related to fruit abscission. The application of MeJA combined with ACC in cv. Thompson seedless caused a premature grape drop that was a significant yield loss comparing to the controls. Nevertheless, in grapes cv. Verdejo, the application of abscission agents did not suppose problems related to grape dropping, defoliation, or delay of budbreak the next cycle. 
The endogenous ethylene production in the tissues of grapes cv. Thompson seedless increased significantly with ACC treatment, presenting a positive interaction with the application of MeJA.

In Trial 3 it has been observed that the combined application of MeJA and ethephon reduced the release of must during the mechanical harvesting, if realized at a frequency of 425 shakes $\mathrm{min}^{-1}$, although the product losses due to the drop of grapes during the process were increased compared to untreated controls. Results at a frequency of 400 shakes $\cdot \min ^{-1}$ were not significantly different from controls.

Musts from clusters co-treated with ethephon and MeJA did not show changes in $\mathrm{pH}$ or total acidity comparing to controls, but did show a lower potassium content and an increase of the concentration of hydroxycinnamic acids. The treatments increased the polyphenol content of must and wines, but did not affect significantly neither the color nor the oxidative stability of wines.

The obtained results confirm the interest of ethephon, MeJA and ACC as fruit abscission agents in grapevines, and showed up the potential of the combined applications of MeJA and ethephon to improve the quality of mechanically harvested wine grape. 
I.INTRODUCCIÓN 


\section{INTRODUCCIÓN}

\section{I.1. La vendimia mecanizada.}

La vendimia es la operación que requiere más cantidad de mano de obra en el cultivo del viñedo, superando a la poda anual (Hidalgo, 1993). Ante la necesidad de buscar una alternativa a la vendimia manual para hacer más competitivas las explotaciones vitivinícolas, surgieron los primeros estudios sobre la vendimia mecanizada en Estados Unidos, realizándose la primera vendimia mecanizada experimental en California a principios de la década de los cincuenta del siglo pasado (Intrieri, 2013). Los mayores avances desarrollados en vendimiadoras se incorporaron entre principios y mediados de la década de los sesenta, y la mecanización de la vendimia empezó a nivel comercial a finales de esa década. La técnica fue desarrollada paralelamente en Europa, pero la vendimia mecanizada no comenzó a implantarse en España hasta principios de los noventa. Este retraso se debió a razones diversas, como los bajos rendimientos, la falta de adaptación de los sistemas de conducción del viñedo, la mayor disponibilidad de mano de obra para realizar la vendimia manual y la desconfianza inicial sobre el trabajo efectuado por las máquinas vendimiadoras (Ortiz-Cañavete et al., 1995). Hoy en día la recolección mecanizada está muy extendida en el sector vitivinícola español con 1980 máquinas registradas al finalizar 2014 (MAGRAMA, 2015).

La mecanización permite reducir los costes de la vendimia aproximadamente el $35 \%$ respecto a la recogida manual (Pipitone et al., 2003), ya que una hora de trabajo de vendimia mecanizada equivale al trabajo de una cuadrilla de diez personas en una jornada completa (Pezzi et al., 2008). Además de la reducción de costes, la vendimia mecanizada presenta ventajas importantes frente a la recolección manual como la rapidez de su ejecución o la posibilidad de realizarse por la noche, a temperaturas bajas, pudiendo esto permitir la recogida de los frutos en su momento óptimo de madurez y en condiciones ambientales que eviten procesos de oxidación incontrolados que pueden perjudicar la calidad del producto.

El principal inconveniente de la vendimia mecanizada es que con ella no se obtienen racimos enteros, sino proporciones de los mismos y bayas sueltas, que pueden quedar rotas y liberar mosto. Esto favorece el desarrollo de procesos bioquímicos de oxidación que pueden afectar negativamente a las características físico-químicas y organolépticas del mosto y del vino (Nagel y Graber, 1988). El problema puede verse acentuado al incrementarse el intervalo de tiempo que 
transcurre entre la vendimia y el procesado en la bodega, y cuando la temperatura ambiente es alta (Ough y Berg, 1971; Febo et al., 1997; Pocock y Waters, 1998; Morris, 1998; Baldini e Intrieri, 2004; Delgado et al., 2005).

\section{I.1.1. Factores de calidad del proceso de vendimia mecanizada.}

El resultado de la vendimia mecanizada depende de factores técnicos y biológicos. Así, los golpes aplicados a las plantas para provocar el desprendimiento de las uvas afectan a la vendimia en términos de rendimiento, calidad de la producción y mantenimiento del viñedo (Intrieri y Poni, 1990; Chaler, 1991; Intrieri y Poni, 1995; Pezzi et al., 2005; Pezzi y Bordini, 2006).

Para evaluar la vendimia mecanizada de un modo global deben considerarse las pérdidas de cosecha que se producen en el proceso, los daños que la máquina produce a las plantas y, por supuesto, las características fisicoquímicas y sensoriales de mostos y vinos. Para optimizar el proceso es muy importante regular correctamente las máquinas en cuanto a velocidad de avance, número y altura de los sacudidores, y amplitud y frecuencia de trabajo de los mismos.

\section{I.1.1.1. Pérdidas del producto.}

Durante el proceso de vendimia mecanizada existe una cantidad variable de uva que no es recogida. Estas pérdidas de producto se pueden clasificar de la siguiente manera (Pezzi et al., 2005; Arfelli et al., 2010):

* Pérdidas visibles

- Pérdidas en suelo: Bayas y racimos de las plantas próximas a las que están siendo sacudidas por la máquina que caen al suelo por la vibración transmitida a través del sistema de empalizamiento.

- Pérdidas en planta: Bayas y racimos que se quedan en las plantas sin recoger al no ser desprendidas con el sacudido de la máquina vendimiadora.

* Pérdidas ocultas

- Mosto que se queda en los elementos de la máquina vendimiadora sin formar parte del producto recogido.

- Mosto disperso en las hojas de las plantas. 
En diferentes estudios se ha podido constatar que las pérdidas ocultas pueden suponer un valor medio del 3\% de la cosecha total (Pezzi et al., 2005; Arfelli et al., 2010).

La frecuencia de sacudido es uno de los principales parámetros de regulación de las máquinas vendimiadoras que afecta a las pérdidas de cosecha. Arfelli et al. (2010) en cv. Montuni, no observaron diferencias en las pérdidas totales al aumentar esta frecuencia, pero si disminuciones significativas en las pérdidas debidas a bayas sin recoger. Pezzi y Caprara (2009), en cv. Lambrusco Grasparossa, observaron que los dos tipos de pérdidas se veían incrementadas con una mayor frecuencia de trabajo. Recientemente, Caprara y Pezzi (2014) han estudiado el efecto de la amplitud de movimiento de los sacudidores sobre las pérdidas de producto; comparando valores de 30 y $90 \mathrm{~mm}$, obtuvieron pérdidas de $7.9 \%$ y $5.1 \%$ respectivamente.

La velocidad de trabajo también es un parámetro importante que afecta al rendimiento de la vendimia mecanizada. Su regulación depende de las condiciones del terreno y de la calidad del labrado principalmente (Pajic et al., 2013), junto con el vigor de las plantas, la disposición de los racimos, el rendimiento de cosecha y la adaptabilidad a la mecanización de la parcela (Intrieri et al., 2008). Autores como Bešlić (2009), Manojlović et al. (2009) y Manojlović et al. (2011), apuntan que los factores con mayor repercusión en las pérdidas de producto son las características del sistema de conducción, el vigor de las plantas y las distancias entre cepas y postes.

La aplicación de agentes de abscisión en los racimos antes de la recolección, para facilitar el desprendimiento de la uva, podría permitir mejorar el rendimiento de las máquinas vendimiadoras al reducir las pérdidas en plantas. Además esta técnica podría ofrecer la posibilidad de adoptar regímenes de trabajo menos enérgicos, disminuyendo el daño ocasionado a las plantas y a la propia uva.

\section{I.1.1.2. Daños provocados a las plantas.}

A una mayor frecuencia de trabajo en la máquina vendimiadora, la energía transferida a la planta se incrementa, causando una mayor defoliación que perjudicaría el agostamiento de las cepas y podría ser, a la vez, causa indirecta de pérdidas ocultas (Pezzi y Caprara, 2009; Intrieri y Poni, 1990). Arfelli et al. (2010) observaron vendimiando mecánicamente a 360, 410 y 460 golpes $\cdot \mathrm{min}^{-1}$ valores crecientes de defoliación desde el 10\% hasta el 25\%.

Por otra parte, durante el trabajo de la máquina vendimiadora cabe la posibilidad de que se produzcan daños en las yemas y rotura de sarmientos, lo que 
podría perjudicar al desarrollo vegetativo y fructífero de las cepas. Actualmente este riesgo ha sido minimizado con un ajuste de la maquinaria en función del viñedo a cosechar.

\section{I.1.1.3. Calidad de la cosecha.}

La vendimia mecanizada puede perjudicar a la calidad de los vinos, debido tanto a la liberación de mosto como a la presencia de hojas o pequeñas partes leñosas en la pasta recogida. La liberación del mosto favorece los procesos de oxidación de fenoles y aromas, su maceración con los hollejos, y el riesgo de inicio prematuro de la fermentación por levaduras apiculadas.

La cantidad de mosto liberado depende del nivel de daño que sufren las uvas al ser golpeadas por los sacudidores, y también de las propiedades físico-mecánicas de la uva, como son la fuerza de desprendimiento del fruto (FDF) y la resistencia a la rotura. Cada cultivar presenta una resistencia a la rotura y una separación del pedicelo característica. En cítricos se ha observado que la susceptibilidad del fruto a los impactos proporcionados por las máquinas cosechadoras depende de la variedad y del estado de maduración (Menesatti et al., 2005; Ortiz et al., 2011).

La extracción de polifenoles se ve favorecida por el contacto del mosto con el hollejo y las semillas de las bayas durante el proceso de vendimia mecanizada, incrementando el contenido de compuestos flavonoides y no flavonoides del mosto (Darías-Martín et al., 2000). Además, con esta maceración, existe el riesgo de que aparezcan sabores herbáceos y terrosos debido a la presencia de hojas o pequeñas partes leñosas en la pasta recogida. Por otra parte la presencia de residuos de productos fitosanitarios, en particular de algunos fungicidas, puede interferir en el proceso de vinificación.

Allen et al. (2011) han observado que el contenido de fenoles totales de mostos (estimado con la absorbancia a $280 \mathrm{~nm}$ ) en cv. Sauvignon blanc, se puede ver modificado por el tipo de vendimia, el tiempo de contacto del mosto con los hollejos y las condiciones ambientales, especialmente la temperatura. Catania et al. (2009), en cv. Catarrato lucido, no detectaron diferencias en este parámetro comparando vendimia manual y mecanizada, mientras que Arfelli et al. (2010) observaron una mayor extracción de polifenoles en la vendimia mecanizada que en la manual.

Por otra parte, el mosto liberado en el proceso de vendimia, es susceptible de ser oxidado y por lo tanto de perder calidad. La oxidación de compuestos fenólicos supone la formación de polímeros con diferente grado de condensación que producen 
colores amarronados en el mosto (pardeamiento), lo que repercute negativamente en las características organolépticas del vino (Macheix et al., 1991). El pardeamiento puede ser enzimático y no enzimático. El primero se produce casi en su totalidad en el mosto, mientras que el segundo predomina en el vino (Oliveira et al., 2011).

El pardeamiento enzimático del mosto está altamente correlacionado con el contenido de hidroxicinamatos (estimado con la absorbancia a $320 \mathrm{~nm}$ ), entre los que se encuentran los ácidos cafeoil tartárico y paracumarotartárico (Cheynier et al., 1986). Tras la rotura de las bayas, la enzima polifenoloxidasa (PPO) es liberada y en presencia de oxígeno, transforma los hidroxicinamatos en quinonas, que siguen reaccionando según su potencial redox y su afinidad electrónica (Li et al., 2008). Allen et al. (2011) describen espectrofotométricamente la oxidación del mosto con un descenso en la absorbancia a $320 \mathrm{~nm}$ y un aumento de la absorbancia a $420 \mathrm{~nm}$, que sirve para evaluar la intensidad del pardeamiento. Esta oxidación del mosto afecta después a las características sensoriales del vino, provocando pérdidas de color, modificación del sabor y aroma, y aumento de la astringencia (Wang, 1990; Ferreira et al., 1997; Escudero et al., 2002; Schneider, 2001; Silva et al., 2002). Por otro lado, la oxidación disminuye el valor nutricional del producto debido a la merma de sus propiedades antioxidantes (Sioumis et al., 2005).

La vendimia mecanizada favorece los fenómenos de oxidación enzimática, ya que existe una mayor actividad de la PPO en los mostos que permanecen en contacto con los hollejos (Vrhovsek, 1998). Allen et al. (2011) obtuvieron mostos procedentes de vendimia manual con una mayor absorbancia a $320 \mathrm{~nm}$ que los procedentes de vendimia mecanizada. Catania et al. (2009), Arfelli et al. (2010) y Allen et al. (2011) coinciden en que los mostos procedentes de vendimia manual presentan valores menores de absorbancia a $420 \mathrm{~nm}$ en diferentes variedades blancas de vid. Comparando distintos regímenes de trabajo de la vendimiadora, Pezzi et al. (2005), observaron mayores absorbancias a $280 \mathrm{~nm}$ y a $420 \mathrm{~nm}$ en mosto con el aumento de frecuencia de sacudido, lo que indica una mayor extracción de polifenoles.

En el caso de vinos blancos, el color se ve fuertemente deteriorado con el contacto de la parte sólida y líquida de la pasta vendimiada. Para evitar las reacciones de pardeamiento el tiempo desde la recogida hasta el procesado e inicio de la fermentación debe ser el menor posible (Ough y Berg, 1971). Para obtener un vino de calidad es también importante el tratamiento con antioxidantes como el metabisulfito potásico, y la inoculación de levaduras seleccionadas. 
Algunos parámetros físico-químicos del mosto pueden verse afectados por el tipo de vendimia o el tiempo de transporte a la bodega, en la medida que incrementan la extracción de componentes del hollejo. Arfelli et al. (2010) observaron que los mostos y vinos procedentes de vendimia mecanizada presentaban valores de $\mathrm{pH}$ mayores que los procedentes de vendimia manual, lo cual se relacionaba con concentraciones significativamente mayores de potasio. Ough et al. (1971) observaron que incrementado el tiempo que transcurre desde la vendimia al procesado, la acidez del mosto disminuye y se incrementa el $\mathrm{pH}$ y el contenido de potasio. Similares resultados se obtienen al comparar los mostos de prensado en bodega a 1 bar con el mosto liberado en la vendimia (Patel et al., 2010; Allen et al., 2011).

Los componentes aromáticos del mosto y del vino se ven influenciados también por los fenómenos de oxidación. Allen et al. (2011) observaron que mostos más oxidados, con una absorbancia a $420 \mathrm{~nm}$ mayor, daban lugar a vinos con una menor concentración de tioles varietales como el 3-mercaptohexanol y el 3-mercaptohexil acetato, de especial relevancia en las notas tropicales en vinos blancos (Lund et al., 2009).

La oxidación que se produce en el vino es de tipo no enzimático. En ella el oxígeno no reacciona directamente con componentes fenólicos pero da como resultado la formación de compuestos inestables que producen pardeamiento (Fernández-Zurbano et al., 1995, 1998; López-Toledano, et al., 2002). Arfelli et al. (2010) analizaron la estabilidad oxidativa del vino, calculando la diferencia de la absorbancia a $420 \mathrm{~nm}$ antes y después de una oxidación forzada en una estufa 48 horas a $50^{\circ} \mathrm{C}$, y observaron mayor estabilidad (menor diferencia de absorbancias) en vinos procedentes de cepas vendimiadas a mano que en vendimia mecanizada. Una vendimia mecanizada a menor frecuencia de sacudido permitiría obtener vinos con una menor absorbancia a $420 \mathrm{~nm}$ que una vendimia más intensa en la que se incrementa el porcentaje de mosteo (Catania et al., 2009).

\section{I.1.2. Técnicas para optimizar la calidad de uva vendimiada mecánicamente.}

Para evitar pérdidas de calidad asociadas a oxidaciones, maceraciones y arranques de fermentación indeseables que pueden darse en la pasta vendimiada mecánicamente, existen diferentes técnicas aplicables, tanto previas como posteriores a la vendimia.

Para limitar los procesos de oxidación, habitualmente, se adiciona a la pasta recogida dióxido de azufre. Este compuesto tiene propiedades antimicrobianas y antioxidantes, si bien dosis excesivas pueden derivar en sabores y aromas 
desagradables (Li et al., 2005). Se puede utilizar compuestos alternativos como el ácido ascórbico (Marks, 1990; Bradshaw et al., 2001), pero el producto no está autorizado en todos los países y su papel antioxidante es variable en función de la concentración y de las condiciones ambientales. También se puede aplicar nieve carbónica, lo cual permite, por otra parte, obtener vinos con una mejor estabilidad oxidativa (Arfelli et al., 2010).

Pari y Pezzi (2009) y Pezzi et al. (2013) han demostrado en diferentes cultivares de vid que la separación de la parte sólida (bayas y racimos desprendidos) de la parte líquida (mosto) en las máquinas vendimiadoras, la refrigeración o la sustitución de aire por gases inertes en los tanques de transporte hasta la bodega, son técnicas útiles para obtener vinos con mejores características cromáticas y una mayor presencia de aromas primarios.

El ajuste de diferentes regulaciones de la maquina vendimiadora es fundamental para mejorar la calidad de la cosecha. La frecuencia de los sacudidores es un parámetro clave, que debe compatibilizar una alta eficiencia de vendimia con una baja liberación de mosto (Catania et al., 2009). En los viñedos con empalizamiento, esta frecuencia se debe elegir en función de la velocidad de avance de la máquina, la posición de los racimos, la cantidad de vegetación existente y las características mecánicas de la variedad de uva (Clary et al., 1990). Junto a la frecuencia de vibración es importante regular otros parámetros como la velocidad de avance (Pezzi et al., 2005) y la amplitud de movimiento de los agitadores (Caprara y Pezzi, 2014).

Diferentes estudios han demostrado que la aplicación de fitorreguladores en el viñedo, en los días previos a la vendimia, es capaz de facilitar el desprendimiento del fruto (Fidelibus et al., 2007a; González-Herranz et al., 2009; Fidelibus y Cathline, 2010). La utilización de estos productos, llamados agentes de abscisión, podría hacer posible una vendimia mecanizada menos enérgica que disminuiría el daño provocado a las plantas y la cantidad de mosto libre liberado, lo que redundaría en una mayor calidad de los mostos y vinos obtenidos. En los siguientes apartados se abordan los mecanismos fisiológicos implicados en la abscisión de los frutos, su regulación hormonal, y los reguladores de crecimiento susceptibles de ser utilizados como agentes de abscisión en la vid. 


\section{I.2. La abscisión de los frutos.}

Se denomina abscisión a la separación de hojas, frutos, flores y otros órganos del resto de la planta. Se produce en una región llamada zona de abscisión que está formada por una capa de células específicas que llegan a ser morfológica y fisiológicamente diferenciadas durante el proceso (Taiz y Zeiger, 2006). La abscisión es frecuentemente el punto final de la senescencia de los órganos vegetales, e implica cambios metabólicos, en la estructura celular y en la expresión génica (Taylor y Whitelaw, 2001).

Este apartado se centra en los procesos fisiológicos que se dan en la abscisión de los frutos, haciendo especial hincapié en su regulación hormonal.

\section{I.2.1 El proceso fisiológico de la abscisión.}

La abscisión se produce como respuesta a estímulos hormonales. La formación de la zona de abscisión es el resultado de un conjunto de señales ejercidas por el etileno y las auxinas en el crecimiento de las células. El nivel de auxinas de la zona de abscisión controla la sensibilidad al etileno y, por ello, cualquier factor que afecte al suministro de auxinas en esa zona también afecta al proceso (Taylor y Whitelaw 2001).

La sensibilidad al etileno de los frutos se incrementan según avanza la maduración (Reid, 1985). Cuando las células son sensibles al etileno, se produce la síntesis y secreción de celulasas y otras enzimas hidrolíticas que degradan las paredes celulares en la zona donde se producirá la separación del fruto. Además, la secreción de estas enzimas incrementa la actividad de las peroxidasas, y produce la pérdida de calcio y pectinas de las paredes celulares, lo que permite la desintegración del tejido de la zona de abscisión (Wittenbach y Bukovac, 1975; Addicott, 1982; Osborne, 1989).

La capa de abscisión está constituida por células morfológicamente diferentes al resto (Roberts et al., 2000). Son células normalmente pequeñas, de forma cúbica y con citoplasma denso, dispuestas transversalmente al eje del órgano (Addicott, 1982; Sexton y Roberts, 1982; Osborne, 1989). La degradación química de la lámina media entre las células y la desintegración parcial de las paredes celulares va acompañada de una proliferación celular desigual en la zona de abscisión. El aumento del tamaño de las células de una capa frente al aumento casi nulo de las células de la capa contigua produce una tensión mecánica que facilita la rotura de las uniones entre 
abscisión (Figura I.2) cerraría posibles vías de entrada de microorganismos (Ballinger y Nesbitt, 1982; Kou et al., 2007).

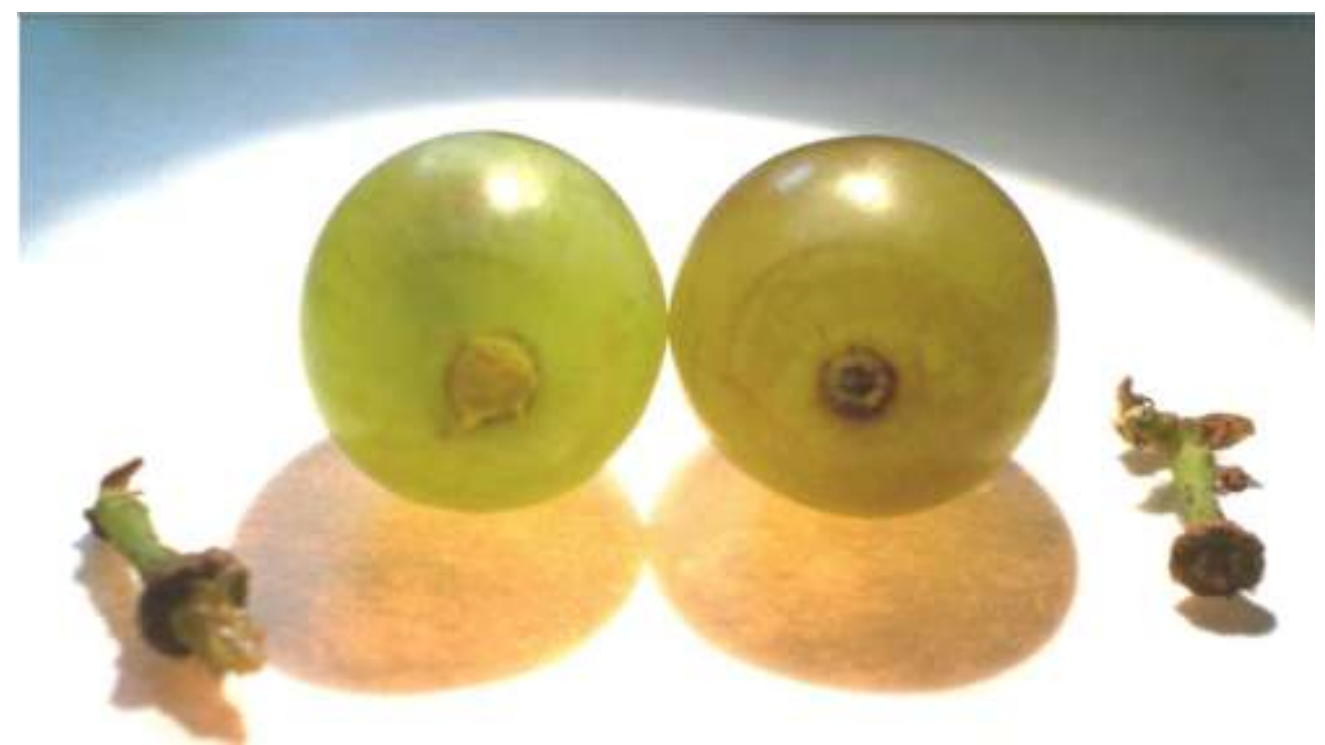

Figura I.2. Uva sin cicatriz (izquierda) y uva con cicatriz (derecha) en la zona de abscisión.

El potencial de abscisión de la uva pude ser valorado cuantitativamente con la medida de la FDF (Wittenbach y Bukovac, 1974), utilizando un dinamómetro que registra la fuerza que permite separarla del pedicelo.

\section{I.2.2 Regulación hormonal de la abscisión.}

Los procesos fisiológicos están gobernados por equilibrios hormonales complejos, en los que las hormonas de las plantas interactúan entre ellas (Mullins et al., 1992; Kondo y Takano, 2000). La maduración de la uva está regulada por equilibrios hormonales favorables al ácido abscísico, etileno y brasinoesteroides (Coombe y Hale, 1973; Downton y Loveys, 1978; Giovannoni, 2004; Mailhac y Chervin, 2006).

El etileno $\left(\mathrm{C}_{2} \mathrm{H}_{4}\right)$ es una hormona vegetal gaseosa, producido en la mayoría de los tejidos vegetal y tipos de células (Abeles et al., 1992; Schaller y Kieber 2002; Wang et al., 2002; Tsuchisaka y Theologis, 2004). El etileno afecta a muchos procesos de las 
plantas como la germinación de semillas, la formación de raíces, el desarrollo floral, la maduración de frutos, la senescencia y la abscisión de órganos, y las respuestas al estrés (Abeles et al., 1992).

En las plantas, el etileno es sintetizado a partir de metionina. En un primer paso, la S-adenosil-metionina se convierte en ácido 1-aminociclopropano-1-carboxílico (ACC) interviniendo la enzima ACC sintetasa (ACS) y, en un segundo paso, el ACC se oxida a etileno mediante la enzima ACC oxidasa (ACO) (Yang y Hoffman, 1984). Las dos enzimas mencionadas son codificadas por más de un gen, regulados de manera diferente (Lin et al., 2009).

El etileno desencadena el proceso de abscisión (Brown, 1997) tanto en frutos climatéricos como no climatéricos, aunque existen otros factores reguladores. Se ha observado que existe una relación directa entre la concentración de etileno en los tejidos y la abscisión de frutos en la vid, siendo esa concentración dependediente del estado de madurez en que se encuentre el fruto (Hilt y Bessis, 2003).

Las auxinas actúan en fruta madura reduciendo la sensibilidad al etileno en la zona de abscisión, de modo que aplicaciones exógenas de la hormona pueden retrasar la abscisión del fruto (Denney y Martin, 1994; Henderson y Osborne, 1994; Stern et al., 1995). Los frutos con semillas, las cuales son fuente de auxinas, son menos propensas a la abscisión que los frutos apirenos (Edgerton y Greenhalgh, 1969).

Por otra parte, el mantenimiento de concentraciones de auxinas superiores a la óptima estimula la producción de etileno en los órganos (Taiz y Zieger, 2006), lo que ha dado lugar al uso comercial de productos auxínicos como agentes defoliantes.

El ácido abscísico interviene en el proceso de abscisión, probablemente de forma indirecta, estimulando la síntesis de etileno y/o actuando sobre el transporte y metabolismo de las auxinas (Osborne, 1989). Giberelinas, citoquininas y auxinas pueden ser bloqueadas por el etileno y el ácido abscísico.

Los jasmonatos intervienen en el proceso de abscisión al provocar cambios en el metabolismo de los azúcares en la zona de abscisión, donde se incrementa la actividad celulasa que degrada los polisacáridos de las paredes celulares (Ueda et al., 1996; Koda, 1997). Los estudios realizados por Hartmond et al., (2000) y Kender et al., (2001) en naranjo (Citrus sinensis L.) han demostrado que la aplicación de metil jasmonato (MeJA) con objeto de promover la abscisión de los frutos produce, en primer término, una estimulación de la producción de etileno en los mismos. En general, se ha observado que el estado del desarrollo de la fruta en el momento de la 
aplicación de los jasmonatos es un factor importante para el aumento de la producción de etileno en manzana Malus domestica Borkh. (Fan et al., 1997), pera Pyrus communis L. (Kondo et al., 2007) y fresa Fragaria ananassa Duch. (Mukkun y Singh, 2009).

Malladi et al. (2012) han observado que aplicaciones combinadas de MeJA con aminoetoxivinilglicina ( $A V G$, un inhibidor de la síntesis de etileno) tienen menor efecto en la abscisión de frutos de arándano (Vaccinium spp.) que las aplicaciones con MeJA solamente, lo que indica que este último fitorregulador actuaría, al menos en parte, aumentando la producción de etileno. Por otro lado, Kim et al. (2013), sugieren que la abscisión de órganos florales en Arabidopsis thaliana sería promovida por etileno y ácido jasmónico de manera independiente.

\section{I.3. Utilización de fitorreguladores para favorecer el proceso de abscisión de los frutos.}

Como se ha comentado anteriormente, la vendimia mecanizada produce daños mecánicos a la uva de vinificación y produce liberación de mosto, que puede deteriorar la calidad de la cosecha al fomentar procesos de oxidación indeseables. Una opción para minimizar este problema podría ser la aplicación de agentes de abscisión antes de la recolección, con objeto de facilitar el desprendimiento de las bayas y posibilitar así el uso de regímenes de trabajo menos intensos en las vendimiadoras.

Los agentes de abscisión también encuentran una aplicación interesante en uva de pasificación (Fidelibus et al., 2007a). Las máquinas vendimiadoras están diseñadas para uvas de vinificación y utilizadas en estos viñedos pueden causar daños a las bayas, haciéndolas inviables para elaborar pasas.

En las últimas décadas se han evaluado diferentes reguladores del crecimiento como agentes de abscisión de la uva. El etefón es un liberador de etileno que se empezó a estudiar durante la década de los setenta del siglo pasado. Más recientemente se han estudiado productos como el metil jasmonato (MeJA) y el ácido 1-aminociclopropano-1-carboxílico (ACC).

El 5-cloro-3-metil-4-nitro-1H-pirazol (CMNP) es un agente específico para el desprendimiento de cítricos maduros (Pozo y Burns, 2009). El ácido $\mathrm{C}_{12} \mathrm{H}_{17} \mathrm{NaO}_{7}$, comercializado como Dikegulac, modifica el balance auxinas-etileno, acelerando la abscisión en cítricos (Pozo et al., 2004). La coronatina, toxina químicamente similar al 
MeJA producida bacterias Pseudomonas syringae, presenta efectos significativos en la abscisión de cítricos (Burns et al., 2003) y vid (Fidelibus et al., 2007a).

Algunos productos que actúan como agentes de abscisión, se comercializan combinados con liberadores de etileno. Tal es el caso de la ciclanilida, sustancia inhibidora del transporte de auxinas que, combinada con etefón (Finish), es utilizada como defoliante en el cultivo del algodón (Stewart et al., 2000). El fosfato monopotásico $\left(\mathrm{KH}_{2} \mathrm{PO}_{4}\right)$ combinado o no con liberadores de etileno, se ha estudiado como promotor de la abscisión de frutos en olivo (Barranco et al., 2002; Barranco et al., 2004).

\section{I.3.1. Liberadores y generadores de etileno.}

El etefón, CEPA o ethrel (ácido 2-cloroetil fosfónico), es un producto que actúa liberando etileno, cloruro y fosfato a pH entorno a 4,5 (Maynard y Swan, 1963). Como regulador del crecimiento aplicado sobre la planta es capaz de liberar etileno en el interior de los tejidos vegetales (Yang y Hoffman, 1984). El producto penetra en los tejidos principalmente por zonas de la cutícula que tienen un espesor inferior al habitual (Nir y Lavee, 1981).

En la revisión publicada por Szyjewicz et al. (1984), se recogen estudios que han probado su utilidad como regulador del desarrollo vegetativo y cualitativo de viñedo, destacando como mejorador de color de la uva. Los efectos del etefón son muy variables en función del momento y las dosis de tratamiento, la variedad, el vigor de la planta y las condiciones ambientales y de cultivo (Szyjewicz y Kliewer, 1982; Szyjewicz et al., 1984; Lavee, 1987).

El etefón ha sido probado como promotor de la abscisión en cultivos como arándano (Vaccinium spp.) (Malladi et al., 2012), olivo (Olea europaea L.) (Yousefi et al., 2012), cereza (Prunus avium L.) (Elfving et al., 2009) o naranja (Citrus sinensis L.) (Pozo y Burns, 2009) y por su puesto en la vid. En Vitis labrusca cv. Concord, Morris y Cawthon (1981, 1982a, 1982b), estudiaron los efectos del etefón sobre la abscisión del fruto en función de la dosis y el momento de aplicación, y observaron que concentraciones entre 400 y $800 \mathrm{mg} \cdot \mathrm{L}^{-1}$ aplicadas entre 8 y 20 días antes de la vendimia, reducían significativamente la FDF y promovían la cicatrización de la zona de abscisión. En tres cultivares distintos de Vitis rotundifolia, Mortensen (1980) encontró incrementos significativos del número de bayas cicatrizadas tras aplicar entre 600 y $1200 \mathrm{mg} \cdot \mathrm{L}^{-1}$ de etefón, pero también altos porcentajes de bayas caídas prematuramente antes de la recolección. En cultivares diferentes de Vitis vinífera, El- 
Zeftawi (1982) observó una disminución en la fuerza de separación de las uvas del racimo, frente a controles sin tratar, con dosis de etefón ligeramente superiores a las citadas anteriormente. Por su parte, Eynard (1970) y Hedberg y Goodwin (1980) obtuvieron resultados variables según el cultivar pulverizando soluciones a concentraciones entre 500 y $2000 \mathrm{mg} \cdot \mathrm{L}^{-1} 10$ días antes de la vendimia.

Son pocos los trabajos que han estudiado si las aplicaciones de etefón en los días previos a la vendimia, para facilitar la abscisión de las bayas, tenían o no algún efecto en la concentración de sólidos solubles, $\mathrm{pH}$ o acidez del mosto. Mientras que Morris y Cawthon (1981) no observaron diferencias entre plantas tratadas y controles en cv. Concord, otros autores como Eynard (1975) observaron en cinco cultivares distintos que concentraciones de etefón entre 500 y $2000 \mathrm{mg} \cdot \mathrm{L}^{-1}$, aplicadas 10 días antes de la cosecha, incrementaban la concentración de sólidos solubles y disminuían la acidez total del mosto.

La caída prematura de frutos puede ser un efecto muy negativo de los tratamientos de etefón como agente de abscisión (Mainland y Nesbitt, 1974; Mainland et al., 1977; Hedberg y Goodwin 1980; Fidelibus et al., 2007a; Rizzuti et al., 2015), ya que puede dar lugar a una pérdida significativa de cosecha. Por otra parte, diversos autores han puesto de manifiesto que los tratamientos de etefón en los días previos a la vendimia pueden tener un efecto de deshojado de las plantas (Eynard, 1970; Hedberg y Goodwin, 1980; El-Zeftawi, 1982), lo cual perjudica el agostamiento y podría tener un efecto depresivo en las cepas. Finalmente, el etefón puede provocar retrasos de la brotación al producir daños en los meristemos apicales de las yemas francas (Hale et al., 1970; Hirschfeld y Lavee, 1980).

El ácido 1-aminociclopropano-1-carboxílico (ACC) es el precursor bioquímico del etileno, por lo tanto, aplicado sobre las uvas puede estimular la síntesis natural de la hormona (generador de etileno). La disponibilidad de ACC para la producción de etileno podría estar regulada por la existencia de tres formas conjugadas del ACC, que son: el malonyl-ACC descubierto por Amrhein et al. (1981), el V-glutamyl-ACC descubierto por (Martin et al., 1995), y el jasmonyl-ACC (Staswick y Tiryaki, 2004). Este último conjugando podría actuar como modulador de la síntesis de etileno y ácido jasmónico, aunque los mecanismos bioquímicos implicados se desconocen (Van de Poel y Van der Straeten, 2014). Además de su acción como precursor del etileno, investigaciones recientes sugieren un papel alternativo del ACC como molécula de señalización, capaz de actuar como regulador del crecimiento de las plantas independientemente del etileno (Yoon y Kieber, 2013). 
El ACC ha sido registrado comercialmente en Estados Unidos en 2013 como regulador del crecimiento para el aclareo de frutos. En estudios realizados en vid (Justia, 2014) pulverizaciones de ACC en floración han reducido el peso y el número de bayas de los racimos frente a los testigos, sin modificar la longitud del raquis. La aplicación de ACC como agente de abscisión del fruto ha dado buenos resultados en vid (Fidelibus et al., 2007a). Sin embargo en aceituna de mesa (Olea europaea L.), se ha observado una caída prematura de frutos y una defoliación significativa en los arboles tratados (Burns et al., 2008).

\section{I.3.2 Metil jasmonato.}

Los jasmonatos son compuestos pentacíclicos derivados de los lípidos, que se encuentran ubicuos (Meyer et al., 1984; Hamberg y Gardner, 1992) y son exclusivos del reino de las plantas (Creelman y Mullet, 1997). Los jasmonatos son sintetizados en la ruta de los octadecanoides, a partir del ácido linolénico (Vick y Zimmerman, 1984). Entre los tipos de metabolitos originados a partir del ácido jasmónico y MeJA se encuentran formas libres y conjugadas de poliaminas, quinonas, terpenoides, alcaloides, fenilporpanoides, glucosinalatos y antioxidantes (Memelink et al., 2001).

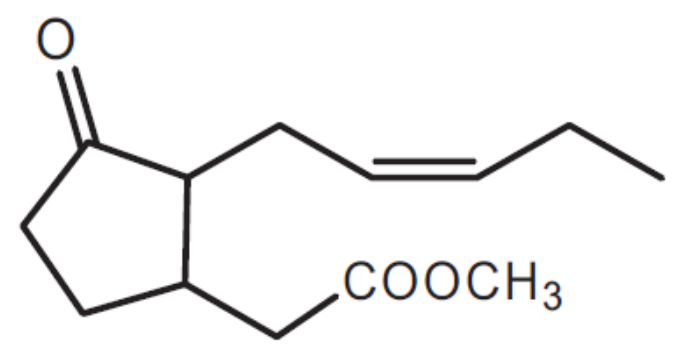

Figura I.3. Molécula de metil jasmonato (Ghasemi Pirbalouti et al., 2014).

El MeJA (Figura I.3) fue aislado por primera vez del aceite esencial de Jasminum grandiflorum (Demole et al., 1962). Los jasmonatos son un grupo de hormonas vegetales (Sembdner y Parthier, 1993; Creelman y Mullet, 1995) que inhiben la división (Ueda y Kato, 1982) y la elongación celular (Ueda et al., 1995). Todas las respuestas a los jasmonatos, tanto aplicados externamente como liberado internamente como consecuencia de situaciones de estrés, parecen estar correlacionados con alteraciones en la expresión genética a tres niveles: (1) inducción de la síntesis de polipéptidos específicos, (2) inhibición selectiva de la síntesis de 
polipéptidos existentes antes del tratamiento, y (3) retraso en la regulación de biosíntesis de proteínas a nivel general (Reinbothe et al., 1994).

Los jasmonatos se encuentran a concentraciones de entre 10 y $100 \mathrm{ng} \cdot \mathrm{g}^{-1} \mathrm{de}$ peso fresco en plantas sanas, pero éstas pueden ser mayores en plantas o partes de plantas afectadas por estrés biótico (ataques de insectos o patógenos) y abiótico (sequía, estrés osmótico, luz UV, bajas temperaturas, ozono o calor), o que han sufrido daños mecánicos (Ghasemi Pirbalouti et al., 2014). Diferentes trabajos (Memelink et al., 2001; Wasternack, 2007; Wasternack y Hause 2013), han demostrado que los jasmonatos activan señales de transducción para la síntesis de proteínas y metabolitos secundarios de defensa, como respuesta a diferentes tipos de estrés. Además, se ha visto que los jasmonatos estimulan procesos de resistencia sistémica inducida (Van Loon, 2000).

Es bien conocido que los jasmonatos interactúan con otras hormonas vegetales en muchos procesos fisiológicos. Es probable que las auxinas reduzcan algunos procesos inducidos por los jasmonatos y viceversa. Así, por ejemplo, la inhibición del crecimiento de raíces provocada por los jasmonatos parece ocurrir preferentemente a través de la modulación de los efectos de las auxinas en el crecimiento y desarrollo de aquellas (Wasternak y Hause, 2013).

La concentración endógena de jasmonatos en las uvas con semillas es mayor al inicio de su desarrollo siguiendo luego un descenso constante hasta la madurez, tal y como han constatado Kondo y Fukuda (2001). Diferentes parámetros de calidad de los frutos pueden verse mejorados con aplicaciones de MeJA durante su desarrollo. Así, en frambuesa (Rubus spp.), la concentración de sólidos solubles se ha visto incrementada y la acidez total reducida en frutos tratados frente a testigos (Wang y Zheng, 2005). Tratamientos con jasmonatos durante la maduración incrementan la degradación de la clorofila y la biosíntesis de antocianinas, ácido ascórbico y $\beta$ carotenos en los frutos. Se han detectado, además, incrementos en los niveles de antioxidantes en manzana, plátano (Musa X paradisiaca) y mango (Mangifera indica) (Rudell et al., 2002; Schreiner y Huyskens-Keil, 2006). Kondo et al. (2000) observaron que los efectos en el color de cerezas y manzanas dependían principalmente del carácter climatérico o no climatérico del fruto. En mango (Lalel et al., 2003), manzana (Fan y Mattheis, 1999; Kondo et al., 2005; Li et al., 2006) y fresa (Ayala-Zabala et al., 2005; De la Peña-Moreno et al., 2010) se ha incrementado la producción de aromas volátiles con aplicaciones de jasmonatos. En fresa se ha observado un incremento de la concentración de terpenos (Ayala-Zabala et al., 2005), alcoholes y esteres en los frutos (Peña-Cortés et al., 2005). 
Ruiz-García et al. $(2012,2013)$ han demostrado que las aplicaciones de MeJA al inicio de la maduración pueden ser útiles para mejorar los parámetros de madurez tecnológica, el contenido fenólico, color y aroma en mosto y vino cv. Monastrell. En los estudios realizados, los vinos procedentes de bayas tratadas fueron claramente preferidos frente a los controles en el análisis sensorial (Ruiz-García et al., 2012).

Aplicaciones de MeJA tras la recolección mantienen en el tiempo la calidad de muchas hortalizas y flores (Rohwer y Erwin, 2008; Ghasemi Pirbalouti et al., 2014), ya que favorecen las defensas naturales frente a ataques de insectos y patógenos microbianos (Baldwin, 1998; Gozzo, 2003; Bower et al., 2005), y reducen el daño por frío durante el almacenamiento en cámaras frigoríficas (Meir et al., 1996; Fung et al., 2004). Con estas aplicaciones, Mukkun y Singh (2009) contuvieron el deterioro de frutos causado por Botrytis cinerea en fresa. Repka et al. (2004) han descrito respuestas múltiples al tratamiento de hojas y cultivos celulares de vid con MeJA, incluyendo reacciones de hipersensibilidad, formación de callo o expresión de genes para proteínas de defensa.

El MeJA ha sido estudiado como potencial agente de abscisión en diferentes cultivos como tomate cherry (Lycopersicon esculentum) (Beno-Moualem et al., 2004), olivo (Burns et al., 2008), naranja (Hartmond et al., 2000; Kender et al., 2001), arándano (Malladi et al., 2012), uva de mesa y de pasificación (Fidelibus et al., 2007a; González-Herranz et al., 2009; Fidelibus y Cathline, 2010) y uva de vinificación (Fidelibus et al., 2007a). Los trabajos realizados han ensayado la aplicación de MeJA, solo o combinado con otros fitorreguladores, a diferentes dosis y/o momentos de tratamiento, con el fin de evaluar los efectos en parámetros como la FDF, la caída de frutos o la aparición de tejido cicatricial en la zona de abscisión.

Hartmond et al. (2000) realizaron los primeros ensayos de aplicación de MeJA como agente de abscisión en cítricos, evaluando el efecto de distintas concentraciones de producto, que llegaban hasta $222,5 \mathrm{~g} \cdot \mathrm{L}^{-1}$, con distintos tipos de tratamiento (por inmersión del fruto, mediante pulverización a toda la planta, o localizada en la zona de abscisión del fruto). Los autores observaron que los tratamientos con dosis medias diez días antes de la recolección eran los más eficaces, ya que disminuían la FDF sin causar una excesiva caída de frutos. También en naranjo, Kender et al. (2001) demostraron que los tratamientos combinados de MeJA y CMNP (5-cloro-3-metil-4nitro-1 $\mathrm{H}$-pirazol) mejoraban la eficiencia del MeJA, aunque dosis altas del tratamiento tenían un efecto defoliante no deseado sobre las plantas. 
En arándano, (Malladi et al., 2012) observaron que tratamientos de MeJA a concentraciones de $4485 \mathrm{mg} \cdot \mathrm{L}^{-1}$ inducían una abscisión de frutos rápida y generalizada, tan solo un día después de su aplicación. Sin embargo con dosis tan altas, aparecían síntomas de fitotoxicidad en las hojas.

Como en otros cultivos, los resultados que se han obtenido con la aplicación de MeJA en viñedo han sido variables en función del cultivar considerado, tal y como han puesto de manifiesto Fidelibus et al. (2007a), González-Herranz et al. (2009), Fidelibus y Cathline (2010) y Rizzuti et al. (2015) en variedades diferentes de uva de mesa, de pasificación y de vinificación. Fidelibus et al. (2007a) han mostrado en cv. Thompson seedless que tratamientos de MeJA entre 45 y $4485 \mathrm{mg} \cdot \mathrm{L}^{-1}$ proporcionaron reducciones importantes de la FDF, aunque las dosis máximas provocaban una intensa caída prematura de bayas. Para evitar el problema en esas condiciones de cultivo, González-Herranz et al. (2009) establecieron que el momento óptimo de tratamiento sería tres días antes de la recolección. Fidelibus et al. (2007a) en variedades de vinificación (cv. Merlot y cv. Cabernet sauvignon) observaron que tratamientos a $4485 \mathrm{mg} \cdot \mathrm{L}^{-1}$ producían una menor caída de fruto que en el caso de las variedades apirenas de mesa, por debajo de un $10 \%$.

Por otra parte, se ha visto que tratamientos de MeJA con dosis entre 1780 $\mathrm{mg} \cdot \mathrm{L}^{-1}$ y $4485 \mathrm{mg} \cdot \mathrm{L}^{-1}$ favorecen la cicatrización de la zona de abscisión de las uvas (González-Herranz et al., 2009; Fidelibus y Cathline, 2010). Esta cicatrización podría tener un efecto muy positivo en la calidad de la uva vendimiada mecánicamente ya que eliminaría puntos de entrada de microorganismos. Además, la mayor presencia de bayas con cicatriz podría reducir la liberación de mosto, susceptible de ser oxidado.

No existen investigaciones en uva de vinificación que hayan evaluado el efecto de la aplicación de agentes de abscisión como el MeJA sobre el rendimiento de la vendimia mecanizada, y sus posibles beneficios sobre la calidad de mostos y vinos. También sería interesante estudiar la aplicación combinada del MeJA con otros fitorreguladores, para aprovechas posibles sinergias entre ellos que permitieran reducir las dosis de productos, disminuyendo así los costes de los tratamientos y los niveles de residuos en los frutos. 


\section{II.OBJETIVOS Y PLANTEAMIENTO EXPERIMENTAL}




\section{OBJETIVOS Y PLANTEAMIENTO EXPERIMENTAL.}

El objetivo general de la presente Tesis Doctoral es evaluar el potencial de la aplicación prevendimia de agentes de abscisión de la uva como técnica útil para facilitar la recolección mecanizada y obtener uvas y vinos de mayor calidad. Para lograr este objetivo general se han planteado los siguientes objetivos específicos:

1. Estudiar la influencia de la aplicación prevendimia de distintas concentraciones de metil jasmonato (MeJA) sobre el proceso de abscisión de la uva, evaluando la fuerza de desprendimiento del fruto, la presencia de tejido cicatricial en la zona de abscisión y la incidencia de posibles efectos adversos como defoliación de las plantas o caída prematura de frutos.

2. Evaluar los efectos aditivos y de interacción de los tratamientos prevendimia de MeJA, combinados con etefón y con ácido 1-aminociclopropano-1-carboxílico (ACC) sobre el proceso de abscisión, incluyendo la acción sobre los niveles de etileno en los tejidos del fruto en el caso de la combinación con ACC.

3. Evaluar la influencia de tratamientos combinados de MeJA y etefón previos a la recolección sobre el rendimiento y la liberación de mosto en la vendimia mecanizada bajo distintos regímenes de trabajo, y sobre las características fisicoquímicas del mosto y del vino.

El trabajo experimental se ha llevado a cabo entre 2009 y 2013. Para alcanzar los objetivos propuestos se han realizado tres ensayos de campo, dos de ellos en viñedo cv. Verdejo en la D.O. Rueda (Ensayo 1 y 3), y un tercero en Parlier (California) con cv. Thompson seedless, fruto de una estancia predoctoral en la Universidad de Davis realizada en 2013 (Ensayo 2).

En un primer momento, se estudiaron los efectos en la abscisión del fruto de aplicaciones sobre los racimos 10 días antes de vendimia distintas concentraciones de MeJA combinadas en diseños de tipo factorial con etefón (Ensayo 1) y ACC (Ensayo 2). Ambos ensayos se enmarcan en los objetivos 1 y 2 de la Tesis, En el Ensayo 1 se analizó la influencia de los tratamientos experimentales sobre las características físicoquímicas del mosto, mientras que el Ensayo 2 incluyó específicamente el estudio de la evolución del nivel endógeno de etileno en los tejidos del fruto desde el momento del tratamiento hasta la recolección.

Una vez demostrado en los dos primeros experimentos el interés potencial de los agentes de abscisión para facilitar el desprendimiento del fruto en la vendimia 
mecanizada, se puso en marcha el Ensayo 3. En este trabajo se estudiaron tratamientos combinados de MeJA y etefón con las dosis más favorables obtenidas en el Ensayo 1, evaluando su efecto en el rendimiento de la vendimia utilizando una máquina vendimiadora con diferentes regímenes de trabajo. Se analizó el impacto de los tratamientos sobre la composición de mostos y vinos (objetivo 3). 
III.ENSAYO 1 


\section{ENSAYO 1.}

\section{Potential of combined ethephon and methyl jasmonate treatments for improving mechanical harvesting of wine grapes.}

(Potencialidad de los tratamientos combinados de etefón y metil jasmonato para mejorar la vendimia mecanizada de uva de vinificación).

Autores: L. Uzquiza, R. González, M. R. González y P. Martín.

Departamento de Producción Vegetal y Recursos Forestales, Universidad de Valladolid, Av. Madrid 57, C.P/ 34004, Palencia, España.

Publicado en: European Journal of Horticultural Science, 78 (4): 169-175. Año: 2013.

\section{III.1. Resumen}

Los agentes de abscisión reducen el daño producido a las uvas y el volumen de mosto liberado durante la vendimia mecanizada, evitando oxidaciones indeseables y procesos de fermentación previos a la vinificación. Se ha demostrado que reguladores de crecimiento como el etefón o el metil jasmonato son efectivos, por separado, para reducir la fuerza de desprendimiento del fruto (FDF) en diferentes cultivares de viñedo, sin embargo, los efectos aditivos o interacciones de ambos productos en tratamientos combinados no han sido investigados hasta ahora. El objetivo de este estudio fue evaluar el potencial uso de etefón y metil jasmonato, separadamente y en combinación, como agentes de abscisión para mejorar la calidad de la vendimia mecanizada en uva de vinificación cv. Verdejo. Los experimentos se realizaron en 2009, 2010 y 2011, utilizando un diseño factorial en el que racimos maduros cv. Verdejo se pulverizaron con diferentes soluciones de metil jasmonato $(0$, 10, 20 ó $40 \mathrm{mmol} \cdot \mathrm{L}^{-1}$ ) y etefón (0 ó $1000 \mathrm{mg} \cdot \mathrm{L}^{-1}$ ). La FDF y el estado de la capa de abscisión del fruto fueron controladas hasta 8 días después de las aplicaciones. El etefón redujo la FDF a partir de 4 días después de aplicar los tratamientos en las 3 campañas, manteniendo valores inferiores a los controles hasta el momento de la vendimia. El metil jasmonato tuvo menor efecto que el etefón y disminuyó la FDF desde los 6-8 días después de las pulverizaciones. Se detectó un efecto aditivo en el 
análisis de la varianza, la cual hizo que la combinación de etefón con metil jasmonato fuera más efectiva que la aplicación de cualquiera de los agentes por separado. Los menores de valores de FDF antes de la vendimia correspondieron a las plantas cotratadas, con una reducción de hasta el $45 \%$ respecto a los controles sin tratar. Además, los tratamientos combinados incrementaron significativamente el porcentaje de bayas que presentaban una cicatriz de abscisión seca a partir de los 8 días después de la aplicación, alcanzando valores acumulados de hasta el 60\% en 2011. Los dos agentes de abscisión estudiados apenas afectaron a la composición de los mostos, y no produjeron efectos adversos como caída prematura de frutos antes de la vendimia o defoliación. Estos resultados demuestran que los tratamientos combinados de etefón y metil jasmonato son potencialmente útiles para mejorar la calidad de la vendimia mecanizada de uva cv. Verdejo. Son necesarias investigaciones para determinar las concentraciones exactas de agentes de abscisión requeridas para facilitar el desprendimiento de los frutos, y para establecer los ajustes óptimos de las máquinas vendimiadoras en viñedos tratados en diferentes condiciones de cultivo.

Palabras clave: Abscisión - desprendimiento de frutos - etileno - mosto - reguladores de crecimiento- Vitis vinifera $L$.

\section{III.2. Summary}

Abscission agents could reduce the damage to grapes and the volume of juice released during mechanical harvesting, avoiding undesirable oxidation and fermentation processes before the winemaking begins. Plant growth regulators such as ethephon or methyl jasmonate have been shown to be effective separately to reduce fruit detachment force (FDF) in different grapevine cultivars, however, additive and interaction effects of both products in combined treatments have not been evaluated yet. The objective of this study was to evaluate the potential use of ethephon and methyl jasmonate, separately or in combination, as abscission agents to improve the quality of machine-harvested 'Verdejo' wine grapes. The experiments were conducted in 2009, 2010 and 2011, using a fully crossed factorial design where mature clusters of 'Verdejo' grapevines were sprayed with different solutions containing methyl jasmonate $\left(0,10,20\right.$ or $\left.40 \mathrm{mmol} \cdot \mathrm{L}^{-1}\right)$ and ethephon (0 or $\left.1000 \mathrm{mg} \cdot \mathrm{L}^{-1}\right)$. FDF and stem end condition of the berries were monitored for a maximum of 8 days after the applications. Ethephon reduced FDF 4 days after treatment in all growing seasons, maintaining values below those of controls until harvest. Methyl jasmonate had less effect than ethephon and declined FDF from 6-8 days after the sprayings. An additive effect was 
detected in the analysis of variance, which makes the combination of ethephon and methyl jasmonate more effective than either agent alone. The lowest FDF values just before harvest corresponded to cotreated plants, with reductions up to $45 \%$ relative to untreated controls. Moreover, combined treatments significantly increased the percentage of detached berries presenting dry stem scars up to 8 days after the application, reaching accumulated values up to $60 \%$ in 2011. Both abscission agents little affected must composition parameters, and did not produce adverse effects as preharvest fruit drop or defoliation. These results demonstrate that combined treatments with ethephon and methyl jasmonate are potentially useful to improve quality of mechanically harvested 'Verdejo' grapes. Additional research is needed to provide the exact concentrations of abscission agents required for consistent fruit loosening in practical applications, and to establish the optimal harvester settings in treated vineyards at different growing sites.

Key words. Abscission - ethylene - fruit-loosening - must - plant growth regulators Vitis vinifera $\mathrm{L}$.

\section{III.3. Introduction}

Mechanical harvesting is an important technique in order to contain the operating costs of the vineyard, but may have adverse effects on wine characteristics. The must production during the process, mostly due to the energetic action of the shakers, which knock against the clusters to allow the detachment of the berries, is the major factor impacting on wine quality (BALDINI and INTRIERI, 2004). The breaking of the grapes and the release of free must cause the trigger of some biochemical processes (oxidation and uncontrolled fermentation) before being delivered to the winery, that negatively affect the stability and organoleptic caracteristics of the wine (MEYER, 1969; NAGEL and GRABER, 1988). Although harvesting equipment has been improved over the years to minimize berry damage, varieties with delicate skin are still problematic (WALG, 2007).

The grape juice production depends on many factors, including physicalmechanical characteristics of the berry as its breaking strength and its detachment from the pedicel (CARRARA et al., 2007), ambient factors (CATANIA et al., 2009), and speed and frequency of the shakers of the harvesting machine. A decrease in the fruit detachment force (FDF) could allow working at a lower varying shaker frequency and, therefore, must production and damages in berries and vines might be reduced (CARRARA et al., 2007). In this sense, the preharvest application of fruit loosening 
agents (chemical products that stimulate the abscission) on wine grapes could be potentially useful to improve harvest yield and quality.

Abscission of leaves and fruits respond to developmental cues and biotic and abiotic stresses. The abscission zone is developed from the basal part of organ and further differentiated as separation and protection layer. The organ separation is produced by the degradation of the cell walls in the abscission zone, which is associated in grapes with an increase in the activity of cellulase and polygalacturonase (DENG et al., 2007). Abscission is a process highly regulated by phytohormones such as ethylene and jasmonates (ROHWER and ERWIN, 2008; ZHANG and ZHANG, 2009).

Ethephon (2-chloroethylphosphonic acid) is a plantgrowth regulator that, once inside the tissues, breaks down to liberate ethylene (MAYNARD and SWAM, 1963). Several studies conducted over 30 years ago, have shown that ethephon treatments previous to harvest lead to easier detachment of the fruits in different Vitis vinifera $L$ cultivars, increasing the presence of a dry stem scar in the abscission points (SZYJEWICZ et al., 1984). Both facts contribute to minimize physical damages and must losses in mechanical harvesting. However, the effects of ethephon are strongly influenced by concentration and time of treatment, cultivar differences and seasonal conditions (Peterson and HedBerg, 1975; El-ZefTAWI, 1982; SzYJEWICZ et al., 1984).

Jasmonates are a group of phytohormones, including jasmonic acid, methyl jasmonate and closely-related analogues, which are involved in numerous physiological plant processes (GROSS and PARTHIER, 1994; ROHWER and ERWIN, 2008) specifically stress responses, senescence and abscission of leaves and fruits. Methyl jasmonate might be a useful abscission agent in citrus (HARTMOND et al., 2000), but its efficacy seems to be lower than ethylene releasing compounds as ethephon in other plants (BURNS et al., 2008). FIDELIBUS et al. (2007) and GONZÁLEZ-HERRÁNZ et al. (2009) have shown that methyl jasmonate selectively induces abscission of mature grape berries and promotes dry stem scars on the abscission zone, demonstrating that these effects are dose dependant.

As adverse effects, the use of fruit-loosening agents at relatively high concentrations can produce undesirable defoliation (EL-ZEFTAWI, 1982; HARTMOND et al., 2000) or excessive natural detachment of fruits before harvest, which leads to significant yield losses (FIDELIBUS et al., 2007). Ethylene releasing compounds can delay budbreak and reduce vegetative growth the next spring (EIRS and CELIK 1981).

Interactions between phytohormones could substantially affect abscission. Several ethylene-independent, ethylene-promoted or ethylene-antagonised jasmonate 
responses have been discovered at physiological and genetic levels (ROHWER and ERWIN, 2008). Methyl jasmonate application was shown to enhance ethylene production in apple (SANIEWSKI et al., 1987) and citrus fruit (HARTMOND et al., 2000), while in other crops, as olive, no increases or even decreases in ethylene production have been reported (SANZ et al., 1993). ABELES et al. (1989) suggested that the abscission processes initiated by methyl jasmonate are independent of ethylene production within the tissue. In any case, possible additive or synergistic effects between abscission agents could be exploited in combined treatments to facilitate mechanical harvesting.

The objective of this study was to evaluate the additive and interaction effects of ethephon and methyl jasmonate applications on fruit detachment force in different seasonal conditions, and their potential use for improving mechanical harvesting of 'Verdejo' wine grapes.

\section{III.4. Material and Methods}

A field trial was carried out in 2009, 2010 and 2011, in a cv. 'Verdejo'/110 Richter vineyard located in Rueda Appellation d'Origine area (North-Central Spain). 'Verdejo' is a white grape cultivar, native from Rueda, which produce famous aromatic wines. The vineyard was planted in 2003 at $3.0 \times 1.5 \mathrm{~m}\left(2222\right.$ vines $\left.^{-h^{-1}}\right)$. Vines are pruned to a double Guyot system, leaving twenty buds in each, and are grown in trellis under irrigation, according to the standard practice in the zone. The soil is sandy and deep, with basic $\mathrm{pH}$ and low contents of organic matter.

Temperature and precipitation data were provided by the weather station of Rueda (Valladolid), located near the field trial. Mean air temperature was $11.1^{\circ} \mathrm{C}$ in $2009,11.9^{\circ} \mathrm{C}$ in 2010 and $12.8^{\circ} \mathrm{C}$ in 2011 . During these growing seasons, there were neither late frosts nor remarkable attacks of pests or diseases.

Different treatments were compared, resulting from combination in a fully crossed factorial experiment of two doses of ethephon ( 0 and $\left.1000 \mathrm{mg} \cdot \mathrm{L}^{-1}\right)$ with two doses of methyl jasmonate ( 0 and $20 \mathrm{mmol} \cdot \mathrm{L}^{-1}$ ) in 2009, and with three doses of methyl jasmonate $\left(0,20\right.$ and $\left.40 \mathrm{mmol} \cdot \mathrm{L}^{-1}\right)$ in 2010 and $2011.1 \mathrm{mmol} \cdot \mathrm{L}^{-1}$ methyl jasmonate approximately corresponds to $224 \mathrm{mg} \cdot \mathrm{L}^{-1}$. Solutions consisted of Ethrel 48 (ethephon $48 \%$ w/v, Nufarm España SA) and methyl jasmonate (95\% purify, SigmaAldrich). All solutions included $P G$ Supermojante $1 \% \mathrm{v} / \mathrm{v}$ (alquilphenol ethoxilated/propoxilated $99.6 \%$ w/w; Dwo AgroSciences Iberica, SA) as wetting agent. 
Experimental design was completely randomized with five replications and one plant per replication. Treatments were applied to the clusters until runoff with a hand sprayer (average around $0.25 \mathrm{~L}$ solution per vine) when grapes had amassed sufficient

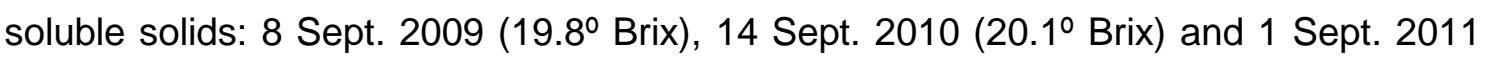
(23.1ํ Brix). In 2009 and 2011, there were no rainfalls from sprayings to harvest whereas, in 2010, 14.4 and $5.4 \mathrm{~mm}$ were registered 3 and 4 days after the applications, respectively.

One cluster per replication was taken carefully 2, 4, 6 and 8 days after treatments to measure the force required to detach each berry from the rachis. Sampled clusters were cut in three portions: top, middle and bottom part, and from each one, two berries were cut with pedicel to measure fruit detachment force (FDF). Each berry was placed in a jig attached for a force gauge (DS2-N5; Imada, Northbrook, IL) and force parallel to the fruit axis was applied to the rachis until it detached from the berry, at which time peak force was recorded.

The condition of the surface of the abscission zone (presence of a dry stem scar) in the berries detached in the course of making FDF measurements was checked 8 days after treatments, using a binocular magnifying glass. Further, in 2010 and 2011, a cluster from controls and vines cotreated with ethephon and 20 or $40 \mathrm{mmol} \mathrm{L}-1$ methyl jasmonate was shaken by hand at harvest. Then, detached berries were classified depending on the presence or not of scar tissue (dry or wet) in the abscission zone.

To assess potential yield losses associated with treatments, in 2010 and 2011 one cluster per replication was randomly selected after the sprayings and was loosely enclosed in plastic mesh bags to catch any berries that might abscise. The weight percentage of dropped berries was determined. Possible leaf yellowing and/or leaf abscission in treated plants were observed until the end of growing season. Vines were monitored next spring for date of bud break.

At harvest (16 Sept. 2009, 22 Sept. 2010 and 11 Sept. 2011), 50 berries were randomly collected and weighed in each experimental treatment. Total soluble solids content, total acidity and $\mathrm{pH}$ were determined in the must obtained from each sample according to the official methods of analysis established by the European Commission (EEC 2676/90 Regulations; European Commission 1990). Absorbances at $420 \mathrm{~nm}$ (UV/VIS spectrophotometer Jasco V-530) also were measured. 
Data were subjected to factorial analysis of variance (ANOVA) using SAS statistical software (SAS Inst., Cary, NC). The separation of means was accomplished using the Least Significant Difference (LSD) test.

\section{III.5. Results and Discussion.}

The factorial analysis of variance (Table III.1) shows that the fruit detachment force (FDF) and the condition of the surface of the abscission zone in berries detached were significantly modified by conditions during the growing season and experimental treatments. There were strong seasonal differences between 2009 versus 2010 and 2011 (Tables III.1 and III.2), probably due to differences in environmental conditions that prevailed at or after applications, particularly to differences in temperature and soil moisture levels (PETERSON and HEDBERG, 1975). Within each year, FDF decreased throughout the course of the study whether the clusters were treated with abscission agents or not (Table III.2).

Table III.1. Mean squares of factorial analysis of variance of data ontained from ethephon (ET) and methyl jasmonate (MeJA) sprayings at different days after treatments (DAT) in 2009, 2010 and 2011.

\begin{tabular}{|c|c|c|c|c|c|c|c|c|c|}
\hline \multirow{2}{*}{ Parameter/Time } & \multicolumn{9}{|c|}{ Source of variation } \\
\hline & Model & & Year & & ET & MeJA & & $\mathrm{ET}^{*} \mathrm{MJ}$ & Error \\
\hline \multicolumn{10}{|c|}{ Weight of dropped berries (\%) } \\
\hline From 0 to 8 DAT & 44.15 & & 22.25 & & 46.54 & 59.06 & & 44.18 & 26.60 \\
\hline \multicolumn{10}{|c|}{ Fruit Detachment Force } \\
\hline 4 DAT & 2.560 & ** & 7.829 & ** & 1.322 & ** 0.105 & & 0.056 & 0.100 \\
\hline 6 DAT & 2.867 & * & 9.092 & * & 1.383 & * 0.349 & & 0.046 & 0.120 \\
\hline 8 DAT & 3.838 & * & 12.955 & * & 1.006 & * 1.667 & * & 0.026 & 0.137 \\
\hline \multicolumn{10}{|c|}{ Berries with dry stem scar (\%) } \\
\hline 8DAT & 2036.1 & ** & 1820.1 & ** & 4584.1 & ** 2374.6 & $* *$ & $1272.8^{* *}$ & 168.8 \\
\hline \multicolumn{10}{|l|}{ Berry weight } \\
\hline 8 DAT & 0.428 & * & 1.347 & ** & 0.003 & 0.202 & & 0.086 & 0.127 \\
\hline \multicolumn{10}{|l|}{ Must composition } \\
\hline Brix & 22.445 & * & 72.349 & * & 0.808 & 0.035 & & 4.381 & 3.138 \\
\hline $\mathrm{pH}$ & 0.049 & * & 0.099 & * & 0.025 & 0.018 & & 0.035 & 0.018 \\
\hline Total Acidity & 6.554 & * & 21.160 & * & 0.028 & 1.511 & * & 1.261 & 0.472 \\
\hline Absorbance 420 nm & 0.216 & & 0.591 & * & 0.001 & 0.100 & & 0.472 & 0.179 \\
\hline
\end{tabular}

* Significant $p<0.05 ;{ }^{* *}$ significant $p<0.01$. 
Ethephon spraying reduced FDF 4 days after treatment $(p<0.05)$ in all studied seasons (Fig. III.1), maintaining values below those of untreated controls until harvest (Table III.2). In concordance, EL-ZEFTAWI (1982) observed that dose of $1000 \mathrm{mg} \cdot \mathrm{L}^{-1}$ ethephon was effective to reduce the cluster detachment force 5-7 days after treatments in various wine grape cultivars.

Methyl jasmonate treatments presented a minor and later effect on FDF than those of ethephon. Differences between treated and untreated vines were not significant in 2010, whereas in $2009\left(20 \mathrm{mmol} \cdot \mathrm{L}^{-1}\right)$ and $2011\left(40 \mathrm{mmol} \cdot \mathrm{L}^{-1}\right)$ methyl jasmonate declined FDF from 6-8 days after the sprayings, with respect to controls. These FDF reductions did not reach the levels of $75-80 \%$ observed by FIDELIBUS et al., (2007) in raisin grapes and HARTMOND et al. (2000) in citrus, using similar doses of methyl jasmonate.

Table III.2. Mean values of fruit detachment force and proportion of abscised berries exhibiting a dry stem scar, obtained with ethephon (ET) and methyl jasmonate (MeJA) applications in different days after treatments (DAT).

\begin{tabular}{|c|c|c|c|c|c|c|c|}
\hline \multirow[t]{2}{*}{ Year } & \multirow{2}{*}{$\begin{array}{l}\text { ET } \\
\left(\mathrm{mg} \cdot \mathrm{L}^{-1}\right)\end{array}$} & \multirow{2}{*}{$\begin{array}{l}\text { MeJA } \\
\left(\mathrm{mmol} \cdot \mathrm{L}^{-1}\right)\end{array}$} & \multicolumn{4}{|c|}{ Fruit Detachment Force $(\mathrm{N})$} & \multirow{2}{*}{$\begin{array}{r}\begin{array}{r}\text { Dry scar } \\
\text { berries }(\%)\end{array} \\
\text { 8DAT }\end{array}$} \\
\hline & & & 2 DAT & 4 DAT & 6DAT & 8DAT & \\
\hline \multirow[t]{4}{*}{2009} & 0 & 0 & $1.250 \mathrm{a}$ & $1.358 \mathrm{a}$ & $1.718 \mathrm{a}$ & $1.017 \mathrm{a}$ & $0.0 \mathrm{a}$ \\
\hline & & 20 & $1.189 \mathrm{a}$ & $1.192 \mathrm{a}$ & $1.123 \mathrm{~b}$ & $0.824 a$ & $0.0 \mathrm{a}$ \\
\hline & 1000 & 0 & $1.313 \mathrm{a}$ & $1.188 \mathrm{a}$ & $0.964 a$ & $0.897 \mathrm{a}$ & $0.0 \mathrm{~b}$ \\
\hline & & 20 & $1.200 \mathrm{a}$ & $0.951 \mathrm{a}$ & $0.774 \mathrm{a}$ & $0.555 \mathrm{~b}$ & $33.3 \mathrm{a}$ \\
\hline \multirow[t]{6}{*}{2010} & 0 & 0 & $2.283 \mathrm{a}$ & $1.995 \mathrm{a}$ & $1.955 \mathrm{a}$ & $2.111 \mathrm{a}$ & $0.0 \mathrm{a}$ \\
\hline & & 20 & $1.979 \mathrm{a}$ & $2.131 \mathrm{a}$ & $2.225 \mathrm{a}$ & $2.060 \mathrm{a}$ & $0.0 \mathrm{a}$ \\
\hline & & 40 & $2.122 \mathrm{a}$ & $2.097 \mathrm{a}$ & $1.870 \mathrm{a}$ & $1.858 \mathrm{a}$ & $0.0 \mathrm{a}$ \\
\hline & 1000 & 0 & $2.102 \mathrm{a}$ & $1.700 \mathrm{a}$ & $1.910 \mathrm{a}$ & $1.782 a b$ & $0.0 \mathrm{a}$ \\
\hline & & 20 & $2.267 \mathrm{a}$ & $1.884 \mathrm{a}$ & $2.101 \mathrm{a}$ & $2.081 \mathrm{a}$ & $0.0 \mathrm{a}$ \\
\hline & & 40 & $2.127 \mathrm{a}$ & $1.689 \mathrm{a}$ & $1.834 \mathrm{a}$ & $1.745 b$ & $3.3 \mathrm{a}$ \\
\hline \multirow[t]{6}{*}{2011} & 0 & 0 & $2.813 \mathrm{a}$ & $2.537 \mathrm{a}$ & $2.244 \mathrm{a}$ & $2.545 \mathrm{a}$ & $0.0 \mathrm{a}$ \\
\hline & & 20 & $2.957 \mathrm{a}$ & $2.349 \mathrm{a}$ & $2.439 \mathrm{a}$ & $2.554 \mathrm{a}$ & $0.0 \mathrm{a}$ \\
\hline & & 40 & $2.420 \mathrm{a}$ & $2.282 \mathrm{a}$ & $2.438 \mathrm{a}$ & $1.873 \mathrm{~b}$ & $10.0 \mathrm{a}$ \\
\hline & 1000 & 0 & $2.363 a b$ & $2.166 \mathrm{a}$ & $2.154 \mathrm{ab}$ & $2.272 \mathrm{a}$ & $0.0 \mathrm{c}$ \\
\hline & & 20 & $2.922 \mathrm{a}$ & $2.378 \mathrm{a}$ & $2.414 \mathrm{a}$ & $2.202 \mathrm{a}$ & $20.0 \mathrm{~b}$ \\
\hline & & 40 & $2.311 \mathrm{~b}$ & $1.853 \mathrm{a}$ & $1.776 \mathrm{~b}$ & $1.380 \mathrm{~b}$ & $60.0 \mathrm{a}$ \\
\hline
\end{tabular}

Within years and ethephon treatments, means with different letters are significantly different $(p<0.05$, LSD test). 


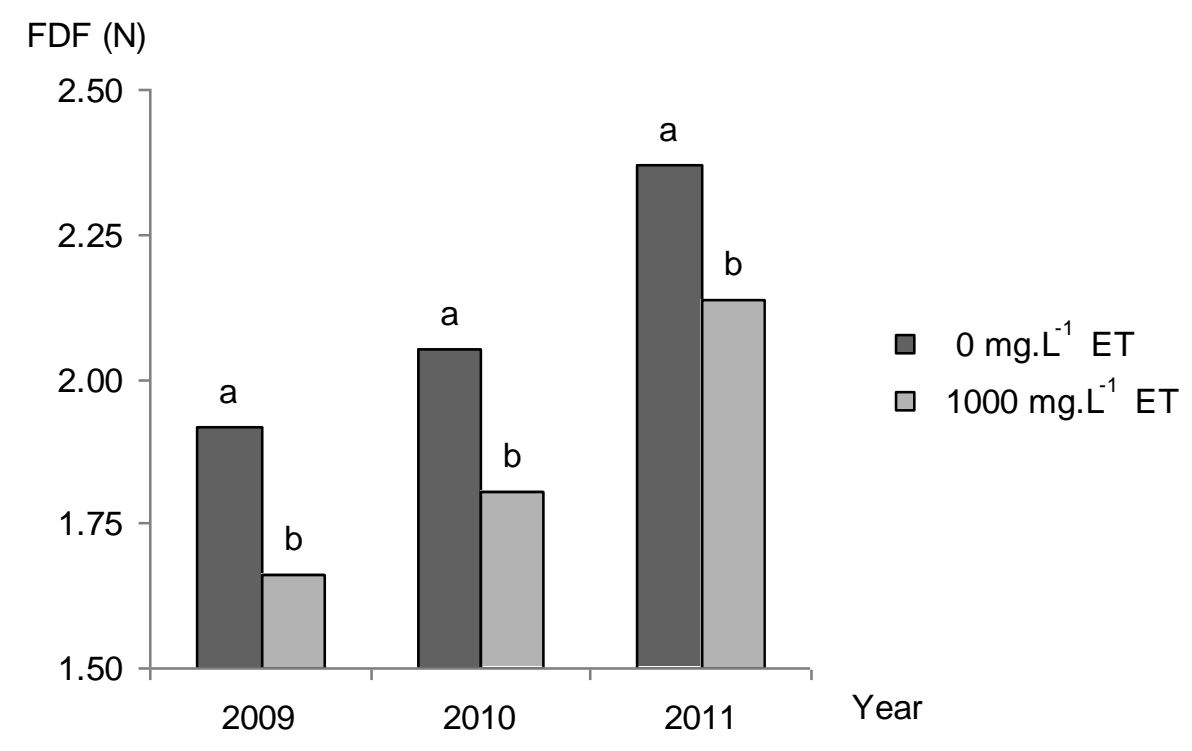

Figure III.1. Comparison of means of fruit detachment force (FDF) registered 4 days after applications in plants treated and untreated with ethephon (ET) in 2009, 2010 and 2011.

The lack of response to methyl jasmonate on FDF in 2010 can be associated with the rainfall registered 3 and 4 days after treatments $(19.8 \mathrm{~mm}$ in total), which might have washed part of the product from the clusters. This precipitation may have eliminated the effects of methyl jasmonate but not those of ethephon, since they act faster (Fig. III.1). Not only the rainfall after spraying (MORTENSEN, 1980) but also an incomplete cover of product in the grapes or an insufficient maturity level of fruits when they receive the application may affect the efficacy of abscission agents (FIDELIBUS et al., 2007).

The additive effect reflected in ANOVA (Table III.1) made the combination of ethephon (1000 $\left.\mathrm{mg} \cdot \mathrm{L}^{-1}\right)$ and methyl jasmonate more effective than either agent alone. Really,the lowest FDF values registered 8 days after treatments in the trial corresponded to cotreated plants (Table III.2). The declines accounted for $47.2 \%$ in 2009 (20 mmol. $\mathrm{L}^{-1}$ methyl jasmonate) and $45.8 \%$ in 2011 (40 mmol. $\mathrm{L}^{-1}$ methyl jasmonate), relative to untreated controls. These reductions could minimize physical damage on mechanically harvested grapes.

Although methyl jasmonate treatments were shown to increase ethylene production in different crops (SANIEWSKI et al., 1987; HARTMOND et al., 2000), the abscission processes initiated by methyl jasmonate could be due, at least in part, to a direct effect of the hormone, independent of ethylene production within the tissue, on polysaccharide metabolism and mechanical weakening of cell walls in the abscission 
zone (ABELEs et al., 1989; SANZ et al., 1993). The additive effect between methyl jasmonate and ethephon we have detected might be a result both of an enhancing of ethylene production and an ethylene-independent action.

Data of the condition of the surface of the abscission zone in the berries detached for FDF measurements showed that ethephon or methyl jasmonate had no effects on this parameter applied separately (Table III.2). Despite this fact, it is interesting to note that combined treatments with both plant growth regulators significantly increased the presence of a dry stem scar in berries detached up to 8 days after the application with respect to the controls (Table III.2), reaching accumulated values up to $60 \%$ in 2011. When the clusters cotreated with methyl jasmonate (20 and $\left.40 \mathrm{mmol} \cdot \mathrm{L}^{-1}\right)$ and ethephon $\left(1000 \mathrm{mg} \cdot \mathrm{L}^{-1}\right)$ were shaken by hand at harvest, the percentages of detached berries presenting scar tissue in the abscission zone were greater than $50 \%$ (Fig. III.2). GONZÁLEZ-HERRÁNZ et al. (2009) in cv. 'Thompson Seedless', and MORRIS and CAWTHON (1981) in cv. 'Concord', have reported increase on the presence of dry stem scars after simple applications of methyl jasmonate (doses above $\left.10 \mathrm{mg} \cdot \mathrm{L}^{-1}\right)$ and ethephon (400 $\left.\mathrm{mg} \cdot \mathrm{L}^{-1}\right)$ respectively. There are no references in the literature about combined effects of both abscission agents on this variable.

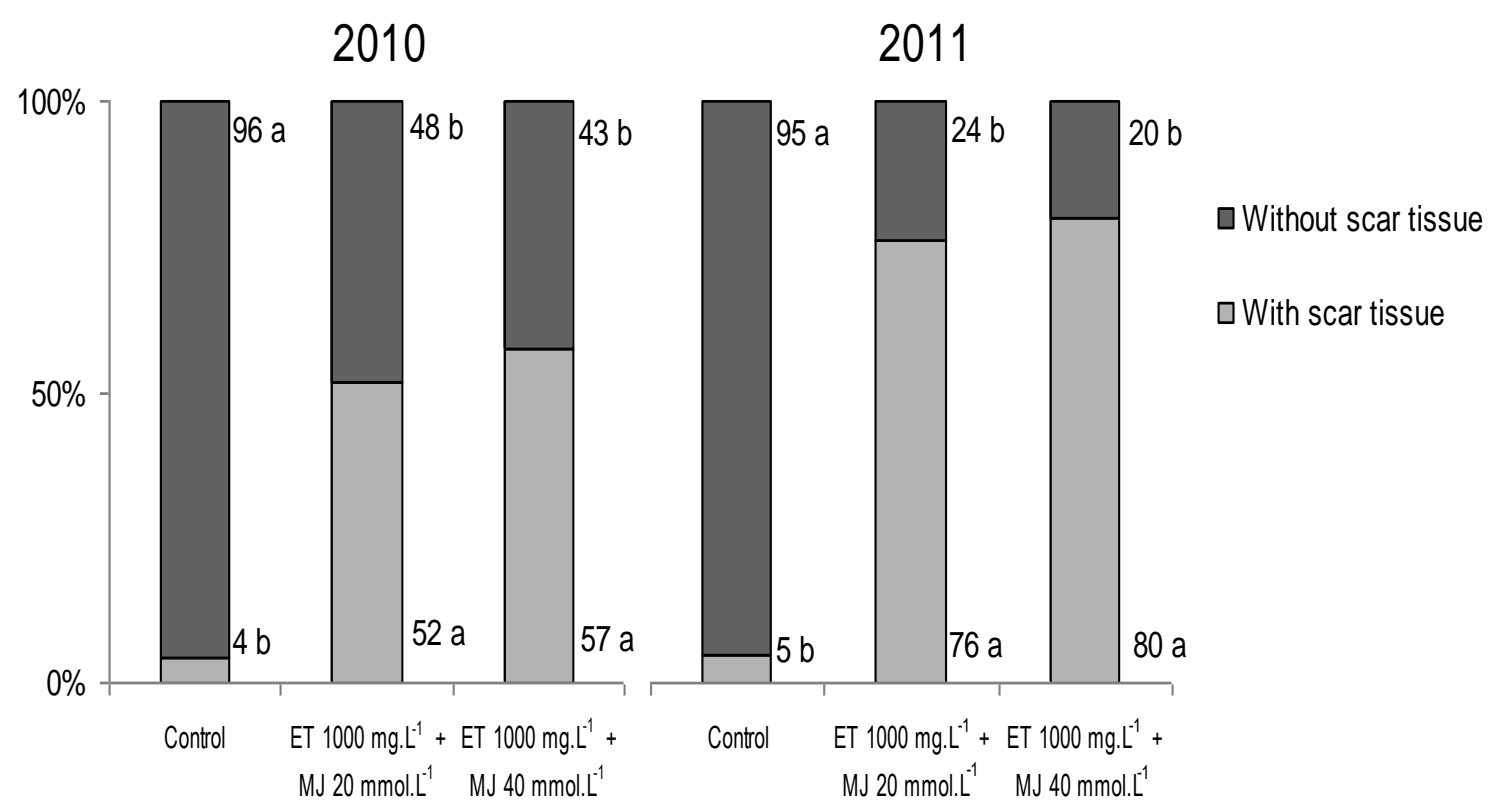

Figure III.2. Percentage of detached berries presenting scar tissue in the abscission zone, when the clusters were shaken by hand at harvest, in different experimental treatments combining ethephon (ET) and methyl jasmonate (MJ) applications. Within years and colours, means followed by a different letter are significantly different $(p<0.05$, LSD test). 
Wet stem scars provide an entry point for pathogenic microorganisms (BALLINGER and NESBITT, 1982; Kou et al., 2007) and enable juice to leak from the berries, promoting undesirable oxidation and fermentative processes before they are delivered to the winery (MEYER, 1969). The dry scars prevent these problems and, on the other hand, allow the harvest of individual berries, having minimal mechanical damage. Therefore, the promotion of dry stem scars by combined application of methyl jasmonate and ethephon is highly interesting.

The average of dropped berries, collected in net bags from spraying to harvest, represented between $0.71 \%$ (year 2010) and $1.35 \%$ (2011) of total weight of the clusters, considering the full field test. The ANOVA of these values was not significant $(p<0.05)$ for experimental treatments (Table III.1). Thus, the abscission agents did not produce representative yield losses if plants are harvested until 8 days after treatments. The appearance of vines treated with methyl jasmonate and ethephon and control vines were similar. No leaf yellowing, leaf abscission or delay in bud break date in the next spring were observed after the application of abscission agents (data not shown).

Berry weight and must composition parameters have shown significant interannual differences $(P<0.05)$, but have been little affected by the abscission agents applied, except for total acidity (Table III.1). The juices from berries treated in 2011 with $40 \mathrm{mmol} \cdot \mathrm{L}^{-1}$ methyl jasmonate had significant higher titratable acidity than untreated berries (Fig. III.3). The results obtained for this variable, in wine grapes, are consistent with those of studies on postharvest applications in stored fruits and vegetables where methyl jasmonate have contributed to maintain the acidity levels (WANG, 1998; JIN et al., 2006; GHASEMNEZHAD and JAVAHERDASHTI, 2008). On the other hand, FIDELIBUS et al., (2007) found that 'Cabernet Sauvignon' berries treated with $4500 \mathrm{mg} \cdot \mathrm{L}^{-1}$ methyl jasmonate had less total acidity than nontreated controls 14 days after the sprayings, while treatment had no significant effects in 'Merlot'.

Since ethephon and methyl jasmonate were applied late, probably they did not significantly affect ripening processes as when applied at veraison (GALLEGOS et al., 2006; GONZÁLEZ et al., 2011; RUIZ-GARCíA et al., 2012), and therefore they have not impact on must composition parameters at harvest. Responses observed to ethephon applications near the harvest have been little and variable, depending on cultivar and seasonal differences (MORRIS and CAWTHON, 1981; EL-ZEFTAWI,1982). 


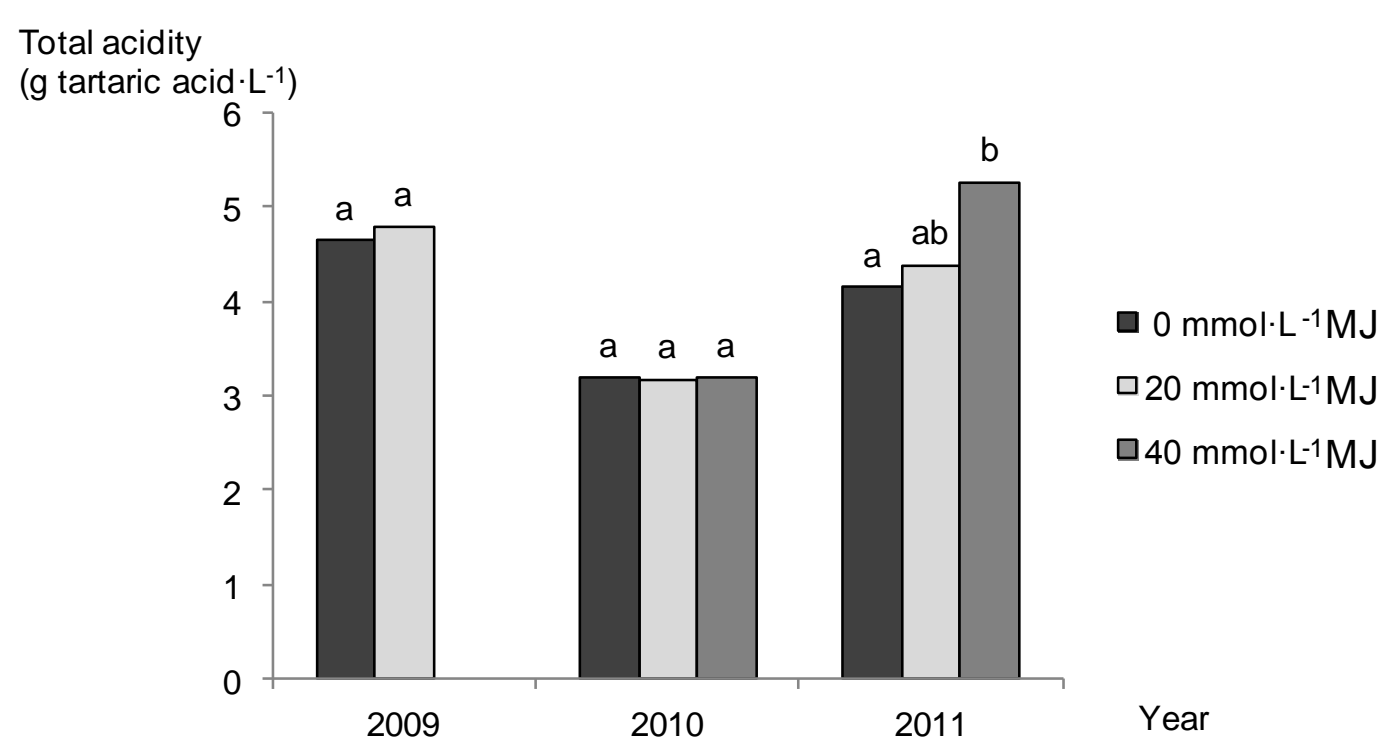

Figure III.3. Effect of different doses of methyl jasmonate on total acidity of must in the three years studied.

In conclusion, fruit detachment force in 'Verdejo' grapevines has been significantly reduced by cotreatments with ethephon and methyl jasmonate applied 8 days before harvest, without causing yield losses, defoliation or delay in bud break the next spring. Moreover, the combined applications have promoted the formation of dry stem scars in the abscission zones of the berries. For these reasons, the preharvest treatment combining these two fruit-loosening agents is potentially useful as a tool for enhancing wine quality in mechanically harvested vineyards. They can enable less aggressive harvesting, leading to reduction of fruit damage, less material as rachis and leaves are sent to the winery, and less volume of juice is released during the process.

Practical treatments of abscission agents to the canopy (fruiting zone) might not be as effective as sprayings applied directly over the clusters have resulted in our study. Further research should be carried out to provide abscission agent concentrations necessary for consistent fruit loosening in practical conditions at multiple growing sites. Moreover, application of fruit loosening agents should be tested in larger scale mechanically harvested trials, to determine the optimal harvester settings necessary to achieve high fruit removal with low fruit damage, as function of the specific characteristics of treated vines.

Evaluation of musts and wines obtained from mechanically harvested grapes, treated and untreated with ethephon and methyl jasmonate, must be made to demonstrate these abscission agents can effectively improve wine quality. It will be especially important to assess oxidative stability and aroma characteristics. 


\section{III.6. References}

Abeles, F.B., W.L. Hershberger and L. Dunn 1989: Hormonal regulation and intracellular localization of a 33-kDa cationic peroxidase in cucumber cotyledons. Physiol. Plant. 89, 664-448.

Baldini, E. and C. Intrieri 2004: Viticoltura meccanizzata, Edagricole, Bologna, Italy.

BALLINGER, W.E. and W.B. NESBITT 1982: Postharvest decay of muscadine grapes ('Carlos') in relation to storage temperature, time and stem condition. Am. J. Enol. Vitic. 33,173-175.

Burns, K.J., L. Ferguson, K. Glozer, H.W. Krueger and C.R. Rosecrance 2008 : Screening fruit loosening agents for black ripe processed table olives. HortScience 43, 1449-1453.

Carrara, M., P. Catania, F. Pipitone, M. Vallone and M. Salvia 2007: Assessment of the pedicel detaching and crushing forces of grape berries to determine the right mechanical harvesting period. Rivista di Ingegneria Agraria 3, 33-37.

CATANiA, P., M. VAlLONE and F. PiPITONE 2009: Analysis of the main factors influencing the quality of wine from mechanical harvested grapes. Rivista di Ingegneria Agraria 4, 35-38.

Deng, Y., Y. Wu, Y. LI, M. YANG, C. SHI and C. ZHENG 2007: Studies of postharvest berry abscission of 'Kyoho' table grapes during cold storage and high oxygen atmospheres. Postharvest Biol.Technol. 43, 95-101.

EIRS, A. and H. CELIK 1981: Effects of some plant growth regulators on bud burst and rooting of Vitis vinifera L. cv. Chaush cuttings. Am. J. Enol. Vitic. 32, 122-124.

EL-ZEFTAWI, B.M. 1982: Effects of ethephon on clusters loosening and berry composition of four wine cultivars. J. Hortic. Sci. 57, 457-463.

EUROPEAN COMMISION 1990: Regulation (EEC) № 2676/90 of 17/09/1990. Community methods for the analysis of wines. Official Journal of the European Communities L272 (3/10/1990), 0001-0192.

FidelibuS, M.W., K.A. CATHLine and J.K. BuRns 2007: Potential abscission agents for raisin, table and wine grapes. HortScience 42, 1626-1630.

Gallegos, J.I., R. GonzÁlez, M.R. GonzÁlez and P. MARTín 2006: Changes in composition and colour development of 'Tempranillo' grapes during ripening induced by ethephon treatments at véraison. Acta Hortic. 727, 505-512.

GHASEMNEZHAD, M. and M. JAVAHERDASHTI 2008: Effect of Methyl jasmonate treatment on antioxidant capacity, internal quality and postharvest life of raspberry fruit Caspian J. Env. Sci. 6, 73-78. 
GONZÁLEZ, R., M.R. GONZÁLEZ and P. MARTíN 2011: Effects of ethephon on vegetative growth and fruit composition of 'Verdejo' grapevines. Agrochimica 55, 139-146.

GonzÁlez-HerránZ, R., K.A. CATHLine, M.W. Fidelibus and J.K. BuRns 2009: Potential of methyl jasmonate as a harvest aid for 'Thompson Seedless' grapes: Concentration and time needed for consistent berry loosening. HortScience 44, 1330-1333.

GROss, D. and B. PARTHIER 1994: Novel natural substances acting in plant growth regulation. J. Plant Growth Regul. 13, 93-114.

HaRtMOND, U., R. YuAN, J.K. BuRnS, A. GRANT and W.J. KENDER 2000: Citrus fruit abscission induced by methyl- jasmonate. J. Amer. Soc. Hort. Sci. 125, 547-552.

JiN, P., Y.H. Zheng, C.M. Cheng, H.Y. GAO, W.X. Chen and H.J. Chen 2006: Effect of methyl jasmonate treatment on fruit decay and quality in peaches during storage at ambient temperature. Acta Hortic. 712, 711-716.

KOU, L., Y. LUO, D. WU and X. LIU 2007: Effects on mild heat treatment on microbiological growth and product quality of packaged fresh cut table grapes. J. Food Sci. 72, 567-573.

MAYNARD, J.A. and J.M. SWAM 1963: Organophosphorus compounds. Aust. J. Chem. $16,596-608$.

MEYER, J. 1969: Effect of Fruit Cane Severance of Grapevines on Must and Wine Yield and Composition. Am. J. Enol. Vitic. 20, 108-117.

MORRIS, J.R. and D.L. CAWTHON 1981: Effects of ethephon on maturation and postharvest quality of Concord grapes. J. Am. Soc. Hort. Sci. 106, 293-295.

MORTENSEN, J.A. 1980: Effects of ethephon on ease of harvest of muscadine grapes. Proc. Fla. State Hort. Soc. 93, 143-145.

NAGEL, C.W. and W.R. GRABER 1988: Effect of must oxidation on quality of white wines. Am. J. Enol. Vitic. 39, 1-4.

Peterson, J.R. and P.R. HedBerg 1975: Some factors affecting the response of grapevines to ethephon. Sci. Hort. 3, 275-283.

ROHWER, C.L. and J.E. ERWIN 2008: Horticultural applications of jasmonates: A review. J. Hort. Sci. Biotech. 83, 283-304.

Ruiz-García, Y., I. Romero-Cascales, R. Gil-Muñoz, J.I. FernándeZ-FernándeZ, J.M. LÓPEZ-ROCA and E. GÓMEZPLAZA 2012: Improving grape phenolic content and wine chromatic characteristics through the use of two different elicitors: methyl jasmonate versus benzothiadiazole. J. Agric. Food. Chem. 60, 1283-1290. 
SANIEWSKI, M., J. CZAPSKI, J. NowACKI and E. LANGE 1987: The effect of methyl jasmonate on ethylene and 1-aminocyclopropane-1-carboxylic acid production in apple fruits. Biol. Plant. 29, 199-203.

SANZ, L., J.C. FernándeZ-Maculet, E. GómeZ, B. ViOQue and J.M. Olias 1993: Effect of methyl jasmonate on ethylene biosynthesis and stomatal closure in olive leaves. Phytochemistry 33, 285-289.

SZYJEWICZ, E., N. ROSNER and W.M. KLIEWER 1984: Ethephon (2chloroethylphosphonic acid, Ethrel, Cepa) in viticulture - A Review. Am. J. Enol. Vitic. 35, 117-123.

WALG, O. 2007: Taschenbuch der Weinbautechnik. Lehrbuch und Nachschlagewerk. Fachverlag Dr. Fraund, Mainz; Germany (In German).

WANG, C.Y. 1998: Methyl jasmonate inhibits postharvest sprouting and improves storage quality of radishes. Postharvest Biol.Technol. 14, 179-183.

ZHANG, Y.L. and R.G. ZHANG 2009: Effects of ABA content on the development of abscission zone and berry falling after harvesting of grapes. Agric. Sci. China. 8, 59-67. 
IV.ENSAYO 2 


\section{ENSAYO 2}

\section{Methyl Jasmonate and 1-Aminocyclopropane-1-Carboxylic Acid Interact to Promote Grape Berry Abscission.}

(Metil jasmonato y ácido 1-aminociclopropano-1-carboxilico interactuan para promover la abscisión de uva).

Autores: Lorena Uzquiza ${ }^{1}$, Pedro Martin ${ }^{1}$, James R. Sievert ${ }^{2}$, Mary Lu Arpaia ${ }^{2}$, y Matthew W. Fidelibus ${ }^{3}$.

${ }^{1}$ Departamento de Producción Vegetal y Recursos Forestales, Universidad de Valladolid, Av. Madrid 57, C.P 34004, Palencia, Spain.

${ }^{2}$ Department of Botany and Plant Sciences, University of California, Riverside, CA 92521.

${ }^{3}$ Department of Viticulture and Enology, University of California, Davis, CA 95616.

Publicado en: American Journal of Enology and Viticulture, 65(4): 504-509. Año: 2014

\section{IV.1.Resumen}

La aplicación de metil jasmonato (MeJA) o etefón, agente liberador de etileno, en uva cv. Thompson seedless puede reducir la fuerza de desprendimiento del fruto (FDF) y promover el desarrollo de cicatrices secas en las zonas de abscisión de las bayas, mejorando posiblemente la calidad de la vendimia mecanizada. Sin embargo, la cantidad de MeJA o etefón necesaria para estimular la abscisión podría ser excesivamente cara y dejar una cantidad de residuos excesiva en el producto. Por ello, se han llevado a cabo estudios para determinar si el MeJA podría interactuar con el ácido 1-aminociclopropano-1-carboxílico (ACC), precursor bioquímico del etileno, para promover los procesos relacionados con la abscisión y posiblemente reducir la cantidad de MeJA necesaria. En un ensayo preliminar, el MeJA (672 y 1,344 mg/L) interactuó con el ACC (500 y 1,000 mg/L) para reducir la FDF entre un 25 y un $70 \%$ 
comparado con las bayas sin tratar. Sin embargo, MeJA y ACC no interactuaron sobre la caída prematura de frutos previa a la cosecha, aunque los tratamientos con 672 ó $1.344 \mathrm{mg} / \mathrm{L}$ MeJA causaron un 16-23\% de caída en los 3 días posteriores al tratamiento (DAT). En un segundo ensayo, las bayas tratadas con MeJA, solo o con ACC, mostraron un máximo de producción de etileno 1 DAT, que se mantuvo elevada a los 2 DAT y se redujo rápidamente después, mientras que las bayas tratadas solo con ACC mantuvieron una producción moderadamente elevada durante los 10 días de duración del estudio. Los tratamientos con ACC y MeJA redujeron la FDF desde 1 ó 2 DAT, respectivamente. A los 2 DAT, las bayas comenzaron a desprenderse de los racimos tratados con MeJA, independientemente de si eran tratadas también con ACC o no, pero a los 3, 4, y 10 DAT, ACC y MeJA interactuaron para promover una considerable caída prematura de uvas. Además, la combinación de ACC y MeJA también promovió el desarrollo de una cicatriz seca en la zona de abscisión. Por todo ello, la aplicación combinada de MeJA y ACC es más efectiva estimulando los procesos relacionados con la abscisión de la uva que la aplicación de cada compuesto por separado.

Palabras clave: abscisión, reguladores del crecimiento, vendimia mecanizada, Vitis vinifera L.

\section{IV.2.Summary.}

The application of methyl jasmonate (MeJA) or ethephon, an ethylene-releasing agent, to Thompson Seedless grapes can reduce fruit detachment force (FDF) and promote the development of dry stem scars on berries, possibly improving the quality of machine-harvested grapes. However, the amount of MeJA or ethephon needed to stimulate abscission may be prohibitively expensive and result in excessive residues. Thus, experiments were conducted to determine whether MeJA might interact with 1aminocyclopropane-1-carboxylic acid (ACC), a natural biochemical precursor of ethylene, to promote abscission-related processes and possibly reduce the amount of MeJA needed. In a preliminary trial, MeJA (672 and 1,344 mg/L) interacted with ACC ( 500 and $1,000 \mathrm{mg} / \mathrm{L}$ ) to reduce FDF by 25 to $70 \%$ compared with untreated grapes. However, MeJA and ACC did not interact to affect preharvest fruit drop, although treatment with 672 or $1.344 \mathrm{mg} / \mathrm{L}$ MeJA caused 16 to $23 \%$ drop by 3 days after treatment (DAT). In a second trial, grapes treated with MeJA, singly, or with ACC, produced ethylene which peaked at 1 DAT, remained elevated at 2 DAT, and declined 
rapidly thereafter, whereas grapes treated only with ACC maintained moderately elevated ethylene production throughout the 10-day study. Treatment with ACC or MeJA reduced FDF within 1 or 2 DAT, respectively. By 2 DAT, berries began to abscise from MeJA-treated clusters, regardless of whether they were also treated with ACC, but on 3, 4, and 10 DAT, ACC and MeJA interacted to greatly promote preharvest fruit drop. Moreover, the combination of ACC and MeJA also promoted dry stem scar development. Thus, coapplication of MeJA and ACC is more effective at stimulating grape abscission-related processes than either compound applied singly.

Key words: abscission, mechanical harvesting, plant growth regulators, Vitis vinifera L.

\section{IV.3.Introduction}

Mature grape (Vitis vinifera L.) berries do not normally abscise, but they can be induced to do so with the application of certain plant growth regulators, including methyl jasmonate (MeJA) (FIDELIBUS and CATHLINE, 2010; FIDELIBUS et al., 2007) and ethephon (FERRARA et al., 2010; HEDBERG and GOODWIN, 1980). The stimulation of grape berry abscission results in some potentially beneficial effects, including a reduction in fruit detachment force (FDF) and an increase in the proportion of berries with dry stem scars, effects that could improve the quality of machine-harvested fruit (Fidelibus et al., 2007; GonZÁlez-HerRANZ et al., 2009, HEDBERG and GoOdWin, 1980, UZQUIZA et al., 2013a, 2013b). However, MeJA and ethephon are only effective grape abscission agents at relatively high concentrations) (FIDELIBUS and CATHLINE 2010, GonZALEZ-HERRANZ et al., 2009, UZQUIZA et al., 2013a, 2013b). Therefore, the high cost of MeJA and the potential for excessive residues, particularly of ethephon, could preclude their potential commercial use as grape abscission agents.

One strategy for improving the efficacy of abscission agents, and thereby potentially decreasing their required application rates, is to use them in combination (HOLM and WILSON, 1977; KENDER et al., 2001; UZQUIZA et al., 2013a, 2013b). The coapplication of MeJA and 5-chloro-3-methyl-4-nitro-1H-pyrazole (CMN-pyrazole) increased internal ethylene content and decreased FDF of oranges (Citrus sinensis L. [Osb.]) to a greater extent than was achieved by applying either agent singly (HOLM and WILSON 1977; KENDER et al., 2001). The effects that combinations of abscission agents may have on grape have been less studied, although combinations of ethephon $(1,000 \mathrm{mg} / \mathrm{L})$ and $\mathrm{MeJA}(4,480$ or $8,960 \mathrm{mg} / \mathrm{L})$ were generally more effective at reducing FDF and promoting dry stem scars on Verdejo grapes than either compound 
applied singly (UZQUIZA et al., 2013a). Even so, Verdejo was not nearly as responsive to abscission agents as some other grape cultivars such as Thompson Seedless (FIDELIBUS et al., 2007) so additional testing is needed to determine the potential benefit of combined treatments on responsive cultivars.

Exogenous application of jasmonates stimulates ethylene production in several fruits, including orange (HARTMOND et al., 2000, Kender et al., 2001), apple (Malus X domestica Borkh.) (FAN et al., 1998; SANIEWSKI et al., 1987a), tomato (Lycopersicon esculentum) (SANIEWSKI et al., 1987b), and strawberry (Fragaria x ananassa Duch) (MUKKUN and SINGH, 2009). Most of those studies focused on the physiology of fruit ripening with the exception of the work on oranges (HARTMOND et al., 2000, KENDER et al., 2001), which showed that the application of MeJA stimulated ethylene production by the fruit, which was followed by fruit abscission. MALLADI et al. (2012) provided indirect evidence that MeJA stimulates abscission of blueberry (Vaccinium spp.) fruits at least partly via ethylene action, as the coapplication of MeJA with aminoethoxyvinylglycine (AVG), an ethylene biosynthesis inhibitor, attenuated MeJA effects on abscission. However, MeJA still induced some abscission of blueberry, even when coapplied with AVG, which could suggest that MeJA may initiate some abscission processes independently of ethylene. This finding agrees with recently reported work showing that ethylene and jasmonic acid promote floral organ abscission via independent pathways in Arabidopsis thaliana (KIM et al., 2013).

To our knowledge, the physiology of MeJA-induced berry abscission has not been studied in grape, although such knowledge is needed to advance progress toward developing effective grape abscission agents. If MeJA stimulates grape abscission indirectly, via ethylene, then the coapplication of MeJA and 1aminocyclopropane-1-carboxylic acid (ACC), the biochemical precursor of ethylene, might be expected to interact to promote abscission-related processes. To test this hypothesis, Thompson Seedless grape berries were subjected to applications of MeJA and ACC to determine whether those compounds, applied individually and in combination, affected berry ethylene production, detachment force, preharvest abscission, and the development of dry stem scars. 


\section{IV.4.Material and Methods.}

\section{IV.4.1. Location and vineyard characteristics.}

The experiments were conducted at the University of California Kearney Agricultural Center, Parlier, CA, with own-rooted Vitis vinifera cv. Thompson Seedless grapevines supported by an overhead arbor trellis. The vines, planted in 1995, were quadrilateral cordon trained and cane-pruned, leaving $\sim 6$ canes per vine and 15 nodes per cane. Vines were spaced $\sim 1.83 \mathrm{~m}$ within rows and $3.65 \mathrm{~m}$ between rows, which were oriented east to west. All vines were subjected to cultural practices considered normal and ordinary for dry-on-vine raisin grapes in the San Joaquin Valley (CHRISTENSEN. 2000), except that the canes were not severed and raisins were not made.

\section{IV.4.2. Experiment I.}

In 2010, a preliminary study was conducted. Four vines, each surrounded within and between rows by guard vines, were selected based on their uniformity of appearance and crop load. Nine clusters of similar size and appearance were selected on each vine and randomly assigned to one of nine possible treatment combinations of MeJA: 0, 672, or 1,344 mg/L (Bedoukian Research, Inc., Danbury, CT) and ACC: 0, 500 , or $1,000 \mathrm{mg} / \mathrm{L}$ (Valent BioSciences, Libertyville, IL). Each treatment solution also included 0.05\% Latron-B 1956 spreader-sticker (Loveland Industries, Inc., Greeley, CO). A factorial treatment structure in a randomized complete block design (RCBD) was employed, with individual vines considered blocks and individual clusters considered experimental units, so each treatment combination was applied to a cluster on each vine, and all treatment combinations were replicated on each of the four vines.

On 20 Sep 2010, when berries had accumulated 22 Brix, handheld sprayers were used to apply the solutions directly to the appropriate clusters until run off $(\sim 0.06$ L/cluster), and polyethylene shields were used to prevent overspray from contacting other clusters. After the clusters had dried, they were enclosed in polypropylene mesh bags to catch any berries that might abscise. The bags had a resealable flap at the bottom, from which berries were collected and counted at harvest (GONZÁLEZ-HERRANZ et al., 2009).

On $23 \mathrm{Sep}$, the peduncle of each cluster was severed with shears and the clusters, still enclosed within mesh bags, were carefully transported to a laboratory where FDF measurements were made. The clusters were gently removed from their bags, and small shears were used to sever 10 berries from the top, middle, and bottom 
part of each cluster, retaining the pedicel and a short section of rachis with each berry. Each berry was then placed in a jig attached to a force gauge (DPS-11; Imada, Northbrook, IL), force parallel to the fruit axis was applied to the rachis until it detached from the berry, and peak force was recorded (GONZÁLEZ-HERRANZ et al., 2009).

\section{IV.4.3. Experiment II.}

In 2013, a second trial with more measurement times and response variables was conducted. A factorial treatment structure in a RCBD was again employed. This trial included five plots (replicates), each composed of six adjacent vines in a row. Within each plot, 28 clusters were randomly selected from among all the clusters available on the six vines in each plot, and the clusters were assigned to receive one of four possible combinations of MeJA ( 0 or $1,344 \mathrm{mg} / \mathrm{L}$ ) and ACC (0 or 1,000 mg/LACC), with $0.05 \%$ Latron-B 1956. Seven clusters per plot received the same treatment combination so that a cluster subjected to each treatment could be harvested from each of the five plots on each of seven observation dates: the day of treatment and 1 , $2,3,4,5$, and 10 days after treatment (DAT).

On 25 Aug 2013, when grapes had amassed 21ํㅡㄹ Brix, one cluster per treatment per block was harvested. The remaining clusters were then treated with the appropriate solution and, when dry, were enclosed in mesh bags as in the 2010 experiment. On 1, $2,3,4,5$, and $10 \mathrm{DAT}$, the number of berries that had abscised before harvest from a cluster of each treatment and block was counted to determine the $\%$ abscission. The clusters were then harvested and FDF was measured on 10 berries, as in 2010. After each of the ten berries was detached, the stem-end condition of each detached berry was observed and assigned to one of three classes: wet, dry, or with the pedicel attached. Approximately 100 other berries from the same clusters were also clipped from their clusters, retaining their pedicels, and used to determine ethylene production rate. The berries were weighed and placed in airtight $473 \mathrm{~mL}$ glass mason jars (Kerr Glass Manufacturing, Lancaster, PA), filling the jars by approximately half. The jars were then sealed and held for $1 \mathrm{hr}$ at $20^{\circ} \mathrm{C}$. At that time, a sample of headspace gas was taken with a gas-tight syringe passed through silicone septa installed in the jar lids and injected into a gas chromatograph (series 400 AGC 211-2; EG\&G Chandler, Broken Arrow, OK) equipped with two $8 \% \mathrm{NaCl}$ on alumina F-1 columns $(0.32 \times 122$ $\mathrm{cm}$ and $0.32 \times 30 \mathrm{~cm}, 80 / 100$ mesh $)$ and one molecular sieve $5 \mathrm{~A}$ column $(0.32 \times 91$ $\mathrm{cm}, 80 / 100$ mesh) and a flame ionization detector. Separations were performed at $70^{\circ} \mathrm{C}$ and a flow rate of $60 \mathrm{~mL} / \mathrm{min}$ using a flow gas mixture consisting of hydrogen (220 kPa), compressed air (83 kPa), and helium (248 kPa) and a sample injection 
volume of $2.0 \mathrm{~mL}$. Quantification of ethylene was accomplished by comparing sample and standard peak heights. The measurements were expressed in $\mathrm{nL} / \mathrm{g}$ fresh wt/hr.

\section{IV.4.4 Data analysis.}

All data were subjected to analysis of variance (PROC GLM) by date, using SAS statistical software (SAS Inst., Cary, NC). When appropriate, treatment means were separated by Tukey-Kramer adjusted $t$ test $(p=0.05)$.

\section{IV.5.Results}

In experiment I, MeJA interacted with ACC $(p=0.02)$ to reduce FDF at 3 DAT, the only observation date that year (Table IV.1). Without ACC, MeJA did not reduce FDF, and without MeJA, neither did ACC. The FDF of grapes treated with $\geq 500 \mathrm{mg} / \mathrm{L}$ ACC and $\geq 672 \mathrm{mg} / \mathrm{L}$ MeJA was 25 to $30 \%$ lower than the FDF of grapes treated with MeJA but not ACC. Treatment with a combination of $1,344 \mathrm{mg} / \mathrm{L} \mathrm{MeJA}$ and 500 or $1,000 \mathrm{mg} / \mathrm{L}$ ACC reduced FDF by more than $50 \%$ compared to treatment with 1,344 $\mathrm{mg} / \mathrm{L}$ MeJA alone.

Table IV.1. Effect of 1-aminocyclopropane-1-carboxylate (ACC) and methyl jasmonate (MeJA) on fruit detachment force (FDF) of Thompson

Seedless grapes three days after treatment in 2010.

\begin{tabular}{lccc}
\hline \multicolumn{4}{c}{ Fruit detachment force (N) } \\
\hline & \multicolumn{4}{c}{$\operatorname{MeJA}(\mathrm{mg} / \mathrm{L})$} \\
\cline { 2 - 5 } ACC $(\mathrm{mg} / \mathrm{L})$ & 0 & 672 & 1.344 \\
\hline 0 & 1.176 a A & 0.884 a A & 0.962 a A \\
500 & 1.190 a A & 0.649 ab A & 0.342 b B \\
1,000 & 1.242 a A & 0.623 b A & 0.439 b B \\
\hline
\end{tabular}

Values are treatment means, $n=4$. Within rows, values are significantly different if followed by a different lower case letter. Within columns, values are significantly different if followed by a different upper case letter $(p<0.05)$.

The primary and interaction effects of MeJA and ACC on FDF differed from those on berry abscission. MeJA stimulated grape berry abscission ( $p=0.002)$ but ACC did not $(p=0.07)$, and MeJA and ACC did not interact to affect abscission ( $p=$ 0.38). Grapes did not abscise from clusters unless they were treated with MeJA, and a similar percent berry abscission, 16 to $23 \%$, was noted from clusters treated with 672 or 1,344 mg/L MeJA. In experiment II, MeJA plus ACC markedly and rapidly increased grape berry ethylene production (Figure IV.1). At 1 DAT, grapes treated with both MeJA and ACC produced 19 times more ethylene than untreated fruit, whereas grapes 
treated with ACC singly produced $\sim 5$ times more ethylene than untreated berries. Ethylene production from grapes treated with MeJA, with or without ACC, began to decline 2 DAT, though berries treated with ACC still produced 10 times more ethylene than untreated berries, and berries treated with MeJA and ACC produced nearly 30 times more ethylene than controls. Ethylene production from berries treated with MeJA plus ACC further declined at 3 DAT, though it was still greater than that of any other treatment. By 4 DAT, grapes treated with the combination of MeJA and ACC produced similar amounts of ethylene as grapes treated with ACC only, but grapes subjected to either of those two treatments still produced more ethylene than grapes subjected to other treatments. By 5 and 10 DAT, grapes treated with ACC produced more ethylene than other grapes, though by 10 DAT most of the berries from clusters treated with MeJA and ACC had abscised, either before or immediately after harvest, so there were no longer enough nonabscised grapes to use for ethylene measurements. Grapes treated with ACC only had a different pattern of ethylene evolution production than those treated with MeJA, either singly or in combination with ACC: grapes treated only with ACC had a steady, relatively moderate, elevated production of ethylene throughout the study period.

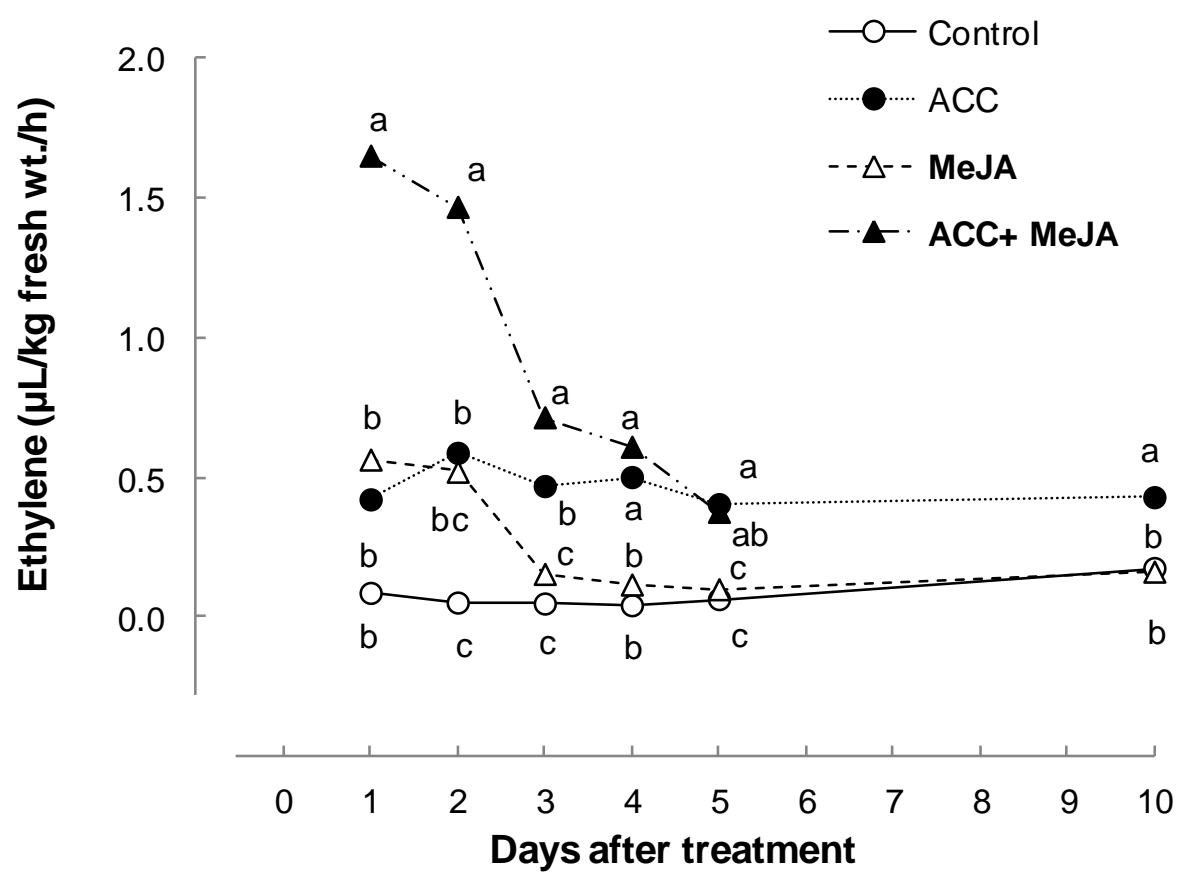

Figure VI.1. Effect of treatments of 1,000 mg/L 1-aminocyclopropane-1-carboxylic (ACC), $1,344 \mathrm{mg} / \mathrm{L}$ methyl jasmonate (MeJA), and their combination on ethylene production by Thompson Seedless grapes on several days after treatment in 2013. Means $(n=5)$ followed by a different letter on each day are significantly different $(p=$ 0.05 ). Due to berry abscission during handling, there were not enough berries with pedicels attached to measure ethylene production at 10 DAT in the ACC + MeJA treatment. 
In 2013, ACC reduced FDF on 1 DAT, and almost every day thereafter; MeJA also reduced FDF, starting at 2 DAT, then every day thereafter (Table IV.2). At 3 and 4 DAT, ACC and MeJA interacted to affect FDF as they did in 2010 (interaction $p=0.02$ ), and the combination of ACC and MeJA reduced FDF to half of that observed in the other treatments.

Table IV.2. Effect of 1-aminocyclopropane-1-carboxylate (ACC) and methyl jasmonate (MeJA) on fruit detachment force of Thompson Seedless grapes at different intervals in 2013.

\begin{tabular}{lccccccc}
\hline & \multicolumn{7}{c}{ Fruit detachment force $(\mathrm{N})$ : days after treatment } \\
\cline { 2 - 8 } & 0 & 1 & 2 & 3 & 4 & 5 & 10 \\
\hline ACC $(\mathrm{mg} / \mathrm{L})$ & & & & & & & \\
$\quad 0$ & 1.716 & 1.254 & 1.093 & 1.143 & 1.139 & 1.105 & 1.099 \\
1,000 & 1.616 & 0.956 & 0.756 & 0.894 & 0.813 & 0.966 & 0.740 \\
MeJA (Mg/L) & & & & & & & \\
$\quad 0$ & 1.566 & 1.225 & 1.078 & 1.224 & 1.215 & 1.373 & 1.147 \\
1,344 & 1.766 & 0.984 & 0.771 & 0.813 & 0.737 & 0.699 & 0.687 \\
Significance & & & & & & & \\
ACC & 0.56 & 0.03 & $<0.01$ & 0.02 & $<0.01$ & 0.15 & $<0.01$ \\
MeJA & 0.26 & 0.07 & $<0.01$ & $<0.01$ & $<0.01$ & $<0.01$ & $<0.01$ \\
ACC x MeJA & 0.30 & 0.96 & 0.10 & 0.05 & $<0.01$ & 0.58 & 0.34 \\
\hline
\end{tabular}

Values are treatment means, $\mathrm{n}=10$.

No berries abscised until 2 DAT, regardless of treatment, so berry abscission data from 1 DAT is not shown. By 2 DAT, berries began to abscise from clusters treated with MeJA, regardless of whether they were also treated with ACC (Table IV.3). At 3, 4, and 10 DAT, ACC and MeJA interacted to promote berry abscission, with the combination of ACC and MeJA inducing much greater abscission than MeJA alone, which in turn stimulated more abscission than ACC alone or untreated clusters.

By 1 DAT, dry stem scars became much more common on berries detached from clusters treated with MeJA than on berries detached from clusters that were not treated with MeJA, regardless of whether those clusters were also treated with ACC (Figure IV.2). However, the combination of ACC and MeJA especially promoted the development of dry stem scars; $>80 \%$ of the berries from clusters treated with both compounds had dry stem scars on most observation dates (Figure IV.2B). The application of ACC alone had little effect on dry stem scar incidence except at 10 DAT, when clusters treated with ACC alone had a similar proportion of berries with a dry stem scar as those treated with MeJA and ACC. 
Table IV.3. Effect of methyl jasmonate (MeJA) and 1-aminocyclopropane-1-carboxylate (ACC) on berry abscission of Thompson Seedless grapes in 2013.

\begin{tabular}{llccccc}
\hline $\begin{array}{l}\text { MeJA } \\
(\mathrm{mg} / \mathrm{L})\end{array}$ & $\begin{array}{l}\mathrm{ACC} \\
(\mathrm{mg} / \mathrm{L})\end{array}$ & \multicolumn{5}{c}{ Abscised berries $(\%)$ days after treatment } \\
\cline { 2 - 7 } & 0 & $0.0 \mathrm{a}^{\mathrm{a}}$ & $0.0 \mathrm{a}$ & $0.0 \mathrm{a}$ & $0.3 \mathrm{a}$ & $0.0 \mathrm{a}$ \\
& 1,000 & $0.0 \mathrm{a}$ & $0.0 \mathrm{a}$ & $0.16 \mathrm{a}$ & $0.1 \mathrm{a}$ & $0.2 \mathrm{a}$ \\
1,344 & 0 & $2.7 \mathrm{a}$ & $0.0 \mathrm{a}$ & $1.8 \mathrm{~b}$ & $16.3 \mathrm{a}$ & $3.6 \mathrm{~b}$ \\
& 1,000 & $5.3 \mathrm{a}$ & $6.9 \mathrm{~b}$ & $21.6 \mathrm{a}$ & $21.3 \mathrm{a}$ & $36.0 \mathrm{a}$ \\
Significance & ACC & 0.49 & 0.03 & 0.03 & 0.57 & $<0.01$ \\
& MEJA & 0.05 & 0.03 & 0.02 & $<0.01$ & $<0.01$ \\
& ACCx MeJA & 0.49 & 0.03 & 0.04 & 0.55 & $<0.01$ \\
\hline
\end{tabular}

${ }^{a}$ Values are treatment means, $n=5$. Within each column and concentration of MeJA, means followed by a different letter are significantly different $(p<0.05)$.
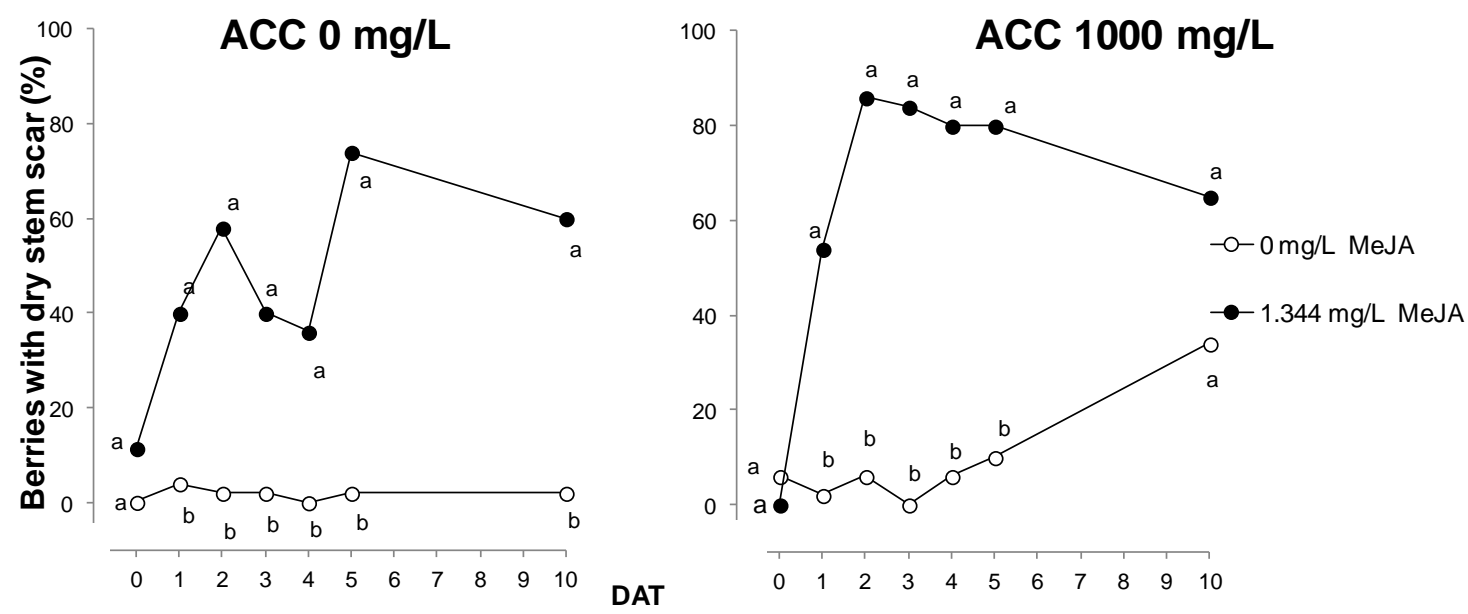

Figure IV.2. Effect of 1-aminocyclopropane-1-carboxylic (ACC) and methyl jasmonate (MeJA) on the percentage of Thompson Seedless grape berries with dry stem scars after detachment on several days after treatment in 2013. (A) The effect of MeJA on grapes with $0 \mathrm{mg} / \mathrm{L} \mathrm{ACC}$, and $(B)$ the effect of MeJA on grapes with $1000 \mathrm{mg} / \mathrm{L} \mathrm{ACC}$. Values are treatment means, $n=5$. Means with a different letter on each day are significantly different $(p=0.05)$.

\section{6.Discussion.}

The results of experiment I suggested a potential benefit in combining MeJA and ACC, a finding that agrees with UZQUIZA et al. (2013a, 2013b), who showed that combinations of MeJA with ethephon, an ethylene-releasing agent, were more effective at reducing FDF of Verdejo and increasing abscission of Sauvignon blanc grapes than single applications of either compound. However, the studies on Verdejo and Sauvignon blanc tested much more concentrated applications of MeJA, up to 8,960 
$\mathrm{mg} / \mathrm{L}$, and observed less loosening and abscission than occured with Thompson Seedless subjected to far lower concentrations of MeJA. For example, the data reported here suggest that 672 to $1,344 \mathrm{mg} / \mathrm{L}$ MeJA combined with 500 to $1,000 \mathrm{mg} / \mathrm{L}$ ACC stimulates considerable abscission of Thompson Seedless grapes. Striking differences among cultivars in responsiveness to abscission agents has been previously reported in grape (FIDELIBUS et al., 2007) and blueberry (MALLADI et al., 2012), though the physiological basis for such differences is unclear.

Treatments had different effects on FDF and abscission, probably because a decline in FDF precedes abscission, but also due to the fact that grapes with very low FDF generally abscise before FDF measurements can be made (GONZÁLEZ-HERRANZ et al., 2009). To confirm the interactive effects of MeJA and ACC on grape berry abscission, to develop a better understanding of the time course of these treatment effects, and to determine how these treatments may affect ethylene production by berries, a variable that is critical in orange fruit abscission (KENDER et al., 2001), a similar study was conducted in 2013, with more observation times and response variables measured.

Experiment II confirmed that MeJA and ACC stimulated ethylene production by the grapes and that ethylene production preceded, or occurred along with, other abscission-related responses, as was observed with MeJA in oranges (HARTMOND et al., 2000; KENDER et al., 2001). Moreover, coapplication of MeJA and ACC stimulated grapes to produce far more ethylene than grapes treated with either compound singly, and the combined treatment was also far more effective at stimulating berry abscission. However, our data suggest that MeJA effects on grape berry abscission might not be solely via ethylene production. For example, in the first 2 DAT, berries treated with MeJA or ACC alone produced similar concentrations of ethylene, but for the remainder of the study, berries treated with MeJA alone produced less ethylene than berries treated with ACC alone, even though the MeJA-treated grapes generally had lower FDF, greater abscission, and a higher proportion of dry stem scars than the grapes treated with ACC.

These data support those of MALLADI et al. (2012), who indirectly showed that the abscission activity of MeJA on blueberries may not depend entirely on ethylene, as the coapplication of MeJA and AVG, an ethylene biosynthesis inhibitor, reduced but did not eliminate MeJA-induced abscission. 


\section{IV.7. Conclussion.}

The FDF and berry abscission data presented may suggest the combination of MeJA and ACC was less effective than it actually was because abscised berries were counted immediately before harvesting the clusters of grapes, but harvest and sample preparation invariably detached many of the most loosely-attached berries before FDF measurements could be made. As previously noted, so many berries abscised from clusters treated with MeJA and ACC due to handling during harvest and sampling of the clusters that there were not enough berries with pedicels attached to measure ethylene production at 10 DAT. Preharvest fruit drop is undesirable, so harvest would need to occur after FDF was reduced, but before considerable abscission begins: within 2 or 3 DAT, as suggested by previous studies (FIDELIBUS and CATHLINE 2010; GONZALEZ-HERRANZ et al., 2009).

\section{IV.8. Literature cited.}

ChRISTENSEN, L.P. 2000. Raisin production manual. University of California, Agricultural and Natural Resources, Oakland.

FAn, X., J.P. MATtheis, and J.K. Fellman. 1998. A role of jasmonates in climacteric fruit ripening. Planta 204:444-449.

Ferrara, G., A. Pacifico, P. Simeone, M. Palasciano, and A. Godini. 2010. Various growth regulators as potential abscission agent for some seedless grape cultivar for fresh-cut products. In Proceedings for the Sixth International Table Grape Symposium, pp. 19-21. University of California Cooperative Extension, Davis.

FideliBuS, M., and K. CATHLine. 2010. Dose and time dependent effects of methyl jasmonate on abscission of grapes. In Proceedings for the Eleventh International Symposium on Plant Regulators in Fruit Production. G. Costa (ed.). Acta Hort. 884:725-728.

FidelibuS, M.W., K.A. CATHLINE, and J.K. BuRNS. 2007. Potential abscission agents for raisin table and wine grapes. HortScience 42:1626-1630.

Gonzalez-Herranz, R., K.A. Cathline, M.W. Fidelibus, and J.K. Burns. 2009. Potential of methyl jasmonate as a harvest aid for Thompson Seedless grapes: Concentration and time needed for consistent berry loosening. HortScience 44:1330-1333. 
HaRtMOND, U., R.C. YuAn, J.K. BuRnS, A. Grant, and W.J. KendeR. 2000. Citrus fruit abscission induced by methyl jasmonate. J. Am. Soc. Hort. Sci. 125:547-552.

Hedberg, P.R., and P.B. GoodwiN. 1980. Factors affecting natural and ethephoninduced grape berry abscission. Am. J. Enol. Vitic. 31:109-113.

HOLM, R.E., and W.C. WILSON. 1977. Ethylene and fruit loosening from combinations of citrus abscission chemicals. J. Am. Soc. Hort. Sci. 102:576-579.

Kender, W.J., U. Hartmond, J.K. Burns, R.C. Yuan, and L. Pozo. 2001. Methyl jasmonate and $\mathrm{CMN}$-pyrazole applied alone and in combination can cause mature orange abscission. Sci. Hortic. 88:107-120.

Kim, J., B. Dotson, C. Rey, J. Lindsey, A.B. Bleecker, B.M. Binder, and S.E. PATTERSON. 2013. New clothes for the jasmonic acid receptor COI1: Delayed abscission, meristem arrest and apical dominance. PLoS ONE 8:e60505.

MALLADI, A., T. VASHISTH, and L.K. JOHNSON. 2012. Ethephon and methyl jasmonate affect fruit detachment in rabbiteye and southern highbush blueberry. HortScience 47:1745-1749.

MUKKUN, L., and Z. SINGH. 2009. Methyl jasmonate plays a role in fruit ripening of Pajaro strawberry through stimulation of ethylene biosynthesis. Sci. Hortic. 123:510.

SANIEWSKI, M., J. NoWACKI, J. CZAPSKI, and E. LANGE. 1987a. The effect of methyl jasmonate on ethylene and 1-amlnocyclopropane-I-carboxylic acid production in apple fruits. Biol. Plantarum 29:199-203.

SANIEWSKI, M., H. URBANEK, and J. CZAPSKI. 1987b. Effects of methyl jasmonate on ethylene production, chlorophyll degradation, and polygalacturonase activity in tomatoes. J. Plant Physiol. 127:177-181.

UzquizA, L., R. GonzÁlez, M.R. GonzÁlez, and P. MARTín. 2013a. Potential of combined ethephon and methyl jasmonate treatments for improving mechanical harvesting of wine grapes. Eur. J. Hortic. Sci. 78:169-175.

Uzquiza, L., R. GonzÁlez, M.R. GonzÁlez, and P. MARTín. 2013b. Aplicaciones de etefón y metil jasmonato para facilitar el desprendimiento del fruto en vides cv. Sauvignon blanc. In Proceedings for the Seventh Congreso lbérico de Agroingeniería y Ciencias Hortícolas, 36 pgs. Sociedad Española de Agroingeniería y Sociedad Española de Ciencias Hortícolas, Madrid. 
V.ENSAYO 3 


\section{ENSAYO 3.}

\section{A preharvest treatment of ethephon and methyl jasmonate affect mechanical harvesting performance and composition of 'Verdejo' grapes and wines.}

(Un tratamiento prevendimia de etefón y metil jasmonatos afecta al rendimiento de la vendimia mecanizada y a la composición de uvas y vino 'Verdejo').

Autores: L.Uzquiza1', R. González¹, M.R. González¹, M.W. Fidelibus², Pedro Martín ${ }^{1}$.

${ }^{1}$ Departamento de Producción Vegetal y Recursos Forestales, Universidad de Valladolid, Av. Madrid 57, C.P/ 34004, Palencia, España.

${ }^{2}$ Department of Viticulture and Enology, University of California, Davis, CA 95616.

Publicado en: European Journal of Horticultural Science,80 (3). In press. Año 2015.

\section{V.1.Resumen.}

En estudios anteriores hemos mostrado que la aplicación combinada de etefón y metil jasmonato en vid (Vitis vinifera L.) puede reducir la fuerza de desprendimiento del fruto y promover la formación de una capa de abscisión entre el pedicelo y la baya, sin causar pérdidas de cosecha previas a la vendimia o defoliación (UZQUIZA et al. 2013). En teoría, estos efectos podrían ayudar a minimizar el daño físico a las uvas y el volumen de mosto liberado durante la vendimia mecanizada, lo que podría reducir la incidencia de procesos oxidativos no deseados antes de que el producto llegue a la bodega. El objetivo de este trabajo fue estudiar los efectos de este tratamiento en el rendimiento de la vendimia mecanizada, y en la calidad del mosto y del vino. Los experimentos se llevaron a cabo en 2011 y 2013, en un viñedo cv. Verdejo localizado en la Denominación de Origen Rueda (centro-norte de España). En un diseño factorial completamente aleatorizado se compararon diferentes tratamientos, combinando la aplicación de agentes de abscisión (etefón $1000 \mathrm{mg} \cdot \mathrm{L}^{-1}$ más metil jasmonato 8960 $\mathrm{mg} \cdot \mathrm{L}^{-1}$ pulverizado sobre los racimos 10 días antes de la vendimia, frente a controles 
sin tratar), y el método de vendimia (vendimia manual frente mecanizada con diferentes frecuencias de los sacudidores, 400 y 425 golpes $\cdot \mathrm{min}^{-1}$ ). Los tratamientos prevendimia no afectaron significativamente a las pérdidas de producto durante la vendimia a 400 golpes $\cdot \mathrm{min}^{-1}$ pero, a 425 golpes $\cdot \mathrm{min}^{-1}$, las pérdidas totales en las viñas tratadas fueron un $4.2 \%$ mayores que en las no tratadas. El porcentaje de mosto libre en la pasta vendimiada fue menor en las plantas tratadas (20.6\%) que en los controles $(23.2 \%)$ cuando la frecuencia de sacudido fue mayor. Los agentes de agentes de abscisión tendieron a reducir el contenido en potasio del mosto e incrementaron los contenidos en ácidos hidroxicinámicos y polifenoles totales, pero no afectaron a la intensidad colorante ni a la estabilidad oxidativa de los vinos.

Palabras clave: abscisión, oxidación, reguladores del crecimiento, polifenoles, Vitis vinifera $\mathrm{L}$.

\section{V.2. Summary.}

Previously we showed that the combined application of ethephon and methyl jasmonate to grapes (Vitis vinifera L.) may decrease fruit detachment force and promote the formation of an abscission layer between the pedicels and berries, without causing preharvest yield losses or defoliation (UZQUIZA et al. 2013). Theoretically, such effects could help minimize the physical damage to berries and the volume of must released during mechanical harvesting which could, in turn, reduce the opportunity for undesirable oxidative processes to occur before the product comes into the winery. The aim of this work was to study the effects of this treatment on mechanical harvesting performance, and on must and wine quality. The experiments were conducted in 2011 and 2013, in a 'Verdejo' vineyard located in 'Rueda' Appellation d'Origine area (North-Central Spain). In a completely randomized factorial design different treatments were compared, combining the application of abscission agents (ethephon $1000 \mathrm{mg} \cdot \mathrm{L}^{-1}$ plus methyl jasmonate $8960 \mathrm{mg} \cdot \mathrm{L}^{-1}$ sprayed on the clusters 10 days before harvesting, versus untreated controls), and type of harvest (manual picking and mechanical at different shaking frequencies, 400 and 425 shakes. $\min ^{-1}$ ). The preharvest treatment did not significantly affect product losses during mechanical harvesting at 400 shakes $\cdot \mathrm{min}^{-1}$ but, at 425 shakes $\cdot \mathrm{min}^{-1}$, total losses in treated vines were $4.2 \%$ higher than in untreated. The percentage of free must in the harvested mass was lower in treated vines $(20.6 \%)$ than in controls $(23.2 \%)$ when shaking frequency was higher. The abscission agents tended to reduce potassium content in 
the must and increased hydroxycinnamic acid and total polyphenol contents, but they did not affect colour intensity or oxidative stability of wines.

Key words: abscission, oxidation, plant growth regulators, polyphenol, Vitis vinifera L.

\section{V.3.Introduction.}

Compared to manual picking, mechanical harvesting reduces vineyard operating costs and may better enable harvesting at optimal levels of grape maturity since mechanical harvest is less dependent on labor availability and can proceed more quickly. However, mechanical harvest, unlike manual picking, generally detaches individual broken berries which release free must, and therefore promotes oxidative browning and uncontrolled fermentation processes that may begin before the fruit arrives at the winery (MEYER, 1969).

Polyphenols (anthocyanins and tannins) are responsible for the colour and astringency of wines (RIBÉREAU-GAYON and GLORIES, 1987). The oxidation of phenolic compounds in grapes and musts induces the formation of different polymers that may impart a brown colour to wines, reduce their stability, and modify their organoleptic characteristics (NAGEL and GRABER 1988; ALLEN et al. 2011). Hydroxycinnamates are the major class of phenolics and therefore, the major oxidation substrates and browning precursors in white wines (SINGLETON et al. 1984). When grapes are crushed, polyphenol oxidase enzymes rapidly oxidize the hydroxycinnamates in the released must to quinones (ROBARDS et al. 1999). By contrast, the wine oxidation is mainly a non enzymatic process, in which oxygen does not directly react with phenolic compounds (OLIVEIRA et al. 2011).

Numerous studies have shown that methyl jasmonate or ethylene releasing compounds such as ethephon (2-chloroethyl phosphonic acid), sprayed on clusters at the beginning of ripening, increase the phenolic content and the colour intensity of musts and wines (GALLEGOS et al. 2006; RuIz-GARcíA et al. 2012). Applied a few days before the harvest, both plant growth regulators may stimulate grape berry abscission, thus reducing the force needed to detach the berries and also promoting the development of a dry stem scar at the abscission zone between the pedicels and berries (FIDELIBUS et al. 2007; GONZÁLEZ-HERRANZ et al. 2009; UZQUIZA et al. 2013, 2014a, 2014b). These effects could allow harvester machines to work at lower shaker frequency and, therefore, reducing damage to the berries and minimize the release of free must. In this way, they would help to improve wine quality in mechanically harvested vineyards. 
Additive or synergistic effects between abscission agents could be exploited in combined treatments to facilitate mechanical harvesting, reducing the amount of products needed and avoiding excessive residues in fruits. In previous studies (UZQUIZA et al. 2013), we have demonstrated that combined applications of ethephon (1000 mg $\cdot \mathrm{L}^{-1}$ ) and methyl jasmonate $\left(8960 \mathrm{mg} \cdot \mathrm{L}^{-1}\right) 8$ days before harvest have an additive effect on promoting fruit abscission-related processesin grapes cv. Verdejo, without causing preharvest yield losses or defoliation. However, the effect of these treatments on must and wine quality has not yet been determined. Therefore, the aim of this work was to study the effects of the application of ethephon plus methyl jasmonate on mechanical harvesting performance of 'Verdejo' grapes, and on must and wine composition.

\section{V.4.Material and methods.}

The study was carried out in a 'Verdejo'/110 Richter vineyard located in "Rueda "Appellation d'Origine area (North-Central Spain). 'Verdejo' is a white grape cultivar, native from Rueda, which produces famous aromatic wines. The vineyard was planted

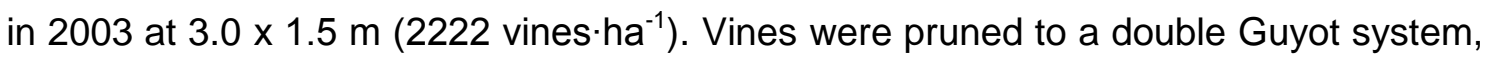
leaving twenty buds per plant, and were grown in trellis under irrigation, according to the standard practice in the zone. The soil is a deep sand, with basic $\mathrm{pH}(8.2)$ and medium organic matter content (1.8\%).

In a trial carried out in 2011 and 2013, fully crossed factorial experiments were conducted. The factors included (i) application of abscission agents (ethephon 1000 $\mathrm{mg} \cdot \mathrm{L}^{-1}$ plus methyl jasmonate $8960 \mathrm{mg} \cdot \mathrm{L}^{-1}$ versus untreated controls), and (ii) type of harvest (manual picking and mechanical at different shaking frequencies as described below). Experimental design was completely randomized with three replications, including 10 adjacent vines per replication for mechanical harvest and 5 vines for the manual one. Each base plot was isolated from the rest by two vines to prevent overspray from contacting close plants. Two additional plants were included at the beginning of mechanically harvested treatments, to clean the machine after the adjacent treatment has been harvested.

Abscission agent solutions were prepared with Ethrel 48 (ethephon $48 \% \mathrm{w} / \mathrm{v}$, Nufarm España, SA) and methyl jasmonate (95\% purify, Sigma-Aldrich), and included PG Supermojante $0.1 \% \mathrm{v} / \mathrm{v}$ (alquiphenolethoxilated/propoxilated $99.6 \% \mathrm{w} / \mathrm{w}$; Dow AgroSicences Iberica, SA) as wetting agent. Treatments were applied to the fruiting zone of the vines with a hand sprayer (average around $450 \mathrm{~L} \cdot \mathrm{ha}^{-1}$ ) when grapes had 
amassed sufficient soluble solids: 2 Sept 2011 (23.0 ํㅏix) and 23 Sept 2013 (20.5 $\stackrel{\circ}{\circ}$ rix).

Experimental treatments were harvested 10 days after spraying: 12 Sept. 2011 and 2 Oct. 2013. On these dates, 3 clusters per treatment and replication were taken carefully to measure the force required to detach each berry from the rachis. Sample clusters were cut in three portions: top, middle and bottom part, and from each one, two berries were cut with pedicel to measure fruit detachment force (FDF). Each berry was placed in a jig attached to a force gauge (DS2-N5; Imada, IL) and force parallel to the fruit axis was applied to the rachis until it detached from the berry, at which time peak force was recorded. The weight percentage of berries with dry scar tissue in the abscission zone was checked at harvest in another two clusters per treatment and replication.

Mechanical harvesting was carried out using a Gregoire G8.260 (Gregoire Group, France) grape harvester. This $125 \mathrm{~kW}$ powered machine is characterized by fourteen horizontal bow beaters with colleting buckets as a transport system. It presents a pendulum suspension which could follow perfectly the vines limiting damage to the wood. The destemming system was not used. Mechanical harvester speed and shaker frequency were set at $4 \mathrm{~km} \cdot \mathrm{h}^{-1}$ and 400 shakes $\cdot \mathrm{min}^{-1}$ respectively in 2011 . In 2013, an additional experimental treatment with the same speed and 425 shakes $\cdot \mathrm{min}^{-1}$ were included in the trial. For this, all treatments and repetitions were randomly distributed again to maintain the experimental design of the previous year. After mechanical harvesting, $120 \mathrm{mg} \cdot \mathrm{kg}^{-1}$ of potassium metabisulfite were added to the product.

The total amount of picked grapes and the product losses for mechanical harvesting were monitored. Product losses were represented by the grapes left on the vines (unpicked bunches) and the grapes falling ahead of the harvester (on ground losses), and were expressed as a percentage of overall production (harvested fruit + losses). Ground losses were collected in plastic sheets placed on both sides of the vines, while unpicked bunches were collected by hand after the machine had passed. In 2011, abscised berries between the application of the treatments and harvest day also were collected (preharvest losses). In the mechanically harvested product, the amount of released must was determined by draining the mass harvested until runoff ceased, using a $2 \mathrm{~mm}$ mesh. Then, liquid and solid parts were weighted to calculate percentage of must released. 
A standard wine-making process was used to produce the wine from $10 \mathrm{~kg}$ of the harvest of each experimental treatment. Hand-picked clusters were destemmed, and then all treatments were pressed using a pneumatic press (maximum pressure $=2$ bar). For each mechanical harvesting treatment, the quantity of liquid (must) and solid part in the harvested mass were calculated, so proportional amounts were taken to press $10 \mathrm{~kg}$. In all musts obtained, both manual and mechanical treatments, potassium metabisulfite was added to set free sulfur at $30 \mathrm{mg} \cdot \mathrm{L}^{-1}$. Approximately, $4 \mathrm{~L}$ of must for each experimental treatment were held for 24 hours at $5^{\circ} \mathrm{C}$, and then racked for vinification. Alcoholic fermentation was induced by yeast; Saccharomyces cereviseae Zymaflore X16 in 2011, and Saccharomyces cereviseae Zymaflore Spark (Laffort, Laguardia, Spain) in 2013. Then, must in glass jars were kept in a refrigerated cell at $17^{\circ} \mathrm{C}$ to improve yeast growth. Alcoholic fermentation showed a regular trend, and was considered finished with a value of reduced sugar lower than $4 \mathrm{~g} \mathrm{~L}^{-1}$. Free sulfur was set at $30 \mathrm{mg} \mathrm{L}^{-1}$ with potassium metabisulfite, and wines were clarified and decanted at $4^{\circ} \mathrm{C}$ during 48 hours. Then wines were 30 days at $1^{\circ} \mathrm{C}$ for tartaric stabilization in fully filled jars of $2 \mathrm{~L}$ volume, without "air space" to avoid oxidations. Before bottling, free sulfur was set at $30 \mathrm{mg} \mathrm{L}^{-1}$.

Total soluble solids content in the musts, and total acidity, $\mathrm{pH}$, and potassium content in the musts and wines, were determined according to the official methods of analysis established by the European Union (Commission regulation (EEC) No 2676/90, 1990). Absorbances at (total polyphenol index), 320 (estimation of hydroxycinnamic acids content) and $420 \mathrm{~nm}$ (colour intensity) also were measured using a UV/VIS spectrophotometer Jasco V-530. The oxidative stability of the wines was evaluated registering the absorbances at $420 \mathrm{~nm}$ before and after a forced oxidation in a stove, at $50^{\circ} \mathrm{C}$ for $48 \mathrm{~h}$ (ARFELLI et al. 2010).

Data were subjected to factorial analysis of variance (ANOVA) using SAS statistical software (SAS Inst., Cary, NC). The separation of means was accomplished using the Student's test (comparison between two means) and the Least Significant Difference test (LSD, for multiple comparison).

\section{V.5.Results and discussion.}

\section{V.5.1.Berry abscission.}

Confirming earlier observations with 'Verdejo' grapes (UZQUIZA et al. 2013), the preharvest application of ethephon and methyl jasmonate significantly reduced fruit 
detachment force (FDF) with respect to controls (2.02 versus $3.00 \mathrm{~N}$ in $2011 ; 2.59$ versus $3.22 \mathrm{~N}$ in 2013, p<0.05). Others (FIDELIBUS et al. 2007; GonZALEZ-HERRANZ et al. 2009; UZQUIZA et al. 2014b) observed a similar, but more striking effect of methyl jasmonate treatments on FDF of 'Thompson seedless', with lower doses than used here. Thus, there seems to be striking differences among grape cultivars in responsiveness to abscission agents, as MALLADI et al. (2012) also observed for blueberry (Vaccinium sp.).

The lower FDF of treated grapes did not significantly affect preharvest yield losses measured in 2011. The mean value of preharvest fruit drop in 'Verdejo' was $1.4 \%$, lower than the $3 \%$ observed in $\mathrm{cv}$. Sauvignon blanc in a similar experiment (UZQUIZA et al. 2014), and much lower than the $20 \%$ observed on 'Thompson Seedless' vines treated with methyl jasmonate alone (FIDELIBUS and CATHLINE, 2010).

Besides the decrease in FDF, promotion of dry stem scars is another potentially desirable effect of abscission agents. In 2011, approximately $63 \%$ (w/w) more of berries from treated vines developed a dry stem scar in the abscission zone compared to untreated controls $(p<0.01)$. In 2013 , about $24 \%$ more berries from treated vines had dry stem scars than berries from control vines. Dry scars could help minimize entry points for microorganisms (BALLINGER and NESBITT 1982; KOU et al. 2007) and reduce juice leakage from berries during mechanical harvesting and transporting to the winery.

\section{V.5.2.Mechanical harvesting.}

Yield was not significantly affected by the abscission agent treatment (averaged values were $2.54 \mathrm{~kg} \cdot \mathrm{vine}^{-1}$ in 2011 and $4.64 \mathrm{~kg} \cdot \mathrm{vine}^{-1}$ in 2013). Moreover, the treatments did not affect unpicked bunch losses nor ground losses (detached fruits that were not harvested) during mechanical harvesting at 400 shakes. $\min ^{-1}$ in 2011 and 2013 (Fig. V.1). However, at 425 shakes $\cdot \mathrm{min}^{-1}$, treated vines had approximately $4 \%$ higher ground and total losses than untreated vines $(p<0.05)$. Both unpicked bunches and total losses were greater at 400 than at 425 shakes $\cdot \mathrm{min}^{-1}$ regardless of preharvest treatment (Fig. V.1), but ground losses were similar at different shaking frequencies in 2013, agreeing with PeZZI and CAPRARA(2009) and ARFELLI et al. (2010). Other possible losses of product during harvesting process, such as dispersed must on the leaves or in the harvester system, were not measured, but other studies suggest that they represent a low percentage in the total product losses and did not vary at different shaking frequencies (ARFELLI et al. 2010). 


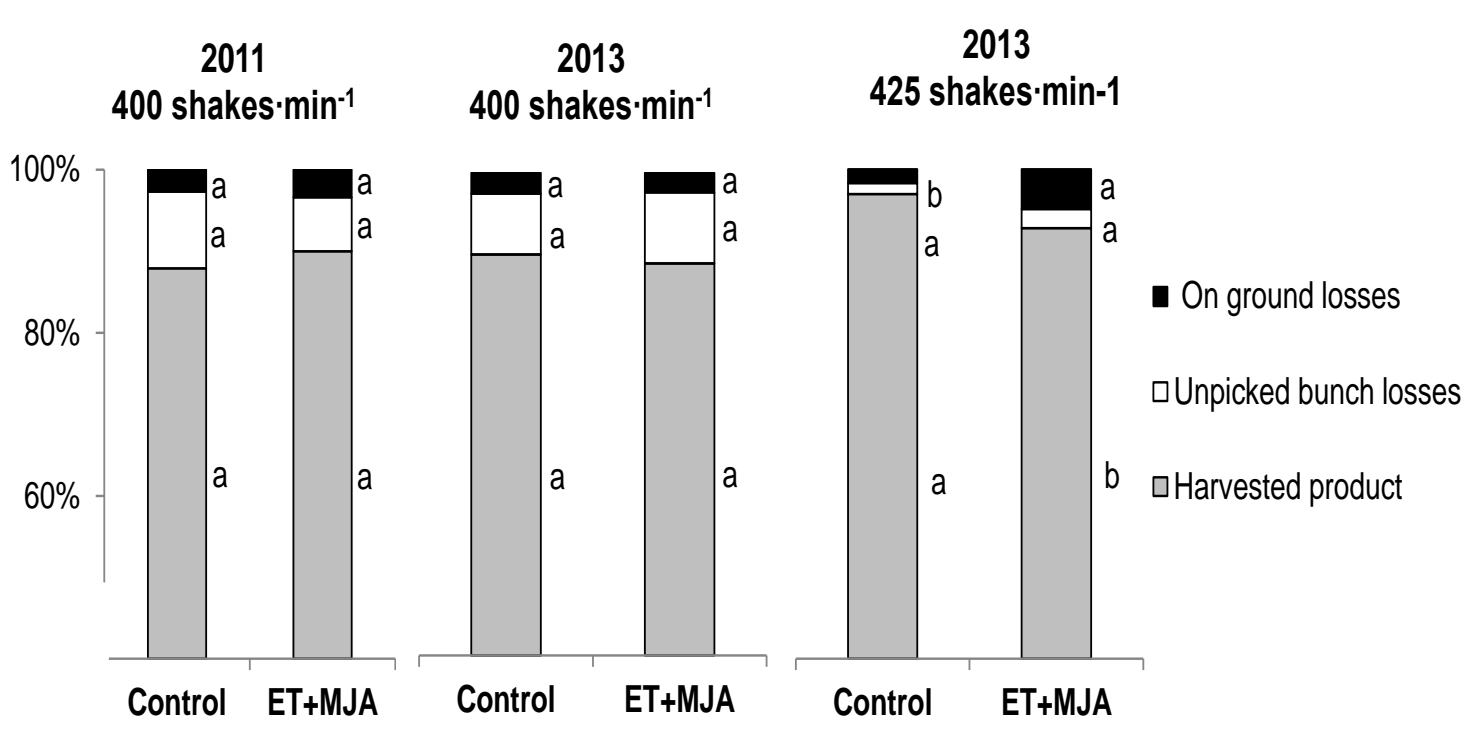

Figure V.1. Influence of the preharvest treatment with ethephon plus methyl jasmonate $(E T+M J A)$ and shaking frequencies on weight percentage of product losses registered during mechanical harvesting in 2011 and 2013. Within a year and shaking frequency, values followed by a different letter are significantly different $(p<0.05)$.

There was less free must $(p<0.05)$ in the harvested mass from vines treated with abscission agents $(20.6 \%)$ than there was from control vines $(23.2 \%)$, when the harvester frequency was 425 shakes $\cdot \mathrm{min}^{-1}$, possibly due to the fact that lower FDF and the increased presence of scar tissue in the abscission zone reduced mechanical damage during harvest. Working at 400 shakes $\mathrm{min}^{-1}$ the same tendency was observed, both in 2011 and 2013, but differences were not statistically significant (data not shown). Shaking frequencies alone did not affect the quantity of must released in 2013 ( $F=0.35, p>0.05)$, in agreement with ARFELLI et al. (2010) and CAPRARA and PeZZI (2011). In contrast, PeZZI and CAPRARA (2009) and CATANIA et al. (2009) observed that must percentages decreased when shaking frequencies were lower.

\section{V.5.3.Must composition}

Must and wine composition were strongly affected by the year, probably due to interannual meteorological differences during grape ripening (Table V.1). Except for total soluble solids content, must composition variables were little affected by harvest method. As Table V.2 shows, the abscission agents applied did not affect total soluble solids content or $\mathrm{pH}$, whereas their impact on total acidity and potassium content depended on the year. 
Table V.1. F values of the factorial analysis of variance of grape and wine composition data, obtained with different preharvest treatment (TR: application of ethephon plus methyl jasmonate versus control) and harvest method (HM: hand picking versus mechanical) in 2011 and 2013. $A_{x}$ : absorbance at $x \mathrm{~nm}$.

\begin{tabular}{|c|c|c|c|c|c|c|c|c|c|}
\hline \multirow{2}{*}{ Parameters } & \multicolumn{9}{|c|}{ Source of variation } \\
\hline & \multicolumn{2}{|l|}{ Model } & \multicolumn{2}{|l|}{ Year } & \multicolumn{2}{|l|}{ TR } & \multicolumn{2}{|l|}{$\mathrm{HM}$} & $\mathrm{TR}^{*} \mathrm{HM}$ \\
\hline \multicolumn{10}{|l|}{ Must } \\
\hline Brix & 11.70 & ** & 22.35 & $* *$ & 3.66 & & 11.09 & ** & $5.42 *$ \\
\hline $\mathrm{pH}$ & 63.43 & ** & 323.22 & $* *$ & 2.54 & & 2.52 & & 3.26 \\
\hline Total acidity & 0.99 & & 0.01 & & 4.11 & * & 0.35 & & 0.31 \\
\hline Potassium content & 28.51 & ** & 119.61 & $* *$ & 5.91 & * & 1.39 & & 0.01 \\
\hline$A_{280}^{(1)}$ & 2.03 & & $\cdot$ & & 8.98 & * & 0.55 & & 0.03 \\
\hline$A_{320}$ & 12.85 & ** & 32.46 & $* *$ & 15.40 & ** & 3.23 & * & 0.47 \\
\hline$A_{420}$ & 17.19 & $* *$ & 70.54 & $* *$ & 0.00 & & 1.86 & & 0.90 \\
\hline $\mathrm{A}_{420} / \mathrm{A}_{320}$ & 9.41 & ** & 37.25 & $* *$ & 0.97 & & 0.72 & & 0.80 \\
\hline \multicolumn{10}{|l|}{ Wine } \\
\hline $\mathrm{pH}$ & 17.51 & ** & 94.69 & $* *$ & 0.21 & & 1.03 & & 0.69 \\
\hline Total acidity & 9.03 & ** & 46.08 & $* *$ & 0.00 & & 2.60 & & 0.80 \\
\hline Potassium content & 27.51 & $* *$ & 142.82 & $* *$ & 0.49 & & 0.72 & & 1.83 \\
\hline$A_{280}$ & 11.05 & ** & 44.54 & $* *$ & 13.21 & ** & 0.77 & & 0.06 \\
\hline $\mathrm{A}_{320}{ }^{(1)}$ & 3.40 & * & . & & 10.18 & ** & 1.92 & & 1.49 \\
\hline$A_{420}$ & 105.21 & $* *$ & 543.11 & $* *$ & 2.01 & & 2.11 & & 3.13 \\
\hline $\mathrm{A}_{420 \mathrm{ox}}{ }^{(2)}$ & 1.32 & & 0.65 & & 3.20 & & 0.06 & & 0.88 \\
\hline
\end{tabular}

The interaction between sources of variation in ANOVA of total soluble solids of must (Table 1) revealed that hand-picked grapes had higher soluble solids than mechanically harvested grapes in the absence of abscission agents (Fig V.2). However, hand-picked and machine harvested grapes had similar soluble solids when abscission agents were applied (Fig.V. 2). Treated grapes tended to have higher levels of total acidity and lower levels of potassium than non-treated grapes, though differences were only significant in 2011 (Table V.2). Reduced potassium content could be considered a positive effect in mechanical harvesting, where skin maceration occurring during the harvest process and transport can increase the inorganic cation content (OUGH, 1969; GUERZONI et al. 1981; ARFELLI et al. 2010). 


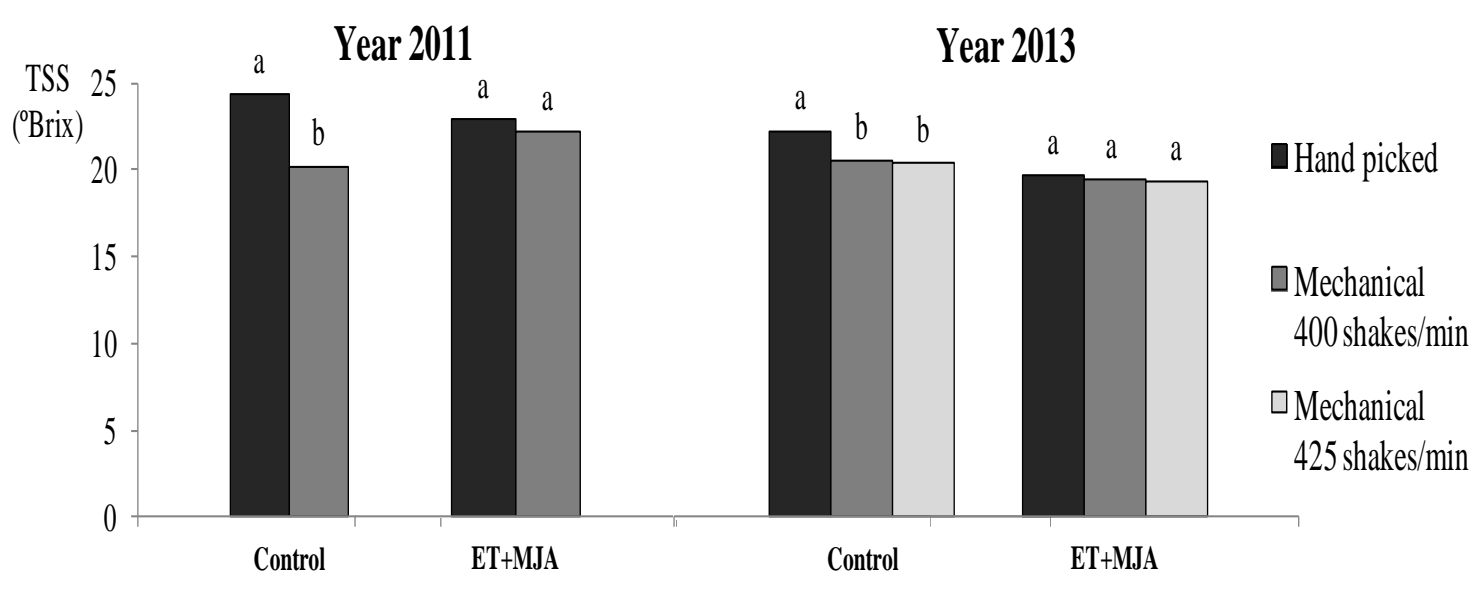

Figure V.2. Effects of the preharvest application with ethephon plus methyl jasmonate and type of harvest on total soluble solid content of the must (TSS). Within treatments, harvest methods with different letter are significantly different $(p<0.05)$.

Table V.2. Effect of preharvest treatment with ethephon plus methyl jasmonate on must and wine composition. $A_{x}$ : absorbance at $\mathrm{x} n$ m.

\begin{tabular}{|c|c|c|c|c|c|c|}
\hline \multirow[b]{2}{*}{ Parameters } & \multicolumn{4}{|c|}{ Year 2011} & \multicolumn{2}{|c|}{ Year 2013} \\
\hline & & Control & & Treatment & Control & Treatment \\
\hline \multicolumn{7}{|l|}{ Must } \\
\hline Brix & 22.28 & \pm 2.50 & $a$ & $22.77 \pm 0.59 \mathrm{a}$ & $21.22 \pm 0.95 a$ & $19.82 \pm 0.48$ \\
\hline $\mathrm{pH}$ & 3.25 & \pm 0.05 & a & $3.26 \pm 0.04 a$ & $3.04 \pm 0.03 a$ & $3.01 \pm 0.02$ \\
\hline Total acidity $\left(\mathrm{g} \cdot \mathrm{L}^{-1}\right)$ & 4.10 & \pm 0.25 & b & $4.61 \pm 0.33 a$ & $4.29 \pm 0.33 a$ & $4.36 \pm 0.22$ \\
\hline Potassium $\left(\mathrm{mg} \cdot \mathrm{L}^{-1}\right)$ & 638 & \pm 78 & a & $512 \pm 77.0 \mathrm{~b}$ & $235 \pm 64.0$ & $200 \pm 41.0$ \\
\hline $\mathrm{A}_{280}$ & - & 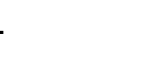 & & - & $13.11 \pm 0.84 b$ & $14.89 \pm 1.38$ \\
\hline $\mathrm{A}_{320}$ & 10.09 & \pm 0.81 & $\mathrm{~b}$ & $10.93 \pm 0.51 a$ & $8.22 \pm 0.43 b$ & $9.37 \pm 0.90$ \\
\hline $\mathrm{A}_{420}$ & 2.24 & \pm 0.31 & a & $1.86 \pm 0.19 b$ & $0.93 \pm 0.18 b$ & $1.15 \pm 0.27$ \\
\hline $\mathrm{A}_{420} / \mathrm{A}_{320}$ & 0.22 & \pm 0.02 & a & $0.17 \pm 0.02 b$ & $0.11 \pm 0.02 a$ & $0.12 \pm 0.03$ \\
\hline
\end{tabular}

\section{Wine}

$\mathrm{pH}$

$3.12 \pm 0.05$ a $3.11 \pm 0.03$ a $2.96 \pm 0.04$ a $2.95 \pm 0.04$ a

Total acidity $\left(\mathrm{g} \cdot \mathrm{L}^{-1}\right) \quad 5.89 \pm 0.34$ a $5.79 \pm 0.27$ a $6.57 \pm 0.27$ a $6.58 \pm 0.34$ a

$\mathrm{A}_{280} \quad 7.23 \pm 0.62$ b $8.22 \pm 0.82$ a $9.28 \pm 0.75$ b $10.44 \pm 0.87$ a

$\mathrm{A}_{420} \quad 0.05 \pm 0.01$ a $0.05 \pm 0.01$ a $0.27 \pm 0.02$ a $0.29 \pm 0.04$ a

$\mathrm{A}_{420 \mathrm{ox}}{ }^{(1)} \quad 0.26 \pm 0.02$ a $0.33 \pm 0.08$ a $0.30 \pm 0.02$ a $0.32 \pm 0.03$ a

${ }^{(1)}$ Value registered after browning test (Arfelli et al. 2010). Within a year, means followed by different letters are significantly different $(p<0.05$, Student's test). 
Regardless of the type of harvest (Table V.2), musts from grapes treated with abscission agents had a higher total polyphenol index (280 $\mathrm{nm}$ absorbance) than controls. In treatments 10 days before harvesting, grapes might rapidly increase ethylene production (UZQUIZA et al. 2014b), and accordingly phenolic content, just as they do following applications of ethephon (GALLEGOS et al. 2006) or MeJA (RUIZGARCíA et al. 2012) around veraison. Despite having different polyphenol indexes, there were no significant treatment effects on colour intensity of must (Table V.1).

Compared to controls, the application of abscission agents increased the 320 $\mathrm{nm}$ absorbance of must (Table V.2), an estimate of the content of hydroxycinnamic acids such as caftaric acid and S-glutathionylcaftaric, which are quickly transformed in benzoquinones by polyphenol oxidase enzymes released when the berries are broken (OLIVEIRA et al. 2011; ALLEN et al. 2011). Musts from hand-picked grapes registered similar values as musts from mechanically harvested fruit in 2011 (around 10.50) but higher values in 2013 (9.42 versus 8.48, p<0.05). The ratio of absorbances at $420 \mathrm{~nm}$ (browning) and at $320 \mathrm{~nm}$ (non oxidized substrate) reflected less enzymatic oxidation of musts from treated grapes than controls in 2011, without significant differences in 2013 (Table V.2).

\section{V.5.4.Wine composition}

Neither field treatments nor harvest method affected total acidity, $\mathrm{pH}$ or potassium content of wines (Table V.1). Accordingly with the results obtained for must composition analysis, the values of absorbance at $280 \mathrm{~nm}$ were higher in wines from treated grapes than controls, regardless of harvest type (Table V.2), while the values at $420 \mathrm{~nm}$ were similar in all experimental treatments (Table V.1). These results disagree with those of NOBLE et al. (1975) and ARFELLI et al. (2010) who have found higher total polyphenol contents and more colour intensity in mechanical than manual harvested grapes. DARÍAS-MARTín et al. (2000) also found differences in 280 and $320 \mathrm{~nm}$ absorbances of wines as function of harvest type, demonstrating a greater extraction of flavonoid and non-flavonoid compounds in maceration that occurs during harvest. In this line, CATANIA et al. (2009) found significant effects of different shaking frequencies on the yellow hue in wines from mechanically harvested fruit.

The final colour intensity of wines after forced oxidation in stove were independent from preharvest treatment or harvest methods, with mean values of 420 $\mathrm{nm}$ absorbances around 0.3 (Tables V.1 and V.2). These results disagree with those of 
ARFELLI et al. (2010), who observed that wines from manually harvested fruit were less sensitive to oxidation than wines from mechanically harvested grapes.

In this work we have shown, for the first time, the effects of preharvest treatments with abscission agents on mechanical grape harvesting and wine composition. Our results show that treatment with ethephon plus methyl jasmonate might slightly reduce yield due to greater on ground losses, especially at high shaking frequencies. However, the abscission agents may improve must quality, by raising hydroxycinnamic acids or decreasing potassium content, though they did not affect colour intensity and oxidative stability of wines.

\section{V.6.References}

Allen, T., M. Herbst-Johnstone, M. Girault, P. Butler, G. Logan, S. Jouanneau, L. NICOLAU and P. KILMARTIN 2011: Influence of grape-harvesting steps on varietal thiol aromas in Sauvignon blanc wines. J. Agric. Food Chem. 59, 10641-10650.

Arfelli, G., E. Sartini, F. Bordini, C. Caprara and F. PezZi 2010: Mechanical harvesting optimization and postharvest treatments to improve wine quality. J. Int. Sci. Vigne Vin 44, 101-115.

BALlingeR, W.E. and W.B. NeSBITT 1982: Postharvest decay of muscadine grapes ('Carlos') in relation to storage temperature, time and stem condition. Am. J. Enol. Vitic. 33, 173-175.

CAprara, C. and F. PeZZI 2011: Measuring the stresses transmitted during mechanical grape harvesting. Biosyst. Eng. 110, 97-105.

Catania, P., M. Vallone and F. Pipitone 2009: Analysis of the main factors influencing the quality of wine from mechanically harvested grapes. J. Ag. Eng.- Riv. di Ing. Agr. 4, 27-30.

DARIAS-MARTín, J.J., O. RODRíGUEZ, E. DíAZ and R.M. LAMUELA-RAVENTÓs 2000: Effect of skin contact on the antioxidant phenolics in white wine. Food Chem. 71, 483487.

FideliBus, M.W., K.A. CATHLine and J.K. BuRns 2007: Potential abscission agents for raisin table and wine grapes. HortScience 42, 1626-1630.

FideliBuS, M.W. and K.A. CATHLINE 2010: Dose and time dependant effects of methyl jasmonate on abscission of grapes. Acta Hort. 884, 725-728. 
Gallegos J.I., R. GonzÁlez, M.R. GonzÁlez and P. Martín 2006: Changes in composition and colour development of 'Tempranillo' grapes during ripening induced by ethephon treatments at veraison. Acta Hort. 727, 505-512.

Gonzalez-HerRanz R., K.A. Cathline, M.W Fidelibus and J.K. BuRns 2009: Potential of methyl jasmonate as a harvest aid for 'Thompson Seedless' grapes: Concentration and time needed for consistent berry loosening. HortScience 44, 1330-1333.

GuERZONI M.E., R. ZIRONI, C. INTRIERI and E. MAGNANINI 1981: Stabilization of white wine by early hyperoxidation of must. Food Technol. Aust. 33, 444-446.

KOU, L., Y. LUO, D. WU and X. LIU 2007: Effects on mild heat treatment on microbiological growth and product quality of packaged fresh cut table grapes. J. Food Sci. 72, 567-573.

MALLADI, A., T. VASHISTH and L.K. JOHNSON 2012: Ethephon and methyl jasmonate affect fruit detachment in rabbiteye and southern highbush blueberry. HortScience 47, 1745-1749.

MEYER, J. 1969: Effect of fruit cane severance of grapevines on must and wine yield and composition. Am. J. Enol. Vitic. 20, 108-117.

NAGEL, C.W. and W.R. GRABER 1988: Effect of must oxidation on quality of white wines. Am. J. Enol. Vitic. 39, 1-4.

Noble, A.C., C.S. OUgh and A.N. Kasimatis 1975: Effects of leaf content and mechanical harvest on wine "quality". Am. J. Enol. Vitic. 26, 158-163.

Oliveira, C.M., A.C.S. Ferreira, V. De Freitas and A.M.S. Silva 2011: Oxidation mechanisms occurring in wines. Food Res. Int. 44, 1115-1126.

OUGH, C.S 1969: Substances extracted during skin contact with white must. I. General wine composition and quality changes with contact time. Am. J. Enol. Vitic. 20, 93100.

PezZI, F. and C. CAPRARA 2009: Mechanical grape harvesting: investigation of the transmission of vibrations. Biosys. Eng. 103, 281-286.

Robards, K., P.D. Prenzler, G. Tucker, P. Swatsitang and W. Glover 1999: Phenolic compounds and their role in oxidative processes in fruits. Food Chem. $66,401-436$. 
Ruiz-García, Y., I. Romero-Cascales, R. Gil-Muñoz, J.I. FernándeZ-FernándeZ, J.M. LÓPEZ-ROCA and E. GÓMEZ-PLAZA 2012: Improving grape phenolic content and wine chromatic characteristics through the use of two different elicitors: methyl jasmonate versus benzothiadiazole. J. Agric. Food Chem. 60, 1283-1290.

Ribereau-Gayon, P. and Y. Glories 1987: Phenolics in grape and wines. In: LeE, T. (ed.): Proc. $6^{\text {th }}$ Australian Wine Industry Technical Conference. Australian Industrial Publishers, Adelaide, 247-256.

Singleton, V.L., J. ZAYA, E. TRousLAde and M.SAlgues 1984: Caftaric acid in grapes and conversion to a reaction product during processing. Vitis $23,113-120$.

Uzquiza L., R. GonzÁLeZ, M.R. GonzÁlez and P. MARtín 2013: Potential of combined ethephon and methyl jasmonate treatments for improving mechanical harvesting of wine grapes. Europ. J. Hort. Sci. 78, 169-175.

UZQUIZA L., R. GonZÁleZ, M.R GonZÁLEZ and P. MARTín 2014a: Aplicaciones de etefón y metil jasmonato para facilitar el desprendimiento del fruto en vides cv. Sauvignon blanc. In: Ayuga F., A. Masaguer, I. Mariscal, M. Villarroel, M. Ruiz-Altisent, F. RIQUelme and E.C. CorReA HeRnANdo (eds.): Proc. $7^{\text {th }}$ Congreso lbérico de Agroingeniería y Ciencias Hortícolas: Innovar y producir para el futuro. Madrid, 115-120.

Uzquiza, L., P. Martin, J.R. Sievert, M.L. Arpaia and M.W. Fidelibus 2014b: Methyl jasmonate and 1-aminocyclopropane-1-carboxylic acid interact to promote grape berry abscission. Am. J. Enol. Vitic. 65, 504-509. 


\section{DISCUSIÓN GENERAL}




\section{DISCUSION GENERAL.}

En los Capítulos III, IV y V se han expuesto y discutido de forma individual los resultados obtenidos de cada uno de los tres ensayos que constituyen esta Tesis Doctoral. En este apartado se discuten de forma conjunta los resultados de todo el trabajo.

\section{VI.1. Abscisión de la uva.}

La aplicación de metil jasmonato (MeJA), ácido 1-aminociclopropano-1carboxílico (ACC) y etefón ha presentado un efecto significativo en la abscisión de la baya, reduciendo la fuerza de desprendimiento del fruto (FDF). Tanto el MeJA como el ACC han favorecido la presencia de tejido cicatricial en la zona de inserción del pedicelo (Capítulos III y IV). Se ha detectado un efecto positivo de la aplicación de ACC en la producción endógena de etileno en las bayas.

En todos los ensayos realizados se han registrado diferencias interanuales importantes en los resultados, debido probablemente a que los cambios en las condiciones ambientales entre una y otra campaña modifican la eficiencia de los productos aplicados. Estas diferencias son habituales en los ensayos de agentes de abscisión (Peterson y Hedberg, 1975; Szyjewicz et al., 1984; Fidelibus et al., 2007; González-Herranz et al., 2009; Malladi et al., 2012). La temperatura en el momento de tratamiento es un factor importante, así por ejemplo Quaglino et al. (1981) han observado un mayor efecto del etefón sobre la abscisión cuando se aplica en las horas más cálidas del día. La presencia de precipitaciones posteriores a la aplicación de los tratamientos puede lavar parcialmente los productos, reduciendo así su efectividad (Mortensen, 1980). Por otra parte, el diferente grado de madurez del fruto en cada campaña en el momento de la aplicación también podría generar distinta intensidad de respuesta (Fidelibus et al., 2007), si bien en el presente estudio, este efecto se ha minimizado tratando las uvas cuando habían alcanzado un contenido de sólidos solubles similar en las diferentes campañas.

Los tratamientos con agentes de abscisión han generado diferentes intensidades de respuesta dependiendo del cultivar en el que se han aplicado. Así, el MeJA ha producido reducciones más intensas y más tempranas de la FDF en cv. Thompson seedless que en cv. Verdejo. Las aplicaciones han dado lugar a una caída prematura de frutos significativa frente a los testigos sin tratar en el primer cultivar, y no significativa en el segundo. Estas diferencias en la intensidad de los efectos de 
MeJA a favor de la variedad apirena podrían tener que ver con el hecho de que la ausencia de semillas en el fruto disminuiría la concentración de auxinas frente a la variedad pirena aumentando la respuesta al etileno y promoviendo la abscisión (Taylor y Whitelaw, 2001).

El MeJA ha empezado a reducir la FDF frente a los testigos en uva cv. Thompson seedless (Ensayo 2), a concentración $1335 \mathrm{mg} \cdot \mathrm{L}^{-1}$, dos días después de su aplicación, manteniéndose una disminución media del 38\% (Tabla IV.2). GonzálezHerranz et al. (2009), aplicando concentraciones mayores de MeJA (2240 y 4485 $\mathrm{mg} \cdot \mathrm{L}^{-1}$ ) en la misma variedad observaron el mismo período de respuesta, un parámetro que, a la luz de estos resultados, podría ser independiente de la concentración de producto aplicada.

La eficiencia de los tratamientos en cultivares pirenos presenta grandes variaciones intervarietales. La reducción de FDF obtenida en 'Verdejo' es similar a la registrada en 'Sauvignon blanc' por Uzquiza et al. (2014a), pero está lejos del 71\% observado por Fidelibus et al. (2007) a los 14 días de su aplicación en 'Merlot' y 'Cabernet sauvignon'.

La reducción de la FDF en cv. Thompson seedless tras aplicar MeJA (1344 $\mathrm{mg} \cdot \mathrm{L}^{-1}$ ) ha ocasionado una caída prematura de bayas tres días después de su aplicación, en torno al 13\% (Ensayo 2, Capítulo IV). En este estudio la recomendación de dosis de MeJA a aplicar formulada por Fidelibus y Cathline (2010), menos de 890 $\mathrm{mg} \cdot \mathrm{L}^{-1}$, no sería válida para reducir la FDF sin producir una caída prematura de frutos excesiva. En cv. Verdejo la aplicación de MeJA no ha ocasionado una caída prematura de frutos significativa frente a los controles (Ensayo 1 y 3). Fidelibus et al. (2007a) aplicando MeJA en uva cv. Merlot y cv. Cabernet sauvignon han observado una caída prematura del 10\%. Uzquiza et al. (2014a) registraron el 3\% en cv. Sauvignon blanc. La aplicación de MeJA a concentraciones de $4485 \mathrm{mg} \cdot \mathrm{L}^{-1}$ en arándano (Vaccinium spp.), o de entre $11125 \mathrm{mg} \cdot \mathrm{L}^{-1}$ y $222,5 \mathrm{~g} \cdot \mathrm{L}^{-1}$ en cítricos (Citrus sinensis (L.) Osb.), indujo una rápida y extensiva abscisión de frutos (Malladi et al., 2012; Hartmond et al., 2000).

Las aplicaciones de MeJA estudiadas en las diferentes pruebas, han presentado un efecto promotor de la cicatrización de la capa de abscisión, tal y como ha sido observado en 'Thompson seedless' por González-Herranz et al. (2009), Fidelibus y Cathline (2010) y en cv. Sauvignon blanc por Uzquiza et al. (2014a). El efecto del MeJA en la cicatrización de las bayas en la zona de abscisión ha empezado a ser significativo antes en cv. Thompson seedless que en cv. Verdejo, al igual que 
ocurría con la reducción de la FDF. La presencia de tejido cicatricial contribuye a evitar así la liberación de mosto y su consiguiente exposición a la oxidación (Meyer, 1969), a la vez que elimina puntos de entrada para el ataque de microorganismos (Ballinger y Nesbitt, 1982; Kou et al., 2007).

La aplicación de tratamientos de MeJA ha tendido a incrementar la producción de etileno en uva aunque las diferencias no fueron estadísticamente significativas frente a los controles (Capítulo IV). Diversos autores han encontrado incrementos significativos tanto en frutos climatéricos (Fan et al., 1998; Saniewski et al., 1987a; Saniewski et al., 1987 b; Ozturk et al., 2014; Khan y Singh, 2010) como no climatéricos (Hartmond et al., 2000; Kender et al., 2001). Se ha observado además que la aplicación de MeJA produce un incremento de los niveles de las enzimas ACS y ACO, implicadas en los últimos pasos de la síntesis de etileno; por ejemplo, en aplicaciones a concentración $111,2 \mathrm{mg} \cdot \mathrm{L}^{-1}$ de MeJA previas al punto de madurez en fresa Fragaria ananassa (Mukkun y Singh, 2009), Fragaria chiloensis (Concha et al., 2013) en diferentes estados de madurez, a concentración $22,4 \mathrm{mg} \cdot \mathrm{L}^{-1}$ posteriores a la recolección de ciruela Prunus salicina Lindl. (Khan y Singh, 2007) y a concentración 87 $\mathrm{mg} \cdot \mathrm{L}^{-1}$ en pera Pyrus communis L. (Kondo et al., 2007).

Parece claro que el MeJA interviene en la abscisión al menos en parte, promoviendo la síntesis de etileno en los tejidos del fruto. Malladi et al. (2012) han observado que aplicaciones de MeJA combinado con aminoetoxivinilglicina (AVG, inhibidor de la síntesis de etileno) en arándano cv. Powderblue provocan reducciones inferiores en la FDF que las obtenidas con MeJA solamente. Sin embargo, tanto el incremento limitado de la curva de producción de etileno endógeno del MeJA en el Ensayo 2, como el hecho de que este producto tenga un efecto mucho más intenso en la cicatrización de las bayas que los liberadores de etileno, apunta a que existen mecanismos alternativos de acción del MeJA sobre la abscisión independientes del etileno.

Los trabajos realizados por Hartmond et al. (2000) y Kender et al. (2001) en naranjo son los únicos en la bibliografía en los que se han estudiado simultáneamente los efectos de la aplicación de MeJA en la producción endógena de etileno del fruto, la FDF y la caída prematura de frutos. Hartmond et al. (2000) observaron que tratamientos de MeJA de hasta $4485 \mathrm{mg} \cdot \mathrm{L}^{-1}$ sobre la vegetación de los árboles, previos a la cosecha incrementaban la producción de etileno en las naranjas, con un máximo un día después de la aplicación, y favorecían su abscisión en los días posteriores. Por otra parte, Kender et al. (2001) al comparar los efectos de la aplicación de MeJA 
aisladamente y combinado con 5-cloro-3-metil-4-nitro-1H-pirazol (CMNP), y observaron que en naranjas 'Hamlin' la producción de etileno un día después de la aplicación se incrementaba significativamente con el tratamiento combinado. Este tratamiento ocasionaba una mayor caída de frutos que las pulverizaciones simples de MeJA.

La formación de ACC, en la que interviene la enzima ACS, se considera la etapa limitante en la biosíntesis de etileno. Las uvas tratadas con ACC (Ensayo 2) han presentado una mayor producción de etileno que los controles a partir de dos días después de su aplicación, mostrando valores más o menos constantes durante 10 días. A diferencia de lo observado con los tratamientos de etefón, el ACC ha promovido la aparición de cicatriz de la zona de abscisión del fruto de forma diferenciada. Investigaciones recientes sugieren que el ACC podría actuar como regulador del desarrollo de las plantas con independencia de su papel como promotor de etileno (Yoon y Kieber, 2013).

El efecto de los tratamientos de ACC sobre la FDF ha sido similar al registrado por Fidelibus et al. (2007a) con dosis muy inferiores $\left(50 \mathrm{mg} \cdot \mathrm{L}^{-1}\right)$. Lógicamente, la acción de los agentes de abscisión es modificada por las condiciones ambientales y de cultivo.

Las aplicaciones de ACC y etefón han mantenido sus efectos sobre la abscisión de los frutos hasta el momento de la vendimia, aunque ambos fitorreguladores han presentado diferencias en el momento de empezar a manifestar su actividad. Sin embargo en este aspecto ACC y MeJA han proporcionado un comportamiento parecido. El ACC aplicado aisladamente en uva cv. Thompson seedless ha promovido la producción de etileno y ha reducido la FDF tan solo un día después del tratamiento, mientras que el MeJA tuvo un efecto significativo sobre la FDF y promoción de cicatriz de la zona de abscisión a los dos días de su aplicación. En la variedad 'Verdejo' (Ensayo 1) el etefón ha producido reducciones significativas de la FDF antes que el MeJA.

Las aplicaciones de ACC en uva cv. Thompson seedless han promovido la cicatrización de la zona de abscisión, alcanzando un valor medio al final del Ensayo 2, del $34 \%$ de las bayas. El etefón en 'Verdejo' no incrementó significativamente la presencia de tejido cicatricial en contra de lo observado por Morris y Cawthon (1981) y Rizzuti et al. (2015), con dosis de producto a partir de $400 \mathrm{mg} \cdot \mathrm{L}^{-1}$, en cv. Concord y cv. Crimson seedless, respectivamente. La presencia de una cicatriz seca en la zona de abscisión podría ser un efecto deseable también en uva de mesa para su 
comercialización en granos separados como producto de cuarta gama, ya que podría reducir el uso de antioxidantes y alargar la vida comercial de la fruta.

Los tratamientos combinados de MeJA tanto con etefón como con ACC, han proporcionado resultados más interesantes que los obtenidos con los productos por separado, con valores menores de la FDF y niveles de cicatrización de la zona de abscisión que alcanzan el $75 \%$ de las bayas. En el Ensayo 1 se ha puesto de manifiesto un efecto aditivo del etefón y MeJA en la reducción de la FDF de uva cv. Verdejo, en la misma línea que experiencias similares en 'Sauvignon blanc' (Uzquiza et al., 2014a; Uzquiza et al., 2014b), así como un efecto sinérgico de los dos agentes sobre la cicatrización de la zona de abscisión. En el Ensayo 2 se ha observado una interacción positiva de MeJA y ACC en la reducción de la FDF, la promoción de la cicatrización de la capa de abscisión y la producción endógena de etileno en uva cv. Thompson seedless.

La caída prematura de frutos también se vio potenciada con las aplicaciones combinadas con ACC en 'Thompson seedless' (36\% en peso de bayas caídas), pero no con etefón en cv. Verdejo (valores que no han superado el 1\%). Los registros en la variedad 'Verdejo' son menores al 3,1\% observado en 'Sauvignon blanc' con dosis y situaciones de cultivo similares (Uzquiza et al., 2014a). ACC y MeJA han mostrado un efecto sinérgico en la caída prematura de frutos (Tabla IV.3), que se produce con posterioridad al incremento de la concentración de etileno en los frutos.

La existencia de efectos aditivos y de interacción entre agentes de abscisión es un aspecto muy interesante desde el punto de vista práctico, ya que la utilización de aplicaciones combinadas contribuye a disminuir las dosis de producto, reduciendo a su vez los niveles de residuos en los frutos y los costes del tratamiento. Así por ejemplo Kender et al. (2001) han observado que aplicaciones combinadas de MeJA y CMNP en naranjo, promueven una mayor síntesis de etileno que los productos aplicados por separado y permiten reducir hasta 10 veces la concentración de MeJA y 2 veces la de CMNP para conseguir el mismo efecto, sin provocar defoliación en los árboles.

Ni la aplicación de etefón ni de ACC por separado ha presentado una caída prematura de frutos significativa frente a los controles a lo largo de los ensayos realizados, pese a sus efectos reductores de la FDF. Este hecho convierte a estos dos fitorreguladores en productos potencialmente interesantes para facilitar la vendimia mecanizada. Sin embargo, los tratamientos simple de MeJA con las dosis más altas sí han supuesto una pérdida potencial de cosecha significativa en la variedad 'Thompson seedless' debida a la caída de frutos, a partir de 3-5 días de su aplicación (Ensayo 2). 
Aunque los resultados no se han mostrado en el capítulo III, en el Ensayo 1 se analizó el posible efecto defoliador de los tratamientos con los agentes de abscisión en el mes posterior a su aplicación. La superficie foliar total de las viñas y el porcentaje de hojas con coloración amarilla-marrón no fue significativamente diferente entre tratamientos con etefón y/o MeJA y controles sin tratar, de acuerdo con lo que otros autores han observado con tratamientos de etefón en viñedo (Eynard, 1970; Hedberg y Goodwin, 1980; El-Zeftawi, 1982), o de MeJA en naranjo (Kender et al., 2001). Dado que el etefón aplicado podría tener algún efecto en la brotación de las yemas (Hale et al., 1970; Hirschfeld y Lavee, 1980), en el presente estudio también se controló la brotación de las yemas francas en la primavera siguiente a la aplicación de los agentes de abscisión, sin observarse retrasos en las cepas tratadas frente a las cepas testigo. En este sentido los tratamientos, tal y como se aplicaron, no han tenido ningún efecto colateral en procesos ajenos a la abscisión del fruto.

\section{VI.2. Rendimiento de la vendimia mecanizada.}

Como se ha podido observar en el Ensayo 3 (Capítulo V), la promoción de la abscisión de uva con la aplicación de etefón y MeJA ha dado lugar a pérdidas de cosecha durante la vendimia mecanizada, variables en función de la frecuencia de los sacudidores empleada en la máquina. Las pérdidas fueron significativas vendimiando a 425 golpes $\cdot \mathrm{min}^{-1}$ pero no difirieron de los controles a $400 \mathrm{golpes} \cdot \mathrm{min}^{-1}$. La razón de este mayor nivel de pérdidas está en que al disminuir la FDF, es mayor la cantidad de frutos que caen al suelo de las plantas próximas a las que están siendo cosechadas por la máquina debido a las vibraciones trasmitidas a través del sistema de empalizamiento (Figura V.1). Los resultados del Ensayo 3 coinciden con los de un estudio similar en 'Sauvignon blanc', donde no se observaron diferencias en el rendimiento de vendimia entre tratamientos experimentales trabajando a 410 golpes $\cdot \min ^{-1}$. Es importante destacar, en cualquier caso, que las pérdidas de cosecha en las plantas tratadas con agentes de abscisión se podrían reducir con un ajuste adecuado del régimen de trabajo de la maquina vendimiadora.

La aplicación de etefón y MeJA no supuso ninguna modificación, respecto a los controles, en la cantidad de bayas y racimos que quedaban en la planta sin recoger (pérdidas en planta) para las frecuencias de sacudido estudiadas. Con independencia de esto, las pérdidas en planta fueron mayores a medida que aumentaba la frecuencia de sacudido en 2013, tal y como se ha puesto de manifiesto en otros trabajos (Arfelli et al., 2010; Pezzi y Caprara, 2009). 
Al contrario de lo que ocurre en el viñedo de vinificación, la caída de frutos al suelo después de los tratamientos con agentes de abscisión puede ser un aspecto interesante para la producción de uva de pasificación, donde las uvas deprendidas quedarían en el suelo sobre láminas de papel continuo, listas para su secado natural (Christensen, 2000). Con esta técnica las bayas resultarían menos dañadas físicamente por el trabajo de la vendimiadora y tendrían una mayor presencia de cicatriz en la zona de abscisión, lo que evitaría la liberación de mosto y redundaría positivamente en la calidad del producto final (Studer, 2000). Los agentes de abscisión podrían sustituir a la técnica tradicional de secado en California, consistente en cortar las varas de producción con la fruta al final de la maduración para que se seque en la propia cepa (Fidelibus et al., 2008).

Los tratamientos con MeJA y etefón, en la medida que han favorecido el desprendimiento de las uvas y la cicatrización de las zonas de abscisión, han tendido a disminuir la liberación de mosto durante la vendimia mecanizada. Sin embargo, la proporción de mosto libre en la masa recogida, al igual que las pérdidas de cosecha por caída de frutos al suelo, han mostrado valores diferentes según la frecuencia de los sacudidores de la máquina. Así, los tratamientos redujeron el mosteo (20,6\% en cepas tratadas frente a $23,2 \%$ en los controles) con el régimen de trabajo más intenso, mientras que las diferencias frente a los controles no fueron significativas con el régimen más ligero. Arfelli et al. (2010) no observaron diferencias significativas en el mosto liberado comparando diferentes frecuencias de vibración, al contrario que otros autores (Pezzi y Caprara, 2009). Las propiedades mecánicas de la uva como la resistencia a la rotura, la regulación de otros parámetros de la máquina vendimiadora diferentes a la frecuencia de los sacudidores, y las características específicas del sistema de conducción del viñedo, serían factores adicionales a considerar en el porcentaje de mosteo durante la vendimia mecanizada.

Por todo lo comentado, la aplicación de agentes de abscisión podría ser interesante para incrementar la frecuencia de sacudido en la vendimia mecanizada y así disminuir la proporción de mosto libre en la masa recogida. Hay que tener presente que los regímenes de trabajo más enérgicos podrían incrementar las pérdidas de cosecha. Por otra parte, la aplicación de agentes de abscisión podría reducir el tiempo invertido en la vendimia mecanizada y el gasto de combustible (Mortensen, 1980).

\section{VI.3. Composición de mostos y vinos.}

La influencia de los tratamientos experimentales sobre la composición de los mostos ha sido analizada en los Ensayos 1 y 3 (Capítulos III y V, respectivamente) y 
sobre la calidad de los vinos en el Ensayo 3. Tanto en mostos como en vinos el factor campaña ha tenido un efecto significativo. No se han observado interacciones entre el etefón y MeJA, ni entre los tratamientos combinados de ambos fitorreguladores y los métodos de vendimia sobre la composición de mostos (con excepción del contenido de sólidos solubles) y vinos.

La acidez total de los mostos se ha visto incrementada por los tratamientos de MeJA a $8960 \mathrm{mg} \cdot \mathrm{L}^{-1}$ (Ensayo 1) y de MeJA combinado con etefón (año 2011, Ensayo 3). Fidelibus et al. (2007) observaron reducciones en la acidez en mostos cv. Cabernet sauvignon, 14 días de aplicar MeJA a concentración $4500 \mathrm{mg} \cdot \mathrm{L}^{-1}$ pero no observaron efectos significativos frente a los controles en cv. Merlot. En trabajos recientes se ha observado que aplicaciones de MeJA en vid durante el envero (Ruiz-García et al., 2012, 2013) tienden a aumentar los niveles de acidez en los mostos de vendimia frente a los testigos sin tratar.

Diferentes autores han demostrado que tratamientos postcosecha de MeJA contribuyen a mantener los niveles de acidez en rábano (Wang, 1998), melocotón (Jin et al., 2006) o frambuesa (Ghasemnezhad y Javaherdashti, 2008). Khan y Singh (2007) han observado que los frutos tratados con MeJA incrementaban el contenido en sólidos solubles y reducían la acidez total durante la maduración de ciruelo japonés. En frambuesa (Rubus idaeus L.) la aplicación de MeJA puede incrementar el contenido en azúcares solubles y retrasar la pérdida de ácidos orgánicos durante el almacenamiento (Wang, 2003).

Las aplicaciones combinadas de etefón y MeJA, con diferentes intensidad unos años y otros, han tendido a reducir la concentración de potasio en el mosto con independencia del método de vendimia empleado. Este efecto podría considerarse positivo en la vendimia mecanizada, donde la maceración con los hollejos que ocurre durante el proceso de recolección y el posterior transporte a la bodega puede incrementar el contenido de cationes inorgánicos del mosto (Ough, 1969; Guerzoni et al., 1981; Arfelli et al., 2010).

El contenido polifenólico y las características colorimétricas de mostos y vinos han sido alteradas tanto por la aplicación de etefón y MeJA como por el método de vendimia. El contenido fenólico total se ha visto significativamente incrementado por la aplicación combinada de etefón y MeJA en el Ensayo 3. A pesar de que los tratamientos se dan muy cercanos a la vendimia, los fitorreguladores tendrían un efecto significativo en la biosíntesis de polifenoles, como ocurre cuando son aplicados a comienzos de la maduración. Numerosos autores han observado que aplicaciones 
de liberadores de etileno como el etefón (Mazza, 1995; Delgado et al., 2004; Gallegos et al., 2006) o MeJA (Gómez-Plaza et al., 2012, 2013) en torno al envero incrementan la concentración de polifenoles en uva. Se ha observado que el MeJA modula la síntesis de polifenoles activando de forma coordinada la expresión de múltiples genes (Gozzo, 2003).

La absorbancia a $320 \mathrm{~nm}$ está relacionada con el contenido de hidroxicinamatos (polifenoles potencialmente oxidables), mientras que la absorbancia a $420 \mathrm{~nm}$ representa la intensidad colorante, con valores mayores cuanto más avanzado es el estado de oxidación de los polifenoles. La oxidación se debe a la actividad de la enzima polifenoloxidasa (PPO), que una vez se ha producido la rotura de bayas y la liberación de mosto (Robards et al., 1999), produce pardeamiento y pérdida de calidad aromática del mismo (Nagel y Graber, 1988). En el presente estudio, el incremento significativo de la absorbancia a $320 \mathrm{~nm}$ de mostos procedentes de uva tratada con etefón y MeJA frente a los controles, podría estar relacionado con el incremento polifenólico experimentado en las uvas tratadas, pero también con la presencia de más bayas cicatrizadas en la zona de abscisión y con la reducción en la liberación de mosto, que limitaría el nivel de oxidación de la pasta vendimiada mecánicamente.

Existen sistemas enzimáticos de las plantas que pueden estar inducidos por los jasmonatos (Rowher y Erwin, 2008). Se ha observado que la actividad de la PPO se ve favorecida con aplicaciones de jasmonatos en hojas de diferentes plantas como alubia (Alba-Meraz y Choe, 2002) o tomate (Boughton et al., 2006). Es posible que los tratamientos aplicados en los Ensayos 1 y 3 hayan inducido también la actividad de la PPO en los frutos, dando lugar a valores mayores de las absorbancias a $420 \mathrm{~nm}$ que en los controles.

Los métodos de vendimia, manual y mecanizada, no tuvieron ningún efecto en la concentración de polifenoles totales, a pesar de que con la liberación de mosto en la pasta vendimiada mecánicamente, se produce una maceración durante la vendimia y transporte a bodega que tendería a aumentar la extracción de polifenoles de los hollejos. Tampoco se obtuvieron diferencias comparando las dos frecuencias de los sacudidores, a diferencia de lo mostrado por Pezzi et al. (2005), que observaron mayor contenido fenólico en mostos procedentes de vendimias con regímenes de trabajo más intensos.

Los parámetros fisicoquímicos analizados en los vinos han sido poco afectados por los tratamientos de campo y los métodos de vendimia en el Ensayo 3, si bien es de 
destacar que la aplicación de agentes de abscisión dio lugar a vinos con mayor contenido polifenólico. Arfelli et al. (2010) no observaron cambios importantes en la composición fisicoquímica de los vinos relacionados con el tipo de recolección salvo valores mayores de $\mathrm{pH}$ en vendimia mecánica que en recogida manual.

La estabilidad oxidativa de los vinos no ha presentado diferencias estadísticas en función de la aplicación de agentes de abscisión. Tampoco ha habido diferencias con respecto al método de vendimia, en contra de lo observado por Arfelli et al. (2010) en cv. Montuni.

Los resultados obtenidos con la aplicación combinada de etefón y MeJA, en cv. Verdejo han sido similares a los registrados en uva 'Sauvignon blanc' (Uzquiza et al., 2014b): poco efecto en el contenido de azucares y ácidos del mosto e incrementos del índice de polifenoles totales, contenido en ácidos cinamiltartáricos e intensidad colorante. Los vinos cv. Sauvignon blanc procedentes de uvas tratadas no mostraron cambios en los parámetros de composición analizados ni en la estabilidad oxidativa frente a los controles, pero si presentaron una mayor intensidad colorante (absorbancia a $420 \mathrm{~nm}$ ), a diferencia de lo observado en cv. Verdejo.

Por todo lo comentado, la aplicación de MeJA en prevendimia combinado con ACC o etefón muestra un gran interés para favorecer el proceso de abscisión de la uva. Estos tratamientos, junto a la regulación del régimen de trabajo de la vendimiadora, permitirían mejorar el rendimiento de la máquina y reducir la liberación de mosto en la pasta recogida. Los resultados muestran que los tratamientos con etefón más metil jasmonato han mejorado la calidad del mosto cv. Verdejo elevando la concentración de ácidos hidroxicinámicos y disminuyendo el contenido en potasio, si bien, no han afectado a la estabilidad oxidativa de los vinos. 
VII. CONCLUSIONES 


\section{CONCLUSIONES}

Del estudio realizado se pueden extraer las siguientes conclusiones:

1. La aplicación individual de metil jasmonato (MeJA), etefón y ácido 1aminociclopropano-1-carboxílico (ACC) sobre los racimos en los días previos a la vendimia ha reducido significativamente la fuerza de desprendimiento de la uva entre 1 y 8 días después del tratamiento, en función del producto y del cultivar estudiado. Tanto MeJA como ACC han promovido, frente a testigos sin tratar, la cicatrización de la zona de abscisión de las uvas.

2. Las aplicaciones combinadas han puesto de manifiesto un efecto aditivo entre MeJA y etefón, y un efecto sinérgico entre MeJA y ACC en la reducción de la fuerza de desprendimiento del fruto. Las aplicaciones conjuntas han registrado, además, un porcentaje mayor de uvas con cicatriz en la zona de inserción del pedicelo que las aplicaciones individuales. En las condiciones de cultivo estudiadas los mejores resultados se han obtenido con $8960 \mathrm{mg} \cdot \mathrm{L}^{-1} \mathrm{MeJA}+1000 \mathrm{mg} \cdot \mathrm{L}^{-1}$ etefón ocho días después de su aplicación en cv. Verdejo y $1335 \mathrm{mg} \cdot \mathrm{L}^{-1} \mathrm{MeJA}+1000 \mathrm{mg} \cdot \mathrm{L}^{-1} \mathrm{ACC}$ a partir de dos días del tratamiento en cv. Thompson seedless.

3. La producción endógena de etileno de la uva se ha visto favorecida por la aplicación en prevendimia de ACC y ha registrado una interacción positiva con la aplicación de MeJA. Esto justificaría la mayor efectividad de los tratamientos combinados frente a los individuales en la estimulación de los procesos relacionados con la abscisión.

4. El hecho de que el tratamiento de MeJA no haya modificado por si mismo la producción de etileno en la uva, junto a un efecto mayor sobre la cicatrización de la zona de inserción del pedicelo que el etefón o ACC, indicaría que la actividad del MeJA sobre los procesos de abscisión de la uva no se ejercería exclusivamente a través del etileno. 
5. La aplicación de MeJA, solo o combinado con ACC, en uva cv. Thompson seedless ha provocado unas pérdidas significativas de cosecha de hasta el $36 \%$ como consecuencia de la caída prematura de bayas antes de la vendimia. Sin embargo los tratamientos individuales de MeJA, etefón, o la combinación de ambos fitorreguladores en viñedo cv. Verdejo no han registrado pérdidas significativas ni tampoco han producido defoliación de las plantas o retraso en la brotación de yemas francas en el ciclo posterior a la aplicación.

6. Los tratamientos combinados de etefón $\left(1000 \mathrm{mg} \cdot \mathrm{L}^{-1}\right)$ y MeJA (8960 mg $\left.\cdot \mathrm{L}^{-1}\right)$ diez días antes de la recolección en uva cv. Verdejo no han afectado al rendimiento de la vendimia mecanizada, cuando la frecuencia de sacudido de la maquina era 400 golpes $\min ^{-1}$. Sin embargo, con regímenes de trabajo más enérgicos las pérdidas de cosecha podrían incrementarse al aumentar la proporción de uvas caídas al suelo durante el proceso. Con independencia del tratamiento prevendimia las pérdidas totales y el porcentaje de uva que quedo en las plantas sin recoger disminuyeron al aumentar la frecuencia de sacudido.

7. Al facilitar el desprendimiento de la uva y promover la cicatrización de la zona de abscisión, la aplicación combinada de etefón y MeJA ha tendido a reducir el volumen de mosto liberado durante la vendimia mecánica, con diferencias destacadas frente a los controles cuando se utilizaba el régimen de trabajo de la máquina más intenso.

8. La reducción del mosteo, la menor proporción de uva dañada mecánicamente, así como la cicatrización de la zona de abscisión en las uvas tratadas con etefón y MeJA han tenidos efectos positivos en la composición del mosto. Así se ha constatado una tendencia a disminuir la concentración de potasio (maceración menos intensa) y un incremento de la cantidad de ácidos cinamiltartáricos (polifenoles no oxidados), en frutos tratados frente a controles sin tratar.

9. La aplicación combinada de etefón y MeJA incrementó el contenido polifenólico total de mostos y vinos cv. Verdejo, pero no tuvieron un efecto claro sobre la 
intensidad colorante de los mismos. Los tratamientos no afectaron al pH, acidez o a la estabilidad oxidativa de los vinos.

10. En definitiva, el trabajo realizado demuestran que existe un gran potencial en el uso de los agentes de abscisión en uva de vinificación para mejorar el rendimiento de la vendimia mecanizada y la calidad del mosto y del vino. 
VIII.BIBLIOGRAFÍA 


\section{BIBLIOGRAFÍA.}

ABELES, F.B., MORGAN, P.W. y SALTVEIT, M.E. Jr. 1992. Ethylene in plant biology, $2^{a}$ edición. San Diego: Academic Press. Pag 414.

ADDICOTT, F.T. 1968. Environmental factors in the physiology of abscission. Plant physiology, 43: 1471-1479.

ADDICOTT, F.T. 1982. Abscission. University of California Press. Berkekey, California.

ALBA-MERAZ, A. y CHOE, H.T. 2002. Systemic effects on oxidative enzymes in Phaseolus vulgaris leaves that have been wounded by the grasshopper Melanoplus differentialis (Thomas) or have had a foliar application of jasmonic acid. International Journal of Plant Sciences, 163: 317-328.

AlleN, T., HeRBSt-JOHNStONE, M., GIRAUlt, M., BUtLER, P., LOGAN, G., JOUANNEAU, S., NICOLAU, L. y KILMARTIN, P. 2011. Influence of grapeharvesting steps on varietal thiol aromas in Sauvignon Blanc wines. Journal of Agricultural and Food Chemistry, 59: 10641-10650.

AMRHEIN, N., SCHNEEBECK, D., SKORIPKA, H., TOPHOF, S. y STOCKIGT, J. 1981. Identification of a major metabolite of the ethylene precursor 1aminocyclopropane-1-carboxylic acid in higher plants. Naturwissenschaften, 68: 619-620.

ARFELLI, G., SARTINI, E., BORDINI, F., CAPRARA, C. y PEZZI, F. 2010. Mechanical harvesting optimization and postharvest treatments to improve wine quality. Journal International des Sciences de la Vigne et du Vin, 44: 101-115.

AYALA-ZAVALA, J. F., SHIOW, Y.W., CHIEN, Y. W. y GONZÁLEZ-AGUILAR, G. 2005. Methyl jasmonate in conjunction with ethanol treatment increases antioxidant capacity, volatile compounds and postharvest life of strawberry fruit. European Food Research and Technology, 221: 731-738.

BALDINI, E. e INTRIERI, C. 2004. Viticoltura meccanizzata: scelta delle macchine, adeguamento dei vigneti, valutazioni economiche, organizzazione del lavoro. Edagricole, Bologna, Italia.

BALDWIN, I.T. 1998. Jasmonate-induced responses are costly but benefit plants under attack in native populations. Proceedings of the National Academy of Sciences, of the United States of America, 95: 8113-8118.

BALLINGER, W.E. y NESBITT, W.B. 1982. Postharvest decay of muscadine grapes (Carlos) in relation to storage temperature, time and stem condition. American Journal of Enology and Viticulture, 33: 173-175. 
BARRANCO, D., ARQUERO, O., NAVARRO. C. y RAPOPORT, H.F. 2004. Monopotassium phosphate for olive fruit abscission. Hortscience, 39: 13131314.

BARRANCO, D., DE TORO, C.C., ORIA, M. y RAPOPORT, H.F. 2002. Monopotassium Phosphate for olive fruit abscission. Acta Horticulturae, 586:263-266.

BENO-MOUAleM, D., GUSEV, L., DVIR, O., PESIS, E., MEIR, S. y LICHTER, A. 2004. The effects of ethylene, methyl jasmonate and 1-MCP on abscission of cherry tomatoes from the bunch and expression of endo-1,4- $\beta$-glucanases. Plant Science, 167: 499-507.

BEŠLIĆ, Z. 2009. Uticaj odnosa vegetativne mase i prinosa na fiziološke i agrobiološke osobine vinove loze. Doktorska disertacija. Poljoprivredni fakultet, Beograd.

BOUGHTON, A.J., HOOVER, K. y FELTON, G.W. 2006. Impact of chemical elicitor applications on greenhouse tomato plants and population growth of the green peach aphid, Myzus persicae. Entomologia Experimentalis et Applicata, 120:175-188.

BOWER, N.I., CASU, R.E., MACLEAN, D.J., REVERTER, A., CHAPMAN, S.C. y MANNERS, J.M. 2005. Transcriptional response of sugarcane roots to methyl jasmonate. Plant Science, 168: 761-772.

BRADSHAW, M.P., PRENZLER, P.D., y SCOLLARY, G.R. 2001. Ascorbic acidinduced browning of $(+)$-catechin in a model wine system. Journal of Agricultural and Food Chemistry, 49: 934-939.

BROWN, K.M. 1997. Ethylene and abscission. Physiologia Plantarum, 100: 567-576.

BURNS, K.J., FERGUSON, L., GLOZER, K., KRUEGER, H.W. y ROSECRANCE, C.R. 2008. Screening fruit loosening agents for black ripe processed table olives. HortScience 43, 1449-1453.

BURNS, J.K., POZO, L.V., ARIAS, C.R., HOCKEMA, B., RANGASWAMY, V. y BENDER, C.L. 2003. Coronatine and abscission in citrus. Journal of the American Society for Horticultural Science, 128: 309-315.

CAPRARA, C y PEZZI, F. 2014. Evaluation of quality of harvest and mechanical aspects related to beater adjustments in mechanical grape harvesting. Agricultural Engineering, 57: 991-997.

CATANIA, P., VALLONE, M. y PIPITONE, F. 2009. Analysis of the main factors influencing the quality of wine from mechanical harvested grapes. Rivista di Ingegneria Agraria, 4: 35-38. 
CHALER, G. 1991. Récolte mécanique de la vigne: comportement des nouveaux dispositifs de récolte. (Mechanical harvesting of vineyard: behavior of new harvesting devices). Progrès Agricole et Viticole, 108: 79-86.

CHEYNIER, V. F., TROUSDALE, E. K., SINGLETON, V. L., SALGUES, M. J., y WYLDE, R. 1986. Characterization of 2-S-glutathioylcaftaric acid and its hydrolysis in relation to grape wines. Journal of Agricultural and Food Chemistry, 34: 217-221.

CHRISTENSEN, L.P. 2000. Current developments in harvest mechanization and DOV. En: L.P. Christensen (ed.). Raisin production manual. UC Agricultural and Natural Resources Communications Services, Oakland, CA.

CLARY, C.D., STEINHAUER, R.E., FRISINGER, J.E. y PEFFER, T.E. 1990. Evaluation of machine-vs. hand-harvested Chardonnay. American Journal of Enology and Viticulture, 41: 176-181.

CONCHA, C.M., FIGUEROA, N.E., POBLETE, L.A., ONATE, F.A., SCHWAB, W. y FIGUEROA, C.R. 2013. Methyl jasmonate treatment induces changes in fruit ripening by modifying the expression of several ripening genes in Fragaria chiloensis fruit. Plant Physiology and Biochemistry, 70: 433-444.

COOMBE, B.G. y HALE, C.R. 1973. The hormone content of ripening of grape berries and the effects of growth substance treatments. Plant Physiology, 51: 629-634.

CREELMAN R. y MULLET J. 1995. Jasmonic acid distribution and action in plants: regulation during development and response to biotic and abiotic stress. Proceedings of the National Academy of Sciences of the United States of America, 92: 4114- 4119.

CREELMAN, R. y MULLET, J. 1997. Biosynthesis and action of jasmonates in plants. Annual Review of Plant Physiology Plant Molecluar Biology. 48:355-381.

DARIAS-MARTIN, J.J., RODRIQUEZ, O., DIAZ, E. y LAMUELA-RAVENTOS, R.M. 2000. Effect of skin contact on the antioxidant phenolics in white wine. Food Chemistry, 71: 483-487.

DE LA PEÑA MORENO, F., BLANCH, G.P., FLORES, G. y RUIZ DEL CASTILLO, M.L. 2010. Impact of postharvest methyl jasmonate treatment on the volatile composition and flavonol content of strawberries. Journal of the Science of Food and Agriculture, 90: 989-994.

DELGADO, R., GALLEGOS, J.I., MARTíN, P. y GONZÁLEZ, M.R. 2004. Influence of $A B A$ and ethephon treatments on fruit composition of 'Tempranillo' grapevines. Acta Horticulturae, 640: 321-326. 
DELGADO A.E., SUN, D.W. y RUBIOLO, A.C. 2005. Thermal physical properties of foods. Thermal Food Processing: New Technologies and Quality Issues, 150: 334.

DEMOLE, E., LEDERER, E. y MERCIER, D. 1962. Isolement et determination de la structure du jasmonate de methyle, constituant odorant caractéristique de l'essence de jasmin. Helvetica Chimica Acta, 45: 675-685.

DENNEY, J.O y MARTIN, G.C. 1994. Ethephon tissue penetration and harvest effectiveness in olive as a function of solution $\mathrm{pH}$, application time, and BA or NAA addition. Journal of the American Society for Horticultural Science, 119: 1185-1192.

DOWNTON, W.J.S. y LOVEYS, B.R. 1978. Compositional changes during grape berry development in relation to abscisic-acid and salinity. Australian Journal of Plant Physiology, 5: 415-423

EDGERTON, L.J. y GREENHALGH, W.J. 1969. Regulation of growth, flowering and fruit abscission with 2-chloroethanephosphonic acid. Journal of the American Society for Horticultural Science, 94: 11-13.

EL-ZEFTAWI, B.M. 1982. Effects of ethephon on clusters loosening and berry composition of four wine cultivars. Journal Horticulture Science, 57: 457-463.

ELFVING, D.C., AUVIL, T.D., CASTILLO, F., DRAKE, S.R., KUNZEL, H., KUPFERMAN, E.M., LORENZ, B., MCFERSON,J.R, REED, A.N., SATER,C., SCHMIDT, T.R. y VISSER, D.B. 2009. Effects of preharvest application of ethephon and 1-MCP to Bing Sweet cherry on fruit removal force and fruit quality. Journal of the American Pomological Society, 63: 84-100.

ESCUDERO, A., ASENSIO, E., CACHO, J. y FERREIRA, V. 2002. Sensory and chemical changes of young white wines stored under oxygen. An assessment of the role played by aldehydes and some other important odorants. Food Chemistry, 77: 325-331.

EYNARD, I. 1970. The effects of 2-chloroethylphosohonic acid sprays on Vitis vinifera related to mechanical harvesting. Proceeding $10^{\circ}$ of the conference on $\mathrm{Br}$. Weed Control, 275-278.

EYNARD, I. 1975. Effects of preharvest application of TH6241 and CEPA on Vitis vinifera. Vitis, 13: 303-307.

FAN, X. y MATTHEIS, J.P. 1999. Impact of 1-methylcyclopropene and methyl jasmonate on apple volatile production. Journal of Agricultural and Food Chemistry, 47: 2847-2853. 
FAN, X., MATTHEIS, J.P y FELLMAN, J.K. 1998. Responses of apples to postharvest jasmonate treatments. Journal of the American Society for Horticultural Science, 123: 421-425.

FAN, X., MATTHEIS, J. P., FELLMAN, J.K. y PATTERSON, M.E. 1997. Effect of Methyl Jasmonate on Ethylene and Volatile Production by Summer red Apples Depends on Fruit Developmental Stage. Journal Agricultural Food Chemistry, 45: 208-211.

FEBO, P., PERI, G. Y PIPITONE, F. 1997. Un Impianto per inibire il processo di ossidazione durante la raccolta meccanica delle uve bianche, Atti del VI Convegno Nazionale di Ingegneria Agraria, Ancona 11-12 settembre 3, 509513.

FERNANDEZ-ZURBANO, P., FERREIRA, V., ESCUDERO, A. y CACHO, J. 1998. Role of hydroxycinnamic acids and flavanols in the oxidation and browning of white wines. Journal of agricultural and food chemistry, 46: 4937- 4944.

FERNÁNDEZ-ZURBANO, P., FERREIRA, V., PEÑA, C., ESCUDERO, A., SERRANO, F. Y CACHO, J. 1995. Prediction of oxidative browning in white wines as a function of their chemical composition. Journal of Agricultural and Food Chemistry, 43: 2813- 2817.

FERREIRA, V., ESCUDREO, A., FERNÁNDEZ, P. Y CACHO, J.F. 1997. Changes in the profile of volatile compounds in wines stored under oxygen and their relationship with the browning process. Zeitschrift für LebensmittelUntersuchung und -Forschung A, European Food Research and Technology, 205: 392-396.

FIDELIBUS, M. y CATHLINE K. 2010. Dose and time dependent effects of methyl jasmonate on abscission of grapes. Proceeding XI IS on Plant Biorregulators in fruit production. Acta Horticulturae, 884: 725-728.

FIDELIBUS M.W., CATHLINE K.A. y BURNS J.K. 2007a. Potential abscission agents for raisin, table and wine grapes. HortScience, 42:1626-1630.

FIDELIBUS, M.W., CHRISTENSEN, L.P., KATAYAMA, D.G. y RAMMING, D.W. 2008. Earlyripening grapevine cultivars for dry-on-vine raisins on an open-gable trellis. HortTechnology, 18: 740-745.

FIDELIBUS, M.W., VASQUEZ, S.J. y CATHLINE, K.A. 2007b. Canopy separation and defoliation do not improve the dry-on-vine raisin-making method for 'Thompson Seedless' grapevines on traditional trellises. Journal American Pomological Society, 61: 61-70. 
FUNG, R.W.M., WANG, C.Y., SMITH, D.L. ,GROSS, K.C. y TIAN, M.S. 2004. MeSA and MeJA increase steady-state transcript levels of alternative oxidase and resistance against chilling injury in sweet peppers (Capsicum annuum L.). Plant science, 166: 711-719.

GALLEGOS, J.I., GONZALEZ, R., GONZALEZ, M.R. y MARTIN, P. 2006. Changes in composition and colour development of 'Tempranillo' grapes during ripening induced by ethephon treatments at veraison. Acta Horticulturae, 727: 505-512.

GHASEMI PIRBALOUTI, A., SAJJADI, EBRAHIM, S. y PARANG, K. 2014. A Review (research and patents) on jasmonic acid and its derivates. Archiv der Pharmazie, 347: 229-239.

GHASEMNEZHAD, M. y JAVAHERDASHTI, M. 2008. Effect of methyl jasmonate treatment on antioxidant capacity, internal quality and postharvest life of raspberry fruit. Journal of Environmental Science, 6: 73-78.

GIOVANNONI, J.J. 2004. Genetic regulation of fruit development and ripening. The Plant Cell, 16: 170-180.

GÓMEZ PLAZA, M.E, MESTRE ORTUÑO, L., RUIZ GARCÍA, Y., FERNÁNDEZ FERNÁNDEZ, J.I. y LÓPEZ ROCA, J.M. 2012. Effect of Benzothiadiazole and Methyl Jasmonate on the Volatile Compound Composition of Vitis vinifera $L$. Monastrell Grapes and Wines. American Journal of Enology and Viticulture, 63: 394-401.

GONZALEZ-HERRANZ, R., CATHLINE, K.A., FIDELIBUS, M.W. y BURNS, J.K. 2009. Potential of methyl jasmonate as a harvest aid for 'Thompson Seedless' grapes: concentration and time needed for consistent berry loosening. Hortscience, 44: 1330-1333.

GOZZO, F. 2003. Systemic acquired resistance in crop protection: From nature to a chemical approach. Journal of Agricultural and Food Chemistry, 51: 4487-4503.

GUERZONI, M., ZIRONI, E.R., INTRIERI, C. y MAGNANINI, E. 1981. Stabilisation of White wine by early hyperoxidation of must. Food technology Aust. 33, 442-446.

HALE, C.R., COOMBE, B.G. y HAWKER, J.S. 1970. Effects of ethylene and 2chloroethylphosphonic acid on the ripening of grapes. Plant Physiology, 45: 620-623.

HAMBERG, M. y GARDNER P. 1992. Oxylipin pathway to jasmonate: biochemistry and biological significance. Biochimica et Biophysica Acta 1165:1-18. 
HARTMOND, U., YUAN, R., BURNS, J. K., GRANT, A., y KENDER, W. J. 2000. Citrus fruit abscission induced by methyl-jasmonate. Journal of the American Society for Horticultural Science, 125: 547-552.

HEDBERG, P.R. y GOODWIN P.B. 1980. Factors affecting natural and ethephoninduced grape berry abscission. American Journal of Enology and Viticulture, 31: 109-113.

HENDERSON, J. y OSBORNE, D.J. 1994. Inter-tissue signalling during the two-phase abscission in oil palm fruit. Journal of Experimental Botany, 45: 943-951.

HIDALGO, L. 1993. Tratado de viticultura general. Madrid. Editorial Mundi-Prensa. España.

HILT, C. y BESSIS, R. 2003. Abscission of grapevine fruitlets in relation to ethylene biosynthesis. Vitis, 42: 1-3.

HIRSCHFELD, G., y S. LAVEE. 1980. Control of vegetative growth of grapevine shoots by ethylene-releasing substances. Conditions and sites of action. Vitis, 19:30816.

INTRIERI, C. 2013. Research and Innovation for Full Mechanization of Italian Vineyards at Bologna University . Proc 1 st. IW on Vineyard Mechanization and grape and wine quality. Acta Horticulturae, 978: 151-168.

INTRIERI, C., FILIPPETTI, I., ALLEGRO, G., CENTINARI, M. y PONI, S. 2008 Early defoliation (hand vs mechanical) for improved crop control and grape composition in Sangiovese (Vitis vinifera L.). Australian Journal of Grape and Wine Research, 14: 25-32.

INTRIERI, C. y PONI, S. 1990. A new integrated approach between training system and mechanical equipment for full mechanization of quality vineyards. p.35-50. In: P.J. Williams, D.M. Davidson y T.H. Lee (eds.), In: Proceeding $7^{\circ}$ Australian Wine Industry Technical Conference, Adelaide, Australia.

INTRIERI C. y PONI S. 1995. Integrated Evolution of Trellis Training Systems and Machines to Improve Grape Quality and Vintage Quality of Mechanized Italian Vineyards. American Journal of Enology and Viticulture, 46:116-127.

JANKIEWICZ, L.S. 1985. Mechanism of abscission of leaves and reproductive parts of plants a model. Acta Societatis Botanicorum Poloniae, 54: 285-322.

JIN, P., ZHENG, Y.H., GAO, H.Y., CHENG, C.M., CHEN, W.X. y CHEN, H.J. 2006. Effects of methyl jasmonate treatment on fruit decay and quality in peaches during storage at ambient temperature. Acta Horticulturae, 712: 711-716.

JUSTIA, 2014. Disponible en: http://patents.justia.com/patent/8435929. Fecha de consulta: 17/11/2014. 
KENDER, W.J., HARTMOND, U., BURNS, J. K., YUAN, R. y POZO, L. 2001. Methyl jasmonate and $\mathrm{CMN}$-pyrazole applied alone and in combination can cause mature. Scientia Horticulturae, 88: 107-120.

KHAN, A.S. y SINGH, Z. 2007. Methyl jasmonate promotes fruit ripening and improves fruit quality in Japanese plum. Journal of Horticultural Science and Biotechnology, 82: 695-706.

KHAN, A.S. y SINGH, Z. 2010. Pre-harvest application of putrescine influences japanese plum fruit ripening and quality. Food Science and Technology International, 16: 53-64.

KIM, J., B. DOTSON, C. REY, J. LINDSEY, A.B. BLEECKER, B.M. BINDER, y S.E. PATTERSON. 2013. New clothes for the jasmonic acid receptor COl1: Delayed abscission, meristem arrest and apical dominance. PLoS One 8: e60505.

KODA, Y. 1997. Posible involvemente of jasmonates in various morphogenetic events. Physiolpgia Plantarum, 100: 639-646

KONDO, S. y FUKUDA, K. 2001, Changes of jasmonates in grape berries and their possible roles in fruit development. Scientia Horticulturae, 91: 275-288.

KONDO, S., SETHA, S., RUDELL, D.R., BUCHANAN, D.A. y MATTHEIS. J.P. 2005. Aroma volatile biosynthesis in apple affected by 1-MCP and methyl jasmonate. Postharvest Biology and Technology, 36: 61-68.

KONDO, S. y TAKANO, Y. 2000.Cell wall metabolism and induction of ripening capacity in "La France" pears as influenced by 2,4.DP. Journal of the American Society for Horticultural Science, 125: 242-247.

KONDO, S., TOMIYAMA, A. ySETO, H. 2000. Changes of endogenous jasmonic acid and methyl jasmonate in apples and sweet cherries during fruit development. Journal of American Society of Horticultural Science, 125: 282-287.

KONDO, S., YAMADA, H. y SETHA, S. 2007. Effects of jasmonates differed at fruit ripening stages on 1-aminocyclopropane-1-carboxylate (ACC) synthase and ACC oxidase gene expression in pears. Journal of the American Society for Horticultural Science, 132: 120-125.

KOU, L., LUO, Y., WU, D. y LIU, X. 2007. Effects on mild heat treatment on microbiological growth and product quality of packaged fresh cut table grapes. Journal of Food Science, 72: 567-573.

LALEL, H. J. D., SINGH, Z. y TAN, S. C. 2003.The role of methyl jasmonate in mango ripening and biosynthesis of aroma volatile compounds. Journal of Horticultural Science and Biotechnology, 78: 470-484. 
LAVEE, S. 1987. Usefulness of growth regulators for controlling vine growth and improving grape quality in intensive vineyard. Acta Horticultuae, 206: 88-108.

LI, D. P., XU, Y. F., SUN, L. P., LIU, L. X., HU, X. L., LI,D.Q. y SHU, H. R. 2006. Salicylic acid, ethephon, and methyl jasmonate enhance ester regeneration in 1-MCP-treated apple fruit after long-term cold storage. Journal of Agricultural and Food Chemistry, 54: 3887-3895.

LI, H., GUO, A., y WANG, H. 2008. Mechanisms of oxidative browning of wine. Food Chemistry, 108: 1-13.

LI, H., WANG, H., YUAN, C. y WANG, S. 2005. Wine chemistry. Beijing: Scientific Publishing Company.

LIN, Z., ZHONG, S. y GRIERSON, D. 2009. Recent andvances in ethylene research. Jorunal of Experimental Botany, 60: 3311-3336.

LÓPEZ-TOLEDANO, A., MAYEN, M., MERIDA, J. y MEDINA, M. 2002. Yeast induced inhibition of $(+)$-catechin and (-)-epicatechin degradation in model solutions. Journal of Agricultural and Food Chemistry, 50: 1631-1635.

LUND, C. M.,THOMPSON, M. K., BENKWITZ, F., WOHLER, M. W., TRIGGS, C. M., GARDNER, R., HEYMANN, H. y NICOLAU, L. 2009. New Zealand Sauvignon blanc distinct flavor characteristics: sensory, chemical and consumer aspects. American Journal of Enology and. Viticulture, 60: 1-12.

MACHEIX, J.J., SAPIS, J.C. y FLEURIET, A. 1991. Phenolic compounds and polyphenol oxidase in relation to browning in grapes and wines. Critical Reviews in Food Science and Nutrition, 30: 441-486.

MAGRAMA, 2015. Registro de máquinas vendimiadoras [en línea]. Disponible en: http://www.magrama.gob.es/ Fecha de consulta: 04/03/2015.

MAILHAC, N. y CHERVIN, C. 2006. Ethylene and grape berry ripening. Stewart Postharvest Review 2, 1-5.

MAINLAND, C. M. y NESBITT, W. B. 1974. The effects of ethephon on detachment and stem scar characterisitics of 'Magnolia' Vitis rotundifolia grapes. HortScience, 9: 304.

MAINLAND, C.M., NESBITT, W.B. y MILHOLLAND, R.D. 1977. The effect of ethephon on detachment and keeping quality of 'Carlos', 'Magnolia', and 'Noble' muscadine grapes (Vitis rotundifolia Michx.). Proceeding 4th Annual Meeting Plant Growth Regulation. Working Group 4: 244-245.

MALLADI, A., VASHISTH, T., y JOHNSON, L.K. 2012. Ethephon and methyl jasmonate affect fruit detachment in rabbiteye and souther highbush blueberry. HortScience, 47: 1745-1749. 
MANOJLOVIĆ, R., MITROVIĆ, D. y SAVIĆ, S. 2009. Tehničko-tehnološki, eksploatacioni i tehnoekonomski pokazatelji rada kombajna za berbu grožđa. Poljoprivredna Tehnika, 34: 77-83.

MANOJLOVIĆ, R., MITROVIĆ, D., BULATOVIĆ, I., UROŠEVIĆ, M. AND ŽIVKOVIĆ, M. 2011. Eksploatacioni parametri vučenog kombajna za berbu grožđa "Volentieri VG 2000/2TA". Poljoprivredna Tehnika, 3: 99-108.

MARKS, A. C. 1990. The use of ascorbic acid to enhance sparkling wine oxidative stability. Tesis doctoral, University of Arkansas, AR, United States.

MARTIN, M.N, COHEN, J.D y SAFTNER, R.A. 1995. A new 1-aminocyclopropane-1carboxylic acid conjugating activity in tomato fruit. Plant Physiology, 109: 917926.

MAYNARD, J.A. y SWAN, J.M. 1963. Organophosphorus compounds. I. 2chloroalkylphosphonic acid as phosphorylating agents. Australian Journal of Chemistry, 16: 596-608.

MAZZA, G. Anthocyanins in grapes and grape products. 1995. Critical Reviews in Food Science and Nutrition, 35: 341-371.

MEIR, S., PHILOSOPH-HADAS, S., LURIE, S., DROBY, S., AKERMAN, M., ZAUBERMAN, G., SHAPIRO, B., COHEN, E. y FUCHS, Y.1996. Reduction of chilling injury in stored avocado, grapefruit, and bell pepper by methyl jasmonate. Canadian Journal of Botany, 74: 870-874

MEMELINK J, VERPOORTE R, y KIJNE J. 2001. ORCAnization of jasmonateresponsive gene expression in alkaloid metabolism. Trends in Plant Science, 6: 212-219.

MENESATTI, P., PAGLIA, G., SOlAINI, S., NICIARELLI, I., y D'ANDREA, S. 2005. Mechanical damage to citrus fruit. InformatoreAgrari, 61: 53-55.

MEYER, J. 1969. Effect of Fruit Cane Severance of Grapevines on Must and Wine Yield and Composition. American Journal of Enology and Viticulture, 20: 108117.

MEYER, A., MIERSCH, O., BÜtTNER, C., DATHE, W. y SEMBDNER, G. 1984. Occurrence of the plant growth regulator jasmonic acid in plants. Journal of Plant Growth Regulation, 3: 1-8.

MORRIS J.R. 1998. Factors influencing grape juice quality. Hort-Technology, 8: 471478.

MORRIS, J.R. y CAWTHON, D.L. 1981. Effects of ethephon on maturation and postharvest quality of Concord Grapes. Journal American Society of Horticultural Sciences, 106: 293-295. 
MORRIS, J.R. y CAWTHON, D.L. 1982a. Ethephon as a harvesting aid for Concord grapes. Arkansas Farm research, 31: 15.

MORRIS, J.R. y CAWTHON, D.L. 1982b.Effectos of ethephon on maturation and quality of Concord grapes. Arkansas Farm Research, 31: 6.

MORTENSEN, J.A.1980. Effects of ethephon on ease of harvest of Muscadine grapes. Proceeding of the Florida State Horticultural Society, 93:143-145.

MUKKUN, L. y SINGH, Z. 2009. Methyl jasmonate plays a role in fruit ripening of 'Pajaro' strawberry through stimulation of ethylene biosynthesis. Scientia Horticulturae, 123: 5-10.

MULLINS, M.G., BOUQUET, A., y WILLIAMS, L.E. 1992. Biology of the grapevine. Cambridge University Press, Cambridge, Reino Unido.

NAGEL, C.W. y GRABER W.R. 1988. Effect of must oxidation on quality of white wines. American Journal of Enology and Viticulture, 39: 1-4.

NIR, G. y LAVEE, S. 1981. Persistence, uptake and translocation of ['4C] ethephon (2chloroethyl phosphonic acid) in Perlette and Cardinal grapevines. Australian Journal Plant Physiology, 8: 57-66.

OLIVEIRA, C.M., SILVA, A.C., DE SILVA, V., y SILVA, A.M.S. 2011. Oxidation mechanisms occurring in wines. Food Research International, 44: 1115-1126.

ORTIZ C., BLASCO, J., BALASCH, S. y TORREGROSA, A. 2011. Shock absorbing surfaces for collecting fruit during the mechanical harvesting of citrus. Biosystems Engineering, 110: 2-9.

ORTIZ-CAÑAVETE J., GIL, J. y RUIZ-ALTISENT, M.1990. Mecanización de la recolección de fruta en España. Información Tecnológica, 6: 82-96.

OSBORNE, DJ. 1989. Abscission. CRC Critical Reviews in Plant Sciences, 8: 103-129.

OUGH, C.S. 1969. Substances Extracted during Skin Contact with White Musts. I. General Wine Composition and Quality Changes with Contact Time. American Journal of Enology and Viticulture, 20: 93-100

OUGH, C.S. y BERG H.W. 1971. Simulated mechanical harvest and gondola-transport. Effect of temperature, atmosphere, and skin-contact on chemical and sensory qualities of white wines. American Journal of Enology and Viticulture, 22: 194198.

OUGHT, C.S, BERG, H.W., COFFELT, R.J. y COOKE, G.M. 1971. The effect on wine quality of simulated mechanical harvest and gondola transport of grapes. American Journal of Enology and Viticulture, 22: 65-70. 
ÖZTÜRK, B., ÖZKAN, Y. y YILDIZ, K. 2014.Methyl jasmonate treatments influence bioactive compounds and red peel color development of Braeburn apple. Turkish Journal of Agriculture and Forestry, 38: 688-699.

PAJIĆ M., UROŠEVIĆ, M., PAJIĆ, V., ŽIVKOVIĆ, M. y MITROVIĆ, D. 2013. The Influence of Training System and Vine Row Structure on Losses during Mechanized Harvest. Proc. 1st IW on Vineyard Mechanization and Grape and Wine Quality. Ed.: S. Poni. Acta Horticulturae, 978: 245-250.

PARI L. y PEZZI F. 2009. An Innovative System for Mechanical Harvested Grape Fruit Transport to avoid Must Chemical and Microbiological Modifications. International Commission of Agricultural and Biological Engineers, Section V. Conference "Technology and Management to Increase the Efficiency in Sustainable Agricultural Systems", Rosario, Argentina, 1-4 September 2009.

PATEL, P., HERBST-JOHNSTONE, M., LEE, S.A., GARDNER, R.C., WEAVER, R., NICOLAU, L., y KILMARTIN, P.A. 2010. Influence of juice pressing conditions on polyphenols, antioxidants and varietal aroma of Sauvignon Blanc microferments. Journal of Agrictural and Food Chemistry, 58: 7280-7288.

PEÑA-CORTES, H., BARRIOS, P., DORTA, F., POLANCO, V., SANCHEZ, C., SANCHEZ, E. y RAMIREZ, I. 2005. Involvement of jasmonic acid and derivatives in plant responses to pathogens and insects and in fruit ripening. Journal of Plant Growth Regulation, 23: 246-260.

PETERSON, J.R. y P.R. HEDBERG 1975: Some factors affecting the response of grapevines to ethephon. Scientia Horticulturae, 3: 275-283.

PEZZI, F., BALDUCCI, G., y PARI, L. 2013 . A New System to Preserve Quality of Grapes Harvested by Machine. Proc. 1st IW on Vineyard Mechanization and Grape and Wine Quality. Ed.: S. Poni. Acta Horticulturae, 978: 191-198.

PEZZI, F., BERARDINELLI, A., BORDINI, F., GIUNCHI, A. y RAGNI, L. 2005. Raccolta meccanica dell'uva:uno studio sulle correlazioni tra qualità del lavoro, condizioni operative e trasmissione delle vibrazioni alla pianta, Rivista di Ingegneria Agraria, 4: 25-34.

PEZZI, F. y BORDINI, F. 2006. La potatura meccanica del vigneto: aspetti tecnici, qualitativi ed economici di differenti livelli di meccanizzazione, Rivista di Ingegneria Agraria, 1: 55- 63

PEZZI, F. y CAPRARA, C. 2009. Mechanical grape harvesting: Investigation of the transmission of vibrations. Biosystems Engineering, 103: 281-286. 
PEZZI, F., CAPRARA, C. y BORDINI, F. 2008. Transmission of impacts during mechanical grape harvesting and transportation. Journal of Agricultural Engineer- Rivista di Ingegneria Agraria, 3: 43-48.

PIPITONE, F., PERI, G., CATANIA, P., CALAFATELlO, A.R. y VALLONE, M. 2003. Effetti della lunghezza dei filari sulla capacità operativa delle vendemmiatrici, L'Informatore Agrario, 2: 55-58.

POCOCK, K.F. y WATERS, E.J. 1998. The effect of mechanical harvesting and transport of grapes, and juice oxidation, on the protein stability of wines. Australian Journal of Grape and Wine Research, 4: 136-139.

POZO, L. y BURNS, J.K. 2009. Organ loss and yield impacts of 'Valencia' sweet orange in response to fruit abscission agents. HortScience, 44: 83-88.

POZO, L., YUAN, R., KOSTENYUK, I., ALFEREZ, F., ZHON, Y. y BURNS, J.K. 2004. Differential effects of 1-methylcyclopropene on citrus leaf and mature fruit abscission. Journal of American Society of Horticultural Science, 129: 473-478.

QUAGLINO, A., G. GAY, I. EYNARD, AND P. OCCELLI. 1981. Effetti di trattamenti estivi con ethephon sulla vite (Effects of summer ethephon treatments on grapevines). Atti Accad. Ital. Vite Vino, Siena 30:87-107 (1978/1979). From: Plant Growth Regulation Abstract, 1443 (1981).

REID, M.S. 1985. Ethylene and abscission. HortScience, 20: 45-50.

REINBOTHE. S, MOLLENHAUER, B. y REINBOTHE, C.1994. Jips and rips - the regulation of plant gene-expression by jasmonates in response to environmental cues and pathogens. Plant Cell, 6: 1197-1209.

REPKA, V., FISCHEROVA, I. y SILHAROVA, K. 2004. Methyl jasmonate is a potent elicitor of multiple defense responses in grapevine leaves and cell-suspension cultures. Biologia Plantarum, 48: 273-283.

RIZZUTI, A., AGUILERA-SAEZ, L.M., GALLO, V., CAFAGNA, I., MASTRORILLI, P., LATRONICO, M., PACIFICO, A., MATARRESE, A.M.S y FERRARA, G. 2015. On the use of Ethephon as abscising agent in cv. Crimson Seedless table grape production: Combination of Fruit Detachment Force, Fruit Drop and metabolomics. Food Chemistry, 171: 341-350.

ROBARDS, K., PRENZLER, P.D., TUCKE, G., SWATSITANG, P. y GLOVER, W. 1999. Phenolic compounds and their role in oxidative processes in fruits. Food Chemistry, 66: 401-436.

ROBERTS, J.A, WHITELAW, C.A., GONZÁLEZ-CARRANZA, Z.H. y MCMANUS, M. 2000. Cell separation processes in plants: models, mechanisms and manipulation. Annals of Botany 86, 223-235. 
ROHWER, C. L. y ERWIN, J. E. 2008. Horticultural applications of jasmonates: A review. Journal of Horticultural Science Biotechnology, 83: 283-304.

RUDELL, D.R., MATTHEIS, J.P, FAN, X. y FELLMAN, J.K. 2002. Methyl jasmonate enhances anthocyanin accumulation and modifies production of phenolics and pigments in "Fuji" apple fruit. Journal American Society Horticultural Sciences, 127: 435-441.

RUIZ-GARCÍA, Y., ROMERO-CASCALES, I., BAUTISTA-ORTÍN A. B., GIL-MUÑOZ, R., MARTÍNEZ-CUTILLAS, A y GÓMEZ-PLAZA, E. 2013. Increasing Bioactive Phenolic Compounds in Grapes: Response of Six Monastrell Grape Clones to Benzothiadiazole and Methyl Jasmonate Treatments. American Journal of Enology and Viticulture, 64: 459-465.

RUIZ-GARCÍA, Y., ROMERO-CASCALES, I., GIL-MUÑOZ R., FERNANDEZFERNANDEZ J. I., LÓPEZ-ROCA J. M, Y GÓMEZ-PLAZA, E. 2012. Improving grape phenolic content and wine chromatic characteristics through the use of two different elicitors: Methyl jasmonate versus benzothiadiazole. Journal Agriculture Food Chemistry, 60: 1283-1290.

SÁNCHEZ, D.S., BOLAND, M.A., y SUMNER,D. 2008. Sun-Maid growers of California. Review of Agricultural Economics, 30: 360-369.

SANIEWSKI, M., CZAPSKI, J. y NOWACKI, J. 1987a. Relationship between stimulatory effect of metyl jasmonate on ethylene and 1-aminocyclopropane-1carboxylic acid content in tomatoes. Biologia Plantarum, 29: 199-203.

SANIEWSKI, M., CZAPSKI, J., NOWACKI, J. Y LANGE, E. 1987b. The effect of methyl jasmonate on ethylene and 1-aminocyclopropane-1-carboxylic acid production in apple fruits. Biologia Plantarum, 29: 199-203.

SCHALLER, G.E. y KIEBER, J.J. 2002. Ethylene. In CR Somerville, EM Meyerowitz, eds, The Arabidopsis Book. American Society of Plant Biologists, Rockville, MD. United States of America.

SCHNEIDER, V. 2001. Microoxidation. I. Behaviour of red wines treated by overoxidation. Deutsche Weinmagazin. 3: 30-34.

SCHREINER, M. y HUYSKENS-KEIL, S. 2006. Phytochemicals in fruit and vegetables: Health promotion and postharvest elicitors. Critical Reviews in Plant Sciences, 25, 267-278.

SEMBDNER, G. y PARTHIER, B. 1993. The biochemistry and the physiological and molecular actions of jasmonates. Annual Review of Plant Physiology and Plant Molecular Biology, 44: 569-589. 
SEXTON, R. y ROBERTS, J.A.1982. Cell biology of abscission. Annual Review of Plant Physiology, 33: 133-162.

SILVA, A.C., GUEDES DE PINHO, P., RODRIGUES, P. y HOGG, T. 2002. Kinetics of oxidative degradation of white wines and how they are affected by selected technological parameters. Journal of Agricultural and Food Chemistry. 50: 5919-5924.

SIOUMIS, N., KALLITHRAKA, S., TSOUTSOURAS, E., MAKRIS, D. P. y KEFALAS, P. 2005. Browning development in white wines: Dependence on compositional parameters and impact on antioxidant characteristics. European Food Research and Technology, 220: 326-330.

STASWICK, P.E. y TIRYAKI I. 2004. The oxylipin signal jasmonic acid is activated by an enzyme that conjugates it to isoleucine in Arabidopsis. Plant Cell, 16: 21172127.

STERN, R.A, KIGEL, J., TOMER, E. y GAZIT, S. 1995. 'Mauritius' lychee fruit development and reduced abscission after treatment with the auxin 2,4,5-TP. Journal of the American Society for Horticultural Science, 120: 65-70.

STEWART, A.M., EDMISTEN, K.L. y WELLS, R. 2000. Boll openers in cotton: effectiveness and environmental infuences. Field Crop Research, 67: 83-90.

STUDER, H.E. 2000. Raisin harvest mechanization: A bit of history, p. 245-251. In: Christensen, L.P. (ed.). Raisin production manual. University of California, Agricultural and Natural Resources, Oakland, California.

SZYJEWICZ, E. y KLIEWER, W.M. 1982. Influence of temperature and ethephon concentration on growth and composition of Cabernet Sauvignon grapevines. Journal of Plant Growth Regulation, 1: 295-304.

SZYJEWICZ, E., ROSNER, N. y KLIENER, W.M. 1984. Etephon (2cloroethylphosphonic acid, Ethrel, CEPA) in Viticulture. American Journal of Enology and Viticulture, 35: 117-123.

TAIZ, L. y ZEIGER, E. 2006. Ethylene: the gaseous hormone. En: Fisiología Vegetal. Vol 2. $3^{\circ}$ Edición. Publicaciones Universidad Jaume I, Castellón de la Plana (España). Pags: 992-1028.

TAYLOR, J.E. y WHITELAW, C.A. 2001. Signals in abscission. New Phytologist, 151: 323-339.

TSUCHISAKA, A. Y THEOLOGIS, A. 2004. Heterodimeric interactions among the 1amino-cyclopropane-1-carboxylate synthase polypeptides encoded by the 
Arabidopsis gene family. Proceeding National Academy of Science United States of America, 101: 2275-2280.

UEDA, J. y KATO, J. 1982. Inhibition of cytokinin-induced plant growth by jasmonic acid and its methyl ester. Physiol Plant, 54: 249-252.

UEDA, J., MIYAMOTO, K. y KAMISAKA, S. 1995. Inhibition of the synthesis of cell wall polysaccharides in oat coleoptile segments by jasmonic acid: Relevance to its growth inhibition. Journal of Plant Growth Regulation, 14: 69-76.

UEDA, J., MIYAMOTO, K. y HASHIMOTO, M. 1996. Jasmonates promote abscission in bean petiole explants: Its Relationship to the metabolism of cell wall polisaccharides and celulase activity. Journal of Plant Growth Regulation, 15:189-195.

UZQUIZA L., GONZÁLEZ, R., GONZÁLEZ, M.R. y MARTÍN, P. 2014a: Aplicaciones de etefón y metil jasmonato para facilitar el desprendimiento del fruto en vides cv. Sauvignon blanc. En: Ayuga F., Masaguer A., Mariscal I., Villarroel M., RuizAltisent, M., Riquelme F. and Correa Hernando, E.C. (eds.). $7^{\circ}$ Congreso Ibérico de Agroingeniería y Ciencias Hortícolas. Madrid, p. 36.

UZQUIZA, L., GONZÁLEZ, R., GONZÁLEZ, M.R, MARCOS, J.M. y MARTíN, P. 2014b. Influencia de tratamientos prevendimia con etefón y metil jasmonato sobre el color del vino cv. Sauvignon blanc. I Jornada del grupo de viticultura y enología de la SECH. Retos actuales de I+D en Viticultura. 19 y 20 Noviembre 2014. Logroño, España.

VAN DE POEL, B. y VAN DER STRAETEN, D. 2014. 1-aminocyclopropane-1carboxylic acid (ACC) in plants: more than just the precursor of ethylene! Frontiers in Plant Science, 5: 1-11.

VAN LOON, L.C. 2000. Systemic induced resistance: In:Slusarenko AJ, Fraser RSS, Van Loon LC (eds).Mechanism of resistance to plant disease. Kluwer, Dordrecht, pp 521-574.

VICK, B.A. y ZIMMERMAN, D.C. 1984. Biosynthesis of jasmonic acid by several plant species. Plant Physiology, 75: 458-461.

VRHOVSEK, U. 1998. Extraction of hydroxycinnamoyltartaric acids from berries of different grape varieties. Journal of Agricultural and Food Chemistry, 46: 42034208.

WANG, C.Y. 2003. Maintaining postharvest quality of raspberries with natural volatile compounds. International Journal of Food Science and Technology, 38: 869875.

WANG, Z. 1990. Food enzymology. China Light Industry Press. Beijing. 
WANG, K.L., LI, H., y ECKER, J.R. 2002 Ethylene biosynthesis and signaling networks. Plant cell, 14 (Sppl): 131- 151.

WANG, S.Y. y ZHENG, W. 2005. Preharvest application of methyl jasmonate increases fruit quality and antioxidant capacity in raspberries. International Journal of Food Science and Technology, 40: 187-195.

WASTERNACK, C. 2007. Jasmonates: an update on biosynthesis, signal transduction and action in plant stress response, growth and development. Annals of botany 100: 681-697.

WASTERNACK, C. y HAUSE, B. 2013. Jasmonates: biosynthesis, perception, signal transduction and action in plant stress response, growth and development. An update to the 2007 review in Annals of Botany Annals of Botany, 111: 10211058.

WITTENBACH, V.A. y BUKOVAC, M.J. 1974 Cherry fruit abscission: evidence of time of initiation and involvement of ethylene. Plant Physiology, 54: 494-498.

WITTENBACH, V.A. y BUKOVAC, M.J. 1975. Cherry fruit abscission: peroxidase activity in the abscission zone in relation to separation. Journal of American Society of Horticultural Science, 100: 387-391.

YANG, S.F. y HOFFMAN, N.E. 1984. Ethylene biosynthesis and its regulation in higher plants. Annual Review Plant Physiology, 35: 155-189.

YOON, G.M. y KIEBER, J.J. 2013. 1-Aminocyclopropane-1-carboxylic acid as a signaling molecule in plants. AoBPlants, 5: plt017.

YOUSEFI, Z., ALMASSI, M., ZEINANLOO, A.A, GHOLIYAN, A. y KHIAVE, M. 2012. Effect of ethephon on time of olive oil (cv. Zard) harvesting. Food, Agriculture and Environment, 10: 516-519. 
